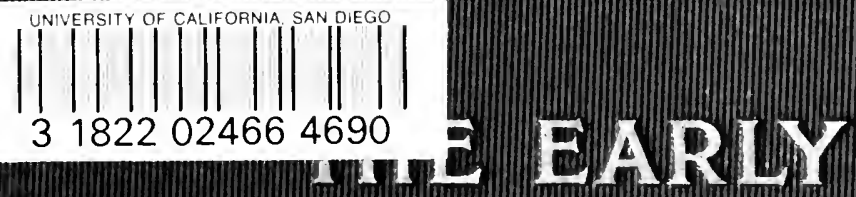 \\ SCOTTISH CHURCH \\ ITS DOCTRINE AND DISCIPLINE
}

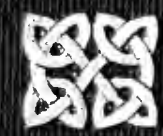




\section{Digitized by the Internet Archive in 2007 with funding from Microsoft Corporation}




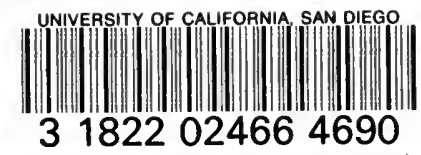

$\begin{array}{ll}12 & 37 \quad 48\end{array}$

\section{Social Sciences \& Humanities Library}

University of California, San Diego

Please Note: This item is subject to recall.

\section{Date Due}

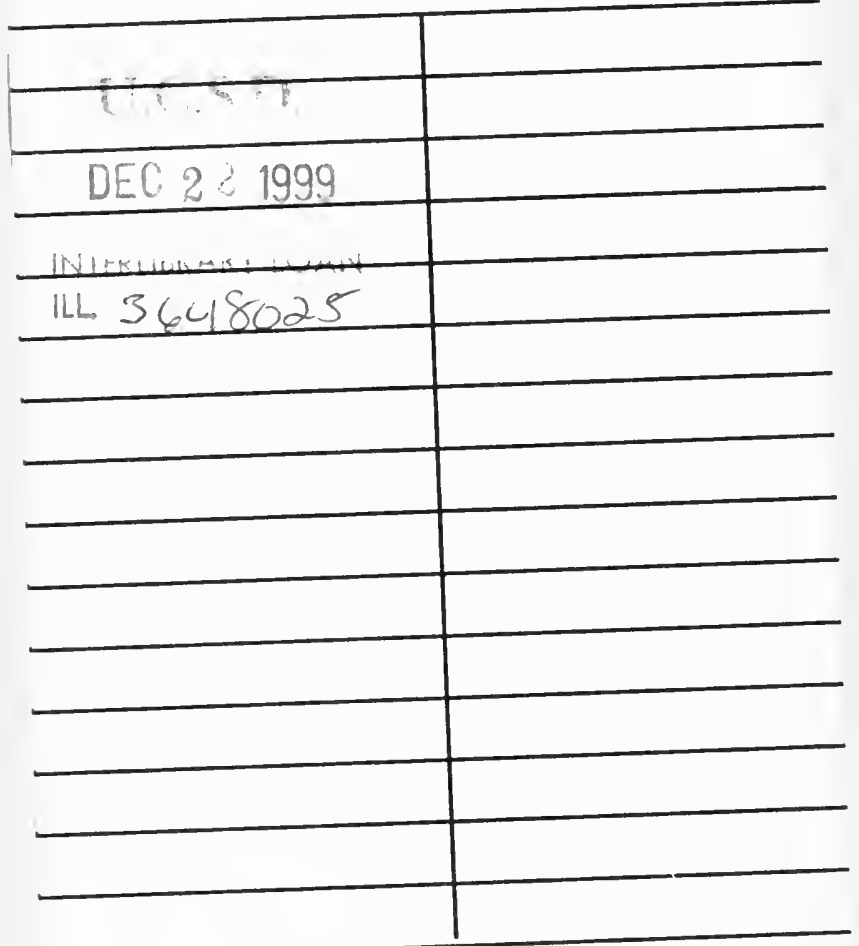



THE EARLY SCOTTISH CHURCH

ITS DOCTRINE AND DISCIPLINE 



\title{
THE EARLY
}

\section{SCOTTISH CHURCH}

\section{Its Doctrine and Discipline}

\author{
BY \\ DOM COLUMBA EDMONDS
}

MONK OF FORT AUGUSTUS

WITH A PREFACE BY THE

Right Reverend ÆNEAS CHIShOLM, LL.D.

BISHOP OF ABERDEEN

\section{SANDS \& CO.}

EDINBURGH: 13 BANK STREET

LONDON : 23 BEDFORD STREET, STRAND

1906 
Nihil obstat

D. KENTIGERNUS MILNE, O.S.B. Censor Deputatus

Die 4 a Augusti 1905

Imprimatur

* Jacobus augustinus

Archiep. S. Andrea et Edimburgen.

Die 28a Angusti 1905 


\section{BEATO PETRO}

AGNORUM OVIUMQUE PASTORI 


\section{CONTENTS}

Preface by Bishop Chisholm . . . . xi

Author's Preface . . . . . . $\mathrm{xv}$

LIST OF WORKS QUOTED OR CONSULTED . . . Xvii

Dates of Principal Events . . . . . $\mathrm{xx}$

\section{PART I.-PAPAL CLAIMS}

CEAPTER

I. INTRODUCTORY $\quad . \quad$.

11. Need of Papal Supremacy . . . . 14

iil. Scriptural Testimony to St Peter's SuPREMACY . . . . . . . 17

iv. Supremacy of St Peter in the Apostolic Age 24

v. Objections to St Peter's Supremacy , . 27

vi. Patristic Testimony to St Peter's Supremacy 31

vit. St Peter First Bishop of Rome. . . 36

vili. Supremacy of St Peter's Successors . . 40

ix. Testimony of History and of the Fathers to Papal Supremacy $\quad$. $\quad$. $\quad$. 43

X. Objections to Papal Supremacy . . . 47

xi. Exercise of Papal Supremacy in Early Times 53

xil. The Fathers and Papal Supremacy • • 59

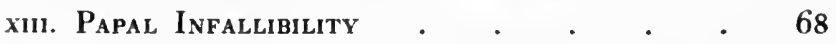

xiv. Scripture and Papal Infallibility . • 76 vii 
xv. The Witness of Tradition to Papal InfalLIBILITY .

xvi. Objections to Papal Infallibility . $\quad 84$

xviI. The Pope's Temporal Power . . . 87

\section{PART II._CELTIC CHRISTIANITY}

1. Early Migsions fron Rome . . . . 93

II. British Bishops in Papal Councils . 98

III. St Ninian's Mission . . . . . . 102

iv. Papal Missions from Gaul . . . . 108

v. Mission of St Palladius . . . . . 113

vi. Roman Mission of St Patrick . . . 117

vir. Evidence for St Patrick's Roman Mission . 129

vili. The Irish Churcil and Papal Supremacy - 137

ix. Apostolate of St Kentigern . . . 144

x. Apostolate of St Columba . . . . 148

xi. St Columbanus and the Pope . . . 160

\section{PAR'T III.-DOCTRINE AND DISCIPLINE}

I. Unity AND Uniformity * . . . 169

II. The Paschal Controversy • . . . 173

III. St Cummian's Paschal Epistle . . . 183

iv. The Controversy in Norti Ireland and Iona 189

v. St Aidan in Nonthumbria . . . . . 193

vi. The Wiitby Conference . . . . 197

vis. St Adamnan. 


\section{PART IV.-LITURGY AND RITUAL OBSERVANCES}

1. Origins of the Liturgy . . . . 217

11. Celitic Liturgy and Papal Supremacy • 222

iit. The Language of the Liturgy . . . 231

iv. Celtic Pilgrimages to Rome . . . 234

v. The Cultus of our Lady . . . . . 240

vi. Veneration of Angels and Saints . • 252

viI. Holy Reuics . . . . . . 256

vili. SAcred Images . . . . . . . 261

ix. Prayer for the Dead . . . . . 263

x. The Holy Eucharist . . . . . 265

xi. Communion under one Kind, and other

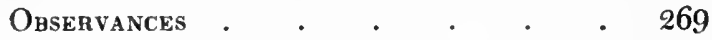
xiI. Confession . . . . . . . . . 276

xili. Penance and Fasting . . . . . $\quad$. 279

xiv. Confirmation $\quad . \quad$. $\quad . \quad$. $\quad$. 282

xv. Extreme Unction . . . . . 284

Xvi. Clerical Celibacy a . . . . . 286

xvir. The Medieval, Church . . . . 293

INDEX . . . . . . . . . . . 299 



\section{PRE FACE}

Prejudices are difficult to overcome; traditions arising from them die hard. The Church in Scotland as it existed in the sixth century has been the source and centre of many of them. They have been repeated and confuted, and repeated and confuted again and again. We welcome the following work by Father Columba Edmonds, O.S.B., of Fort Augustus-not so much, perhaps, because he tells us anything new upon the interesting question of debate, whether the Columban Church acknowledged the supremacy of Rome or not, but because he brings together the contentions of the various Churches which at the present time claim this venerable one as their own, and puts the facts and the arguments for and against in a concise and, at the same time, a comprehensive form.

Father Columba may justly be regarded as an authority on this subject. He has appeared more than once in controversy with xi 
the doughty champions of the Protestant contention. Not Catholics alone bore testimony that the Monk of Fort Augustus had successfully vindicated the good Catholic name and faith of the monks of Iona. His present work will appeal to a wider public, and we feel confident that it will dispel many prejudices, and overturn many wrong traditions, encircling the Celtic Church.

While we can sympathise with the natural feeling and aspirations of Presbyterians and Episcopalians in their wish to be considered connected in some way or other with so venerable and remote an ancestry, we cannot, in the best interests of truth and religion, and for their own good as well, allow the faith of our Fathers to be represented as different from the faith and teaching which prevailed throughout Europe in the early centuries. I remember when calling upon a friend, a Wesleyan clergyman, and looking over his bookshelves, I expressed my pleasure in seeing the works of St John Chrysostom among his books. "Why not?" he said. "I find great assistance from him when preparing my sermons: he was a true 
Evangelical." I pointed out certain passages in the writings of the Saint: "God bless me," he exclaimed, "I had no idea he was a Romanist!"

\section{正NEAS,}

Bishop of Aberdeen.

21 st August 1905. 



\section{AUTHOR'S PREFACE}

The use of the terms "Scottish Church," "Celtic Church," and "Columban Church" may be misleading to readers who are familiar with the existence of national Churches - such as the Church of Scotland, the Anglican Church, etc. The terms are used in the title of this work and in the following pages to designate the ancient Catholics of Ireland and Scotland, who were in communion, through a common faith, with the rest of Christendom. Bede speaks of no independent Church in Scotland, but refers to the Christians of Caledonia as those who received the "Faith of Christ" through the apostolate of Columba. ${ }^{1}$ On account of that apostolate having taken its origin from Ireland, special attention will be paid to the belief and practice of the Church founded by St Patrick, since by this alone can a true estimate be formed of the doctrine and discipline of Iona. The Roman char-

1 " Ad fiden Christi convertit," Beda, "Hist. Eccl." Lib. III. c. iv. 
acter of the Irish Church has been sufficiently demonstrated by Dr J. B. Bury, Regius Professor of Modern History of the University of Cambridge, in his latest contribution to Patrician literature, "The Life of St Patrick and his Place in History." 


\section{LIST OF WORKS QUOTED OR CONSULTED}

Adamnax, St. "Vita S. Columbæ." Edited by Rev. Wm. Reeves, D.D. Edinburgh, 1874.

Allies, T. W. "St Peter, his Name and Office." London, 1895. Allanat, Charles F. B. "Cathedra Petri." London, 1879.

Anderidox, Rev. W. H., S.J. "Britain's Early Faith." London. Barnes, Rt. Rev. A. S., M.A. "St Peter in Rome." London, 1900.

Barry, William, D.D. "The Papal Monarchy" (Story of the Nations Series). London, 1902.

Bellesheim, A., D.D. "History of the Catholic Church of Scotland." Translated by Rev. Sir D. O. Hunter Blair, O.S.B. Edinburgh.

Bright, William, D.D. "Early English Church History." Oxford.

BRIDQETT, Rev. T. E., C.SS.R. " History of the Holy Eucharist in Great Britain." London, 1881.

Brows, P. Huмe, M.A., LL.D. "History of Scotland." Cambridge, 1902.

Bury, J. B., M.A. "The Life of St Patrick, and his Place in History." London, 1905.

Bute, Johy, Third Marqdess of, K.T., LL.D. “ Essays on Home Subjects." Paisley, 1904.

Chapman, Dom Johs, O.S.B. "Bishop Gore and the Catholic Claims." London, 1905.

Colgan, Rev. Johr, O.S.F. "Acta SS." Louvain.

Conway, Rev. B. L. "The Question-Box Answers." New York, 1903.

Cusack, M. F. "Life of St Patrick." London, 1877.

Döllinger, Rev. J. J. IG., D.D. "A History of the Church." Translated by the Rev. E. Cox., D.D. London, 1840.

Dowden, Johs, D.D., Bishop of Edinburgh. "The Celtic Church in Scotland." London, 1894.

Duchesne, L'Abie L. “Origines de Culte Chrétien.” Paris, 1898.

Duchesne, Mgr. L. “Christian Worship." London, 1903.

Freeland, Rev. Jonn. "The First Six Centuries, and the Church of England." Dublin Review, April, 1905.

Fowler, J. T., M.A., D.C.I. "Adamnani Vita S. Columbæ." Oxford, 1894.

xvii 
Gasquet, Abrow, F. A., O.S.B., D.D. "A Short History of the Catholic Church in England." London, 1903.

Gibbons, James, Cardinal. "The Faith of our Fathers." Baltimore, 1897.

Gore, Rev. Chanles, M.A. "Roman Catholic Claims." London, 1890.

GradWell, MGr. "Succat." London, 1891.

Haddan and Stubbs. "Councils and Ecclesiastical Documents Relating to Great Britain and Ireland." Oxford.

Healy, Most Rev. John, D.D., LL.D. "Insula Sanctorum et Doctorum, or Ireland's Ancient Schools and Scholars." Dublin, 1890.

Hedley, Rt. Rev. J. C., O.S.B. "The Light of Life." London, 1899.

HetTinger, Very Rev. F. "Supremacy of the Apostolic See." London.

Hogan, Rev. Edmund, S.J. “Documenta de S. Patricio ex Libro Armachano." Analecta Bollandiniana, vol, i. Brussels, 1882.

Hunter, Rev. Sxlvester, S.J. "Outlines of Dogmatic Theology." London, 1895.

Jones, Rev. Spencer, M.A. "England and the Holy See." London, 1892.

Kenrick, Dr F. P. "The Primacy of the Apostolic See." New York, 1848.

Kuypers, DoM. A. B. "The Book of Cerne." Cambridge, 1902.

Laniean, Rev. John, D.D. "Ecclesiagtical History of Ireland." Dublin, 1829.

Lear, REv. E. C. "The Christian Faith in Early Scotland." London, 1885.

Levwici, Rev. E., LL.D. "Antiquities of Ireland." Dublin, 1804.

Lingard, Rev. John, D.D. "The History and Antiquities of the Anglo-Saxon Church." London, 1845.

Livius, Rev. T., C.SS.R. "St Peter, Bishop of Rome." London, 1888.

MacCarthy, Rev. B., D.D. "On the Stowe Missal," vol. xxvii. Transactions of the Royal Irish Academy.

MerRy del Val, RapHael, D.D. (now Cardinal). "The Truth of Papal Claims." London, 1902.

Migne, L'A Abe J. P: “Patrologia Latina et Græca." Paris.

Moberly, Georak H., M.A. "Ven. Bedæ Historia Eeclesiastica." Oxford.

Moran, Cardinal. "Irigh Saints in Great Britain." 1903.

Moran, Rev. Patrick F., D.D. (now Cardinal). "Essays on the Origin, Doctrines, and Discipline of the Early Irish Church." Dublin, 1864.

Morris, Rev. W. B. "Life of St Patrick." London, 1878.

Morpix, J. N. "The Chair of Peter." London, 1883. 
Newman, Cardinal. Works. London.

O'Corry, Eugene, M.R.I.A. "Lectures on MS. Materials of Ancient Irish History." Dublin, 1861.

O'Hanlon, Very Rev. John Canon, M.R.I.A. " Lives of the Irish Saints."

O'LAverty, Rev. Jamrs, M.R.I.A. "A Historical Account of the Diocese of Down and Connor." Dublin, 1878.

Phillips, Rev. George. "St Columba's Monks and Rome," Ushaw Magazine. March 1899, July 1899, March 1900.

Puller, Rev. F. W. "The Primitive Saints and the See of Rome." London, 1893.

Richardson, Rev. H. "The Catholic Claims." London, 1889.

Rivingron, Rev. Luke, M.A., D.D. "The Primitive Church and the See of St Peter." London, 1894.

Salmon, John, M.R.S.A.I. "The Ancient Irish Church." Dublin, 1897.

Skene, W. F. "Celtic Scotland." Edinburgh, 1897.

Skr.se, W. F. "Joannis de Fordun Chronica." Edinburgh, 1871. Sмiтн, John, D.D. " "Life of St Columba." Edinburgh, 1798.

SuITH AND WACE. "Dictionary of Christian Biography."

Stokes, George T., D.D., M.R.I.A. "Ireland and the Celtic Church." London, 1900.

Stokes, Whithey, D.C.L., LL.D. "The Tripartite Life of St Patrick, with other Documents relating to that Saint." London, 1887.

Todd, Rev. James Henthorn, D.D. "St Patrick, Apostle of Ireland." Dublin, 1864.

Ussher, Most Rev. James, D.D. Works. Dublin, 1864.

VAUGhan, Bernard, S.J. “The Roman Claims." Manchester, 1895.

W ARREN, Rev. F. E., B.D., F.S.A. "Antiphonary of Bangor." London, 1893.

WARren, Rev. F. E. "The Liturgy and Ritual of the Celtic Church." Oxford, 1881.

Waterworth, Rev. James. "The Faith of Catholics." London. Wrighr, Rev. C. H. H., D.D. "The Writings of Patrick, the Apostle of Ireland." London.

Zimmer, Heinrich. "The Celtic Church in Britain and Ireland." London, 1902.

The Works of the Catholic Truth Society, as also Articles in The Dublin Review, Irish Ecclesiastical Record, and The Month, have also been consulted. 


\section{DATES OF PRINCIPAL EVENTS}

Celtic Apostles

\begin{tabular}{|c|c|c|c|c|c|c|c|}
\hline & & & & & Birth & Mission & Death \\
\hline St Ninian . & • & - & . & A. D. & 360 & 397 & 432 \\
\hline St Patrick . & - & - & . & , & 389 & 432 & 493 \\
\hline St Kentigern & . & . & . & $"$ & 518 & 543 & 603 \\
\hline St Columba & . & . & . & " & 521 & 563 & 59 \\
\hline St Columbanus & . & . & . & & 543 & 590 & 61 \\
\hline St Aidan . & . & . & - & , & $580 ?$ & 635 & 65 \\
\hline
\end{tabular}

A.D.

177. King Lucius sends to Rome for missionaries.

200. Mission from Pope Victor to Scotland.

314. British bishops at Arles.

347. British bishops at Sardica.

359. British bishops at Rimini.

409. Roman Occupation of Britain ceases.

422. Celestine becomes Pope.

431. St Palladius ordained by the Pope and sent to Ireland.

432. Celestine dies.

440. Leo the Great becomes Pope.

550 (?). Gildas the historian.

597. St Augustine lands in Kent.

604. St Gregory the Great dies.

605. St Augustine dies.

625. St Paulinus begins apostolate in Northumbria.

634. Paschal Epistle of Cummian written.

661. St Colman goes to Lindisfarne.

664. Whitby Conference.

673. Venerable Bede born.

679. St Adamnan becomes Abbot of Iona.

680. St Wilfrid testifies to the orthodoxy of the Celts in a Roman Council.

704. St Adamnan dies at Iona.

716. The reformed Easter adopted at Iona.

735. Death of Bede. 


\section{PART I \\ PAPAL CLAIMS}





\section{The Early Scottish Church}

\section{CHAPTER I}

INTRODUCTORY

For more than two centuries past the nonpapal character of the ancient Churches of Scotland and Ireland has been persistently dwelt upon. One writer after another has repeated the story that neither St Patrick nor St Columba owed any allegiance to the Pope, and that consequently the Christianity which they taught was not "Roman " Catholicism. This theory, apparently, dates back to the seventeenth century, when Dr Ussher, Protestant Archbishop of Armagh, declared that, although St Patrick received his mission from Pope Celestine, nevertheless the doctrine he taught, and the Church he founded, were independent of Rome. ${ }^{1}$

The circumstance that has led to the widespread adoption of Ussher's contention is, undoubtedly, the painful position in which

1 Ussher's Works, vol. iv. pp. 260 and 357. 
the so-called reformed Churches find themselves. They are engaged in a perpetual and pathetic search for a connecting link with the ancient Church of this land, in order to disprove the fact that they owe their origin to political if not to unworthy agencies. In their search for an ecclesiastical ancestor they eagerly seize upon every real or fancied deviation from the doctrine or discipline of the Catholic Church ; and if hard pressed, they bring even trivial divergencies as proof positive that the early Scots were incipient Presbyterians or Episcopalians, as the case may be. Such has been the general treatment of the ancient Christian Churches of Scotland and Ireland during the past two centuries by the majority of non-Catholic writers. Recently, however, a more impartial spirit is supposed to have taken possession of Scottish historians; but, notwithstanding this, there are invariably set down the old qualifications, that the ancient Scottish Church owed "no allegiance to Rome," and knew nothing of what is styled "Mariolatry." Thus it happens that the ancient Celts are in much the same position, in the eyes of the world, as their less liberal panegyrists left them. 
It may be well to compare the old with the newer theories.

(1) Dr Ussher wrote: "The religion professed by the ancient Christians of this land [Ireland] was, for substance, the very same with that which now by public authority is maintained therein, against the foreign doctrine brought in thither in later times by the Bishop of Rome's followers." 1

(2) This assertion is thus somewhat improved upon by Dr. Smith in the year 1798: "With the errors which at that time prevailed in the Church of Rome, they [the monks at Iona] seem not to have been in the least tainted. Columba withstood her errors." "

(3) Dr Fowler, in his introduction to Adamnan's "Vita S. Columbre," published in 1894, thus describes the religion of $\mathrm{St}$ Columba: "It was certainly neither 'Roman' nor 'Protestant,' in the ordinary sense of those terms; the modern system that comes nearest to it is that of the Churches of the Anglican Communion, as understood by the school which has arisen out of the Tractarian movement. . . We find no indication of

1 Ussher's Works, vol. iv. p. 238.

"Smith's "Life of St Columba," p. 114. 
the 'worship' now offered to the Blessed Virgin and the Saints . . . nor the least allusion to any supremacy in the See of Rome, or indeed any connection therewith." ${ }^{1}$

On reading such an astounding comparison one cannot refrain from allowing the mind to imagine a Tractarian bishop, with wife and family, transferred to the time of $\mathrm{St}$ Columba, visiting the Saint in his monastery, and informing him that he had come on pilgrimage to do penance for his sins. Supposing St Columba to have been deceived as to the validity of Anglican Orders, what would he have said to the Tractarian bishop? Firstly, he would have been told to make his confession; after which there would have been imposed upon him the obligation to fast for five years on bread and water, because it was unlawful for a bishop to live in the married state. Secondly, he would have been admitted to Holy Communion only after he had performed six months of the aforementioned penance. ${ }^{2}$ Imagine his feelings! $\mathrm{He}$ would have

1 Introduction, p. Ixxvi.

"Canons 2 and 3 of St Cunmian, vide Migne, P.L., vol. Ixxxvii. p. 983. Cummian was born beforo Columba died. The Penitential of St Columbanus and that of the Bobbio Missal enjoin similar punishments. 
thanked Dr Fowler for his kind endeavour to identify the Tractarian movement with the Columban Church.

(4) So learned and generally fair-minded a writer as Bishop Lightfoot says that St Columba's "missionary work was altogether independent of Rome. . . . Celtic Christianity grew up a strictly native growth. . . . It was not till the twelfth century ... that, along with the English Conquest, the yoke of Roman dictation was firmly riveted on the neck of the ancient Irish Church. . . This independence Columba brought with him to his new island home." 1 And again : "The Tonsure and Easter are trivial matters; the real issue lay behind all these petty disputes. . . . It was the alternative of allegiance to Rome or allegiance to Iona. . . We must not forget that the submission required by Gregory and his immediate successors was different in kind from the imperious demands of Rome in a later age." ${ }_{2}$ These gratuitous assertions of Dr Lightfoot will receive attention in the following pages.

(5) In the year 1902 a statement was

1 Lightfoot, "Leaders in the Northern Church," p. 7.

2 Ibid. p. 16. 
made on behalf of Dr Russell (the then Moderator of the Established Church of Scotland) in the pages of The Scotsman. It ran as follows:- "Even as to faith, the Columban Church before Adamnan's time was neither Roman, nor what by anticipation might be called Protestant. It accepted some doctrines, like the 'Real Presence' (apparently, at least), which most Protestants reject; but it was also free, so far as the records show, from some notable beliefs-e.g. the title of the Virgin Mary to adoration (sic), which the Roman Church has upheld; and, as already stated, there is no trace during this period of any belief in the Papacy on the part of the Church of St Columba."

The writer of the foregoing statement further maintains that "the Church of Iona is the common source whence have descended varied streams of Scottish religious and ecclesiastical life." In his view, therefore, the conflicting systems of Presbyterianism and Episcopalianisn, and, presumably, "Romanism," arose out of the Columban Church-a theory as startling as it is new.

1 The Scotsman, 5th June 1902. 
(6) Numberless quotations might here be added bearing on the same subject, but one more reference must suffice. Speaking of the early Church of Scotland and Ireland, the well-known historian, Dr W. F. Skene, says: "We find it in close connection with the Gallican Church, and regarding the Patriarch of Rome as the head of the Western Church and the source of ecclesiastical authority and mission; and ... we can discover no trace of any divergence between them in doctrine and practice" 1 - a not unfair estimate of the relations between Scotland and Rome in ancient times. But, fearful lest his words might be taken as supporting modern "papal pretensions," Dr Skene appends the following footnote :"But the Rome of the fourth and fifth centuries was not the Rome of the Middle Ages. It was the Church of St Jerome and St Augustine. There was no question then about supremacy, and the Bishop of Rome was simply regarded with deference and respect as the acknowledged head of the Christian Church within the western provinces of the Empire, of which Rome was the capital.

$$
1 \text { “Celtic Scotland," vol. ii. p. } 5 .
$$


Questions of ecclesiastical supremacy did not emerge till the Empire was broken up." 1 It is to be regretted that Dr Skene did not consult the works of St Jerome and St Augustine before he penned his explanatory note. What the Church of those two saints held concerning papal supremacy will hereafter be shown, but it is difficult to imagine how the "Patriarch of Rome" could have been regarded as "the source of ecclesiastical authority and mission" without being acknowledged as the supreme head of the Church. Dr Skene has been generally regarded as one of the greatest authorities on Celtic history, consequently very few persons have ventured to question his statements on ecclesiastical affairs. However, his method of dealing with the correspondence between St Columbanus and Pope Boniface is so remarkable that it cannot be allowed to pass without criticism.

Columbanus, a contemporary of St Columba, with a band of Celtic monks, passed over into Gaul, where they established themselves as a community. Columbanus, having discovered

1 Papal supremacy was not questioned, because at that time the Pope was universally acknowledged as Head of the Catholic Church. Professor Bury says that in the fourth century the Bishop of Rome possessed an acknowledged primacy in Christendom ("St Patrick," p. 61). 
that there existed a discrepancy between himself and the local clergy regarding the date of Easter, addressed a letter to the Pope, asking for a settlement of the question. The Epistle concludes with a petition to the Pontiff to remember the writer in his prayers before the relics of the Apostles. A request is added, wherein Columbanus begs the Pope not to forget the decision of the Fathers of the Council of Constantinople: "That Churches among the barbarian people shall be regulated by the custom of their fathers." On these words Dr Skene has thought it well thus to comment: "The position which Columbanus took up was substantially this: Your jurisdiction as Bishop of Rome does not extend beyond the limits of the Roman Empire. I am a missionary from a Church of God among the barbarians, and, though temporarily within the limits of your territorial jurisdiction, and bound to regard you with respect and deference, I claim the right to follow the custom of my own Church, handed down to us by our Fathers." 1

A more flagrant piece of misrepresentation than this it is difficult to imagine. Needless 
to say, the words put into the mouth of the saint by $\mathrm{Dr}$ Skene were never uttered by him, neither do they express the sense of what Columbanus actually said. The facts are these. The settlement of Columbanus in Gaul was to him as his native land, consequently he wished for exemption from the observance of the Gallic Easter. His Epistle to the Pope contains no word of disrespect or arrogance; on the contrary, it is couched in the most deferential terms. He begs not merely for the Pope's opinion, but for his judgment (judicium) - a strange method, surely, of asserting Celtic independence.

The Canon of Constantinople, to which reference is made, deals exclusively with the great dioceses of the East; of Rome there is, naturally, no mention. The object of the Canon was to subject churches to the sees to which they owed their origin, and to prevent interference from other bishops. In this legislation Columbanus saw a precedent for claiming independence, not of the Roman Pontiff, to whom he was actually appealing, but of the Gallic prelates. Throughout the whole Epistle there is not a single word to insinuate that 
the Celts considered themselves independent of St Peter's successor in the See of Rome.

(7) Lastly, there is the non-Catholic contention that, previous to the coming of $\mathrm{St}$ Margaret, with her southern ideas, the Scottish Church was essentially national, and but slightly corrupted with "Popery." This is, perhaps, what might be expected from a certain class of persons who treat of history superficially, and who, by reason of their inborn prejudice and ignorance, are unable to distinguish between Catholic unity and Catholic uniformity, but it is regrettable that Dr Hume Brown, in his recent work, should have committed himself to the same error. This writer, in the second volume of his "History of Scotland," informs his readers that King David I. "definitely made the Church of Rome the national Church of Scotland," 1-a statement which will be denied by every Scottish Catholic, because it implies that the Church of the twelfth century was not identical with that of the centuries preceding ita statement having no warrant in fact.

${ }^{1}$ i. p. 94. It is really difficult to understand what Dr Hume Brown means by the "Church of Rome" in the early part of his work. 


\section{CHAPTER II}

\section{NEED OF PAPAL SUPREMACY}

As the question before us in these pages is so pre-eminently concerned with the papal position, and as so vast an amount of ignorance and misconception exists on the subject in the non-Catholic mind, it is of little use to enter upon the facts of Celtic history concerning it without previously stating, in detail, what the Catholic teaching and position regarding papal supremacy really are.

From the witness of the New Testament we learn that Christ intended His Church to spread over the whole world, so that every tongue, nation, and tribe should belong to it. It seems natural, therefore, that so vast a body, made up of such a mixture of races, should have a head and a centre of unity, in order to protect it from splitting into discordant elements through its very unwieldiness, and, still more, through human passion and frailty. The Catholic Church 
teaches that such a head was provided by Christ, in the person of St Peter and his successors; and such a centre of unity is Rome, the See of that Apostle. As a consequence of the divine institution of this ecclesiastical headship, all true Christians must be in communion with the See of Rome, where Peter rules in the person of his legitimate successors.

The result of this system is manifest to everyone-namely, the perfect unanimity of Catholics in doctrine all over the world.

This arrangement is not only part of the divine plan of the Church, but it is in accordance with right reason. For how can any body of men act without a head? The Catholic Church is a visible society, which has to rule its members and make laws for their guidance. Now, we know from common experience that societies of men cannot be kept together except by their respective heads, be they Kings, Grand-Masters, or Presidents. No Government can be carried on without a chief to whom all owe subjection. Therefore the Church must have its visible head, whom all must obey. 
But the non-Catholic replies that the Church has a head in the person of Christ, and, therefore, there is no need of vicarship. True, Christ is really the Head of the Church; but that does not militate against the "headship of St Peter, for is not God the Ruler of every kingdom, government, and society, even of that which concerns men most intimately--the Christian family? At the same time, God's authority is vested in men who are the visible rulers. "The powers that be," says St Paul, "are ordained of God." 1

The need of such a visible head as is here referred to is painfully manifest among Protestant bodies - witness the 200 or more conflicting sects claiming to be the followers of Christ at the present day. It is a curious phenomenon that the visible Church is the only body to which a ruling head is persistently denied. 


\section{CHAPTER III}

SCRIPTURAL TESTIMONY TO ST PETER'S SUPREMACY

But is there positive proof from Holy Scripture that Christ did bestow this supremacy on St Peter over the other Apostles? An unprejudiced reader will find an abundance of evidence that $\mathrm{He}$ did. In the first place, there is the fact that our Lord Himself changed the name of Simon into that of Peter (Kephas) which signifies a rock, as prophetic of the office the Apostle was to bear. ${ }^{1}$ Later on, St Matthew ${ }^{2}$ describes the circumstances of the bestowing of that office. Our Lord stands in the midst of His Apostles, and He questions them as to the opinions men entertain concerning Him. They reply that some asserted that $\mathrm{He}$ was John the Baptist; others that $\mathrm{He}$ was Elias, Jeremias, or one of the prophets. Then our Saviour asks: "But whom do you say that I am?" Peter, the leader

$$
\begin{aligned}
& { }^{1} \text { John i. } 42 . \\
& { }^{2} \text { Matt. xvi. 13-19. }
\end{aligned}
$$


and spokesman of the rest, gives the answer : "Thou art Christ, the Son of the living God." This remarkable confession was followed by our Lord's public assertion that this had been revealed to St Peter by God, and by the promise that the supreme headship of the Church should belong to him: "And I say to thee, That thou art Peter, and upon this rock I will build my Church; and the gates of hell shall not prevail against it." By these words Christ not only refers to the new name $\mathrm{He}$ had previously conferred on Simon, but He also makes known the reason for that change. Let it be remembered that our Lord was speaking in the Aramaic tongue, consequently the word "Peter" must have been the same in both portions of the text, for there was no change of gender, as there is in the Greek or Latin translations. Thus in the original the text ran: "Thou art rock (Kephas), and upon this rock (Kephas) I will build my Church."

Regarding this particular passage Robert Wilberforce says: "In Syriac the term in each member of the sentence is identical. Had St Augustine, for instance, known that 
our Lord's words were: 'Thou art Cepho, and upon this Cepho I will build my Church,' he would not have employed the argument he does in his Retractions." 1.

Nowadays all competent non-Catholic commentators have abandoned the contention that the word rock applies to any person other than St Peter. No other construction can be placed on our Lord's words without calling into question good grammar and common-sense.

The fact that St Peter is the foundation of the Church does not exclude the fact that Christ Himself is in very deed the Chief Corner-stone. Christ as the Rock in the primary sense could make Peter rock also, even as $\mathrm{He}$ has made others to share in $\mathrm{His}$ office of Shepherd, Priest, and King. It is of this primary sense that St Paul speaks to the Corinthians when he says: "Other foundations can no man lay than that is laid, which is Jesus Christ." 2

Furthermore, let it be borne in mind that an affirmative proposition is not exclusive. That Christ is the sole Foundation, that

${ }^{1}$ Spencer Jones, "England and the Holy See," p. 134.

${ }^{2} 1$ Cor. iii. 11. 
the prophets and Apostles are foundations, 1 that Peter is the rock, and that Peter's faith is the rock, are affirmative statements that do not exclude each other. They are all true, though not in the same sense.

"And I will give to thee the keys of the kingdom of heaven. And whatsoever thou shalt bind upon earth it shall be bound also in heaven; and whatsoever thou shalt loose on earth it shall be loosed also in heaven." 2 These words complete the promise to Peter.

On a subsequent occasion all the Apostles received a share in the latter portion of the promise-namely, the power "to bind and to loose"-but in the text just quoted there is no room for doubt as to the person who received it in a special manner. But let it be noted that Peter alone is made the rock of the Church, Peter alone is constituted the heavenly key-bearer. The phrase "I give to thee the keys" implies that the object is put entirely at the disposal of the recipient. To hand over the keys of a house is not merely a conventional sign of yielding possession, for he who has
${ }^{1}$ Eph. ii. 20.
${ }^{2}$ Matt. xvi. 19.
${ }^{3}$ Matt. xviii. 18. 
the key is the master." Commenting on this passage, Döllinger says: "The power of the keys differs from the power of binding and loosing, and extends over the whole Church, and passes to St Peter's successors." "This eminent historian, however, found it necessary to water down his words after he had quarrelled with the Pope. $^{2}$

Attention may here be called to a disposition on the part of High Churchmen to admit for the Pope a primacy of honour, but not of jurisdiction; in other words, to recognise him as "primus inter pares." They allege that this was the attitude of the Primitive Church and of the Celtic Churches also. This is a gratuitous assertion; for, it may be asked, is there any proportion between a mere primacy of honour and the several definite expressions of the New Testament? Would a primacy of honour suffice to maintain unity? Furthermore, is it in harmony with Christ's words and actions to confer honour merely for honour's sake?

1 The delivery of keys is always considered to imply the bestowal of authority. Note the custom of handing over the keys of the city of London and of Edinburgh at the entrance of the Sovereign. Cf. Isa. xxii. $21,22$.

2 Spencer Jones, "England and the Holy See," p. 140. 
Without appearing to beg the question, surely it is both safer, and in accordance with right reason, to rely on the literal and plain words of Holy Scripture, and their interpretation as set forth by the ancient Fathers, and embodied in the Catholic Liturgy.?

Shortly before Christ's Ascension the full promise to St Peter was fulfilled. "Jesus said to Simon Peter, Simon, son of John, lovest thou me more than these? He saith to Him, Yea, Lord, thou knowest that I love thee. He saith to him, Feed my lambs." 2 The question is repeated, and again the commission: "Feed my lambs." After a third interrogation Peter is commanded "Feed my sheep." By these words our Lord committed to St Peter His whole flock. The distinction of sheep and lambs, for both of whom St Peter is to do the work of shepherd, emphasises the fulness of the extent of his jurisdiction. The lambs are the weaker and more tender portion of the flock-namely, the faithful; the sheep are the rulers themselves, for they are to their congregations

${ }^{1}$ On this important point the reader is recommended to consult "Bishop Gore and the Catholic Claims," by Dom J. Chapman, O.S.B., chap. v.

'John xxi. 15-17. 
what sheep are to their lambs-they beget them spiritually to Christ. To no other Apostle did our Saviour say what He said to St Peter, hence St Leo's words: "Though there be among the people of God many priests and many shepherds, yet Peter ruleth all by immediate commission, whom Christ also rules by sovereign power." 1

It has now been shown that our Lord on these special occasions speaks of His Church under a threefold figure-an edifice, a kingdom, and a fold-and in each instance it is in immediate connection with the bestowing of a prerogative on Peter, and on Peter only. As an edifice, the Church rests on its foundation, and that foundation is declared to be Peter; as a kingdom, it has its visible ruler, and that ruler is Peter, who holds the keys, and binds and looses; as the one fold, the flock thereof is to be fed by the one shepherd, Peter. If these metaphors, chosen by Christ Himself, mean anything-and who will presume to question this ?-then they must be taken as significant of a supremacy, not of mere honour, but of real jurisdiction. ${ }^{2}$

'Spencer Jones, "England and the Holy See," p. 146.

"Cardinal Merry del $\nabla$ al, "The Truth of the Papal Claims," p. 12. 


\section{CHAPTER IV}

SUPREMACY OF ST PETER IN THE APOSTOLIC AGE

ThE question is often asked: "Was this supreme headship of St Peter acknowledged during the time of the Apostles?" Without assuming that the New Testament is an exhaustive manual of theology, or that the teaching of the living Church is insufficient, an appeal may be made to the Acts of the Apostles, where it will be found that St Peter is pre-eminent, and the leader of his brethren. The narration of the first half of the Acts practically resolves itself into what may be called the "Acts of St Peter," since he is the prominent figure throughout. Peter's name stands first in the list of the Apostles, just as it does in the Gospel narrative, although he was neither first in age nor in priority of election. ${ }^{1} \mathrm{He}$ is the first among the Apostles to perform a miracle. ${ }^{2}$

${ }^{1}$ Matt. x. 2; Mark iii. 16; Luke vi. 14; Acts i. 14 . For an explanation of the order of names in Gal. ii 9 see Dom Chapman's "Catholic Claims," p. 46; also The Month, August 1905, p. 219.

${ }^{2}$ Acts iii. 
It was he who stood up to address the Jews in Jerusalem while the Apostles stood around him, and by his discourse he made 3000 converts. ${ }^{1}$

When a successor is to be elected in place of Judas, Peter alone speaks, and the Apostles acquiesce in his instructions. ${ }^{2}$ In the council held in Jerusalem, Peter's address is the first recorded. Before he spoke "there was much disputing," but afterwards "all the multitude held their peace." St James and the other Apostles concurred, and the sentiments expressed by Peter prevailed.' There is, moreover, no proof forthcoming that St James presided at this council, or that he decided any question. The Greek word, krino," meaning "I judge," or "I am of the opinion," does not imply an authoritative decision on the part of St James. St John Chrysostom, himself an Oriental, maintains that it was St Peter who allowed the discussion and gave the decision. ${ }^{5}$

Notice, too, the anxiety of the Church of Jerusalem as soon as Peter is apprehended and imprisoned. Special efforts are at once

1 Acts iii.

$$
{ }^{2} \text { Acts i. }
$$

${ }^{3}$ Acts xv.

- Acts Xv. 19.

-Vide Dom Chapman, "St Chrysostom on St Peter," Dublin Review, January, 1903. 
made, and prayers go up unceasingly from the whole Church for his deliverance-facts which are not recorded to have taken place when St James was seized. ${ }^{1}$ To add yet another instance, St Peter's visitation of the Churches was not confined to those which he himself had founded, but it extended to all without exception, as the following words clearly indicate :- "And it came to pass that Peter, as he passed through, visiting all." 2 Commenting on this passage, St Chrysostom remarks : "Peter, like a general, went round surveying the ranks, seeing what portion was well massed together, what in order, what needed his presence. Behold him making his rounds in every direction." 3 On all these occasions St Peter is so prominent that his supremacy of jurisdiction is not only apparent, but it is forced on the judgment of an impartial mind.

1 Acts xii.

2 Acts ix. 32.

s Spencer Jones, "England and the Holy See," p. 152. 


\section{CHAPTER V}

OBJECTIONS TO ST PETER'S SUPREMACY

The pre-eminence held by St Peter in the Apostolic age is so manifest that no passage of Holy Scripture has been overlooked by non-Catholics that might militate against this position. These objections may be resolved into the three following:-

(1) Our Lord rebuked Peter. ${ }^{1}$ But how can this invalidate Peter's prerogatives? Christ was Peter's Superior, and no one questions the right of a superior to rebuke his servant, without in any way derogating from that servant's privileges.

(2) St Paul withstood Peter to the face. ${ }^{2}$ This, again, is no argument against the Primacy, unless it be first proved that it is always unlawful for an inferior to correct a superior. At any rate, this is not the teaching of Christianity. ${ }^{3}$ St Thomas Aquinas declares that not only is it allowed (on a fitting occasion) for a subject to correct his

${ }^{1}$ Matt. xvi. 23.

${ }^{2}$ Gal. ii. 11-14.

Matt. xviii. 15. 
prelate, but he may be even bound to do so. ${ }^{1}$

There are many instances on the part of holy persons who have acted on this teaching. St Bernard, St Thomas of Canterbury, and St Catherine of Siena may be quoted as having reproved Popes, but their loyalty and obedience to papal authority remained unquestioned. It would excite no surprise at the present day to learn that one of the cardinals had called the attention of the Pope to the probability of scandal arising among the faithful from some course of action which he had adopted without due consideration. Such a counsellor would receive praise rather than blame. But what St Paul did is no more than that cardinal would do. The facts are these: St Paul reproved St Peter for withdrawing from the table of the Gentile converts, lest he should give offence to converts from among the Jews. It involved no question of faith, but only of expediency. Indeed, the very fact that St Paul deemed his action worthy of record affords confirmatory proof of St Peter's supremacy. Had it concerned an equal or an inferior it is prob${ }^{1}$ Sum. Theo. 2, 2, q. 33. aa. 3 and 4. 
able that no notice would have been taken of the incident. Furthermore, it is stated by St Paul that Peter's example would compel the Gentiles to live as Jews-a most forcible expression, showing the immense influence that St Peter possessed, because the contrary example of St Paul had no power to compel the faithful to imitate him.

St Paul's habitual deference towards St Peter may be gathered from the same Epistle. ${ }^{1}$ He says: "I went to Jerusalem to see Peter, and I tarried with him fifteen days." The word "istoresai," which is translated "to see," does not occur elsewhere in Holy Scripture; in profane authors it is used of visits to impressive objects, such as to an oracle. ${ }^{2} \mathrm{St}$ John Chrysostom says that St Paul "goes to him" [i.e. Peter] as to a superior and senior." 3 "It was meet," writes a contemporary of St Ambrose, "that he should desire to see Peter, because he was first among the Apostles, and to him the Lord had delegated the care of the churches." 4

(3) Finally, it is objected that the Apostles

${ }^{1}$ Gal. i. 18.

${ }^{2}$ Hunter's "Outlines of Dogmatic Theology," vol. i. p. 423.

${ }^{3}$ In cap. i. ad Gal. Migne, P.G., lxi. col. 631.

"Murphy, "Chair of Peter," p. 20. 
sent Peter and John to confirm the converts in Samaria. ${ }^{1}$ Here it should be remarked too that Peter is placed first by St Luke; and in the record of what happened St John acts a second part-it is Peter alone who teaches, commands, judges, condemns. ${ }^{2}$ It is true that "to send" implies the superiority of the sender; but is the term used in no other sense? There are examples in Holy Scripture where the word is employed to denote the result of a proposal having been made and accepted, and this may well be regarded as having happened in the case of Peter and John and the other Apostles. ${ }^{3}$ In the instance before us it would be unwarrantable to infer that Peter and John were considered the inferiors of the rest of the Apostles. The obvious meaning, therefore, of the passage is that the Apostles urged the expediency of the visit of Peter and John. ${ }^{4}$

1 Acts viii. 14.

2 Acts viii. 19-23.

${ }^{3}$ Cf. Josue $x \times$ ii. 13, 14, and Acts xv. 2.

"Kenrick, "The Primacy," p. 86 ; Allies, "St Peter," p. ix. 


\section{CHAPTER VI}

PATRISTIC TESTIMONY TO ST PETER'S SUPREMACY

To the testimony of Scripture regarding the Primacy may be added that of the early Fathers. These writers, belonging to the first five centuries-for beyond that date we need not go - are men whose orthodoxy is admitted by the majority of Christians. They are also regarded by many as pre-eminently the guardians of "the Faith once delivered to the Saints."

A selection of quotations from their works will here be given; but the reader who desires more complete and copious extracts is directed to "Cathedra Petri," by Charles F. B. Allnatt, where he will find collected together a quantity of quotations forming an overwhelming consensus in favour of the Catholic doctrine. The following translations, representative of East and West, are almost all taken from $\mathrm{Mr}$ Allnatt's accurate and invaluable work:- 


\section{St Peter the Rock}

(1) Origen, A.D. 216: "See what is said by the Lord to that great foundation of the Church and most solid Rock upon which Christ founded the Church : ' $O$ thou of little faith, why didst thou doubt?" "1

(2) St Cyprian, A.D. 248: "There is one Church founded by Christ our Lord upon Peter, for the origin and purpose of unity." 2

(3) St Hilary of Poitiers, A.B. 356: "Oh, in thy designation by a new name, happy foundation of the Church, and the rock worthy of the building of that which was to scatter the infernal laws, and the gates of hell, and all the bars of death." 3 And again : "Blessed Simon underlying the building of the Church, and receiving the keys of the kingdom of heaven." " The witness of St Hilary is particularly interesting, as he was a friend of St Martin of Tours, whose indirect influence on Celtic monasticism was considerable.

(4) St Gregory Nazianzen, A.D. 370 : "Seest thou that of the disciples of Christ, all of whom were exalted and deserving of the

1.In Exod. Hom. v. n. 4, tom. ii.

2 Epist. Ixx. ad Januar.

Comment. in Matt. xvi. 7, tom. i.

- De Trinit. i. 4, c. 20, tom. ii. 
choice, one is called a rock, and is entrusted with the foundations of the Church." 1

(5) St Ambrose, A.D. 385: "Therefore where Peter is there is the Church." 2

(6) St Augustine, A.D. 400: "Peter .. the rock upon which the Church should be built." 3

(7) In the General Council of Ephesus, A.D. 431, the Legate Philip called St Peter "the pillar of the. Faith, the foundation of the Catholic Church." 4 And in the sentence against Dioscor'us, approved by all the Bishops of the General Council of Chalcedon, A.D. 451, Peter is styled "the rock and foundation of the Catholic Church, and the foundation of the Orthodox Faith." 5

\section{St Peter the Key-Bearer}

(1) Origen observes that there is "much difference between what is spoken to Peter and what to the others. For it is no small distinction that Peter should receive the keys ... for they (the other Apostles) do not transcend in power as Peter, so as to bind and loose in all the heavens." 6

\footnotetext{
${ }^{1}$ Orat. xxxii. n. 18, tom. i.

$\because$ In P's. xl. n. 30, tom i.

${ }^{3}$ In Ps. Ixix. n. 4, tom. iv.

* Conncil Eph. Act. iii.

${ }^{5}$ Council Chal. iii.

"In Matt. tom. xiii. n. 31.
} 
(2) St Cyprian says: "The Church, which is one, and was by the voice of the Lord founded upon one, who also received the keys thereof." 1

(3) St Cyril of Jerusalem in his Catechism calls Peter "the Prince of the Apostles, and the Key-Bearer of the kingdom of heaven." 2

\section{St Peter the Chief Pastor}

(1) Origen: "When the chief authority as regards feeding the sheep was delivered to Peter, and upon him as on the earth the Church was founded." 3

(2) St Ambrose: "Set over the Church . . . the Pastor of the Lord's flock." ${ }_{4}$

(3) St John Chrysostom: "The third time He gives him the same injunction, showing at what a price He sets the presidency over His own sheep." And again: "He puts into his hands the presidency over the brethren." 5

(4) St Augustine: "I am held in the communion of the Catholic Church by ... the

1 Epist. Ixxiii, ad Jubian n. 11.

${ }^{2}$ Catech. xvii. n. 27.

${ }^{3}$ Lib. v. in Epist. ad Rom. n. 10, tom. iv.

In Pr. xliii. n. 40.

${ }^{5}$ In Joan. Hon. Ixxxviii. n. 1. tom. viii. 
succession of priests from the very Chair of the Apostle Peter, to whom the Lord, after His resurrection, committed His sheep to be fed, even to the present Episcopate." 1

(5) St Jerome: "One is chosen out of the twelve, in order that, a head being appointed, the occasion of schism might be removed." 2

${ }^{1}$ Tom. viii. cont. Epist. Manich. Fund. n. 5.

${ }^{2}$ Adv. Jovin. lib. i. n. 26, tom. ii. 


\section{CHAPTER VII}

ST PETER FIRST BISHOP OF ROME

Adhering to an uninterrupted tradition, the Catholic Church unhesitatingly affirms that St Peter spent some years in Rome, was its first bishop, and finally suffered martyrdom there.. Under the stress of controversy these facts have been denied by certain Protestants, and the denial is still repeated by a class of controversialists who ignore research and the facts of history. The best refutation of the unscholarly assertion that St Peter was never in Rome is the long list of nonCatholic writers who have admitted the fact as indisputable. ${ }^{1}$ The testimony of Holy Scripture also is not wanting, for the generally received interpretation of St Peter's own words: "The Church that is in Babylon saluteth you," 2 asserts that the Babylon here

1 This list would include such names as Whiston, Cave, Grotius, Pearson, Branhall, Renan, Lightfoot, Ellicott, Farrar, Westcott, Gore, Harnack, etc.

"1 Peter v. 13. Dr Barry, in his work "Papal Monarchy," asserts that this name was given to Rome in the ancient Sibylline books of Jewish origin, and thus long before St Peter's time. (vide p. 18). 
mentioned refers, in fact, to Rome, and that it was from that city that the Apostle wrote his Epistle. St Peter, therefore, is speaking metaphorically, and he uses the term Babylon to express the corruption of morals prevalent at that time in the capital of the Empire. A desire to conceal the place of his residence from the onslaught of persecutors may also have influenced him to use the word in its metaphorical signification.

It is worthy of note that St Paul had not visited Rome when he wrote his Epistle, and directed it to the Church constituted in that city. ${ }^{1}$ By whom, then, had the Roman Church been founded, the faith of which "was spoken of in the whole world"? Undoubedly by St Peter ; for Christian antiquity points to him and St Paul alone as having been its first founders.

St Peter's Roman Episcopate is a fact which is established by historical evidence reaching back to primitive times. It was never questioned by any heretic or schismatic until late in the Middle Ages. The Eastern Christians who broke away from Rome in the early centuries never thought of deny-

${ }^{1}$ Romans i. 10-13; xv. 22, 23. 
ing that St Peter was Bishop of Rome, although to do so would have been one of the strongest justifications of their schism. Rome itself is teeming with memories of the Apostle Peter; among them are the dungeons in which he was imprisoned, his chains, the place of his martyrdom, and, above all, his tomb. Furthermore, the feast of St Peter's Chair, one of the most ancient in the calendar, dating back to at least the year 336, expressly commemorates the Roman Episcopate of the Apostle.

An objection has sometimes been made that, in the lists of the Bishops of Rome that have come down to us from writers such as Irenæus and Eusebius, Popes Linus, Cletus, and Clement are reckoned as the first, second, and third bishops respectively. But Irenæus and Eusebius are giving the succession from the Apostles, Linus being the first after Peter; hence St Peter is not really excluded from the list. ${ }^{1}$

One quotation from Tertullian (born A.D. 150) may suffice to indicate what the

"Vide Allnatt, "Cathedra Petri," p. 118. The reader who desires to study this question more fully is directed to Father Livius' "St Peter, Bishop of Rome"; Dr Kenrick's "Primacy"; and Mgr. Barnes' "St Peter in Rome." 
primitive tradition really was regarding $\mathrm{St}$ Peter's residence and martyrdom in Rome: "Run through the Apostolic Churches, in which the very Chairs of the Apostles to the present day preside over their own places; in which their own original letters are read, echoing the voice, and making present the face of each. Is Achaia near to thee? thou hast Corinth. If thou art near to Italy, thou hast Rome, whence we also have an authority at hand. That Church, how happy! into which the Apostles poured out all their doctrine with their blood; where Peter had a like Passion with the Lord; where Paul is crowned with an end like the Baptist's." 


\section{CHAPTER VIII}

SUPREMACY OF ST PETER'S SUCCESSORS

THE words of Christ were meant for all time; what $\mathrm{He}$ said to $\mathrm{His}$ disciples $\mathrm{He}$ said to all disciples through all ages; the commands He gave to $\mathrm{His}$ Apostles $\mathrm{He}$ gave to their successors for ever. For example, when $\mathrm{He}$ said: "Go, therefore, teach ye all nations, baptising them in the name of the Father, and of the Son, and of the Holy Ghost," 1 $\mathrm{He}$ commanded their successors for ever to teach and baptise. So, in like manner, when He gave supreme authority to Peter, it was not merely for that Apostle's lifetime, for that would have been of little use to the Church, but He gave it to him and his successor's to the end of the world. ${ }^{2}$ It is, therefore, part of the Catholic Faith that the official prerogatives of St Peter have been handed on to his successor's in the See of Rome, and that they will continue with

Matt. xxviii. 19.

2 Cf. Matt. xxviii. 20. 
every lawful Pope through all ages yet to come.

St Peter, it is true, possessed other gifts besides those inherent in his office as supreme Pastor; such were inspiration and the power of working miracles; these were personal, and not official; they were given for the nourishment of the infant Church, and ceased with the mortal career of the Apostle. But it is otherwise with the powers belonging to the Apostolic office. Of these Cardinal Merry del Val says: "They could not cease with Peter's life, because in him the Apostolic Office was not merely personal, but was established by Christ as an essential, and necessarily enduring, element in the very constitution of the Church. The body of the Catholic Bishops-that is to say, the Catholic Episcopate-succeeds to the College of the Apostles, and is therefore supreme and infallible, but the Catholic Episcopate includes the Bishop who is pre-eminently the Bishop of Christ's Fold . . . without him there can be no Catholic Episcopate, and no succession from the Apostles, according to the mind of Christ . . nor are the Bishops mere delegates of the Roman Pontiff. This 
is expressly repudiated and condemned by the Church."1

The Rock-foundation, then, which is to sustain Christ's edifice is essential to the whole construction, for that which does not rest on the foundation is not part of the house; the Ruler who has the keys is indispensable for the well-being of the kingdom ; the Shepherd who feeds and leads the whole flock by divine commission - that is, by Christ the Good Shepherd-cannot be absent from the fold if it really is Christ's own. Hence the supreme headship of Peter endures, and must endure, in the Catholic Church till the end of time.

${ }^{1}$ Merry del Val, "The Truth of Papal Claims," p. 15. The reader who desires a full explanation of St Gregory's repudiation of the title of "Universal Bishop" is referred to Fr. Hunter's "Out. lines of Dogmatic Theology," vol. i. p. 439. 


\section{CHAPTER IX}

TESTIMONY OF HISTORY AND OF THE FATHERS TO PAPAL SUPREMACY

Evidence exists in the pages of history to prove that the Popes have ever claimed and exercised supreme jurisdiction over the whole Church-in the West till the so-called Reformation; in the East till the Greek schism in the ninth century. From first to last in the history of Christianity there is one conspicuous person and one conspicuous See-that person is the Pope, and that See is Rome. Looking back into the past, we find a line of Popes stretching back to St Peter. Those who question the continuity of this chain must first point out the "missing links." It is to no purpose to bring forward the case of anti-Popes, as there has never been more than one legitimate Pope recognised at one time-the controversy was about persons, not about dogma. Then, again, no one can tell when the doctrine of papal supremacy was first promulgated. Is it 
not singular that for almost 2000 years men and women of every clime and every country, people of different temperaments and of different Governments, have quietly acquiesced in the dogma of the Pope's supremacy?

But a word of warning is necessary. In looking back to the first centuries of the life of the Church, it would be unreasonable to expect to find a fully developed papal administration, such as exists to-day; that was a time when Popes were hunted down by persecuting tyrants, and so compelled to live "in dens and in caves of the earth,"1 as were St Urban I., St Marcellus, etc.

Christ was content to plant, so to speak, the seed of papal supremacy; He left to time the task of bringing to its full growth what the world calls Ultramontanism-_ "for the leaves of the tree are for the healing of the nations." 2 To those who reflect that the Church itself was but a slow development, as from "a grain of mustard seed," there can be no real difficulty in the scanty references to the exercise of papal prerogatives in the primitive ages. The papal power

1 Hebrews xi. 38.

${ }^{2}$ Apoc. xxii. 2. 
inherent in the Church developed with the life of the Church. It can readily be admitted that even the early Bishops of Rome themselves may have had but little idea of all that time would show to have been involved in our Lord's promise and commission to St Peter. The latter, it is true, could only transmit to his successors what he himself possessed; but can it be maintained that his privileges were non-existent, and therefore non-transmissible, simply because circumstances delayed their fuller assertion and exercise? On the contrary, it would seem to have been essential to prevent their premature development while the Church was in its state of infancy.

"While the Apostles were on earth," says Cardinal Newman, "there was need neither of Bishop nor Pope; their power was dormant, or exercised by Apostles. In the course of time first the power of the Bishop awoke, and then the power of the Pope. . . . For St Ignatius to speak of Popes, when it was a matter of Bishops, would have been like sending an army to arrest a housebreaker. .. . It is a less difficulty that the Papal Supremacy was not formally acknow- 
ledged in the second century than that there was no formal acknowledgment of the doctrine of the Holy Trinity till the fourth. No doctrine is defined until it is violated." 1

Then, again, it must be borne in mind that the history of the Early Church, such as we have it, is very imperfect. We have but a scrap here and a fragment there, but, notwithstanding this deficiency, ample evidence exists to indicate that papal supremacy was always maintained and acknowledged.

True it is that instances may be quoted of bishops here and there coming into conflict with the central See of Christendom; but facts of this nature do not demonstrate disbelief in Christ's institution of the Primacy, any more than recalcitrant priests prove the absence of belief in the divine origin of Episcopacy.

1 Newman, “ Development of Doctrine," pp. 165-168. 


\section{CHAPTER $\mathrm{X}$}

\section{OBJECTIONS TO PAPAL SUPREMACY}

The arguments against the Pope's supremacy, so laboriously built up by writers like Gore, Puller, and Salmon, originate either from a travesty of the Catholic teaching, or concern isolated examples of refractory prelates, chafing under the exercise of papal authority. To maintain that the opposition of Polycrates, $\mathrm{St}$ Cyprian, and Firmillian regarding disciplinary enactments is equivalent to denial of papal supremacy is futile in face of the overwhelming evidence to the contrary.

At one time St Cyprian considered that the Pope had encroached on his episcopal rights in the matter of the rebaptising of heretics. Mr Puller, in consequence, would have us believe that Cyprian was anti-papal, in spite of the Saint's own protestation that "there is one God, and Christ is one, and there is one Church, and one Chair [namely, St Peter's], founded upon the rock by the word of the 
Lord." 1 As a matter of fact, St Cyprian is one of the most strenuous upholders of papal supremacy, although in one instance he resisted the Pope. ${ }^{2}$

Dr Gore, in his "Roman Catholic Claims," endeavours to convince his readers that up to the fifth century a certain deference was paid to the successors of St Peter, but that during the pontificate of St Leo the Great (440-461) claims of an utterly different character began to be made by the Roman Pontiffs. Had this been the case, is it likely that those claims would have been allowed to pass without energetic protest? There have always been holy men to cry out against innovations in doctrine. Had matters been as Dr Gore and $\mathrm{Mr}$ Puller would have us believe, there would have been protestation written large across the pages of fifthcentury history. But instead of this we find Eastern emperors and Eastern bishops acquiescing; and when the latter seek to obtain arrangements opposed to the Pope,

1 Epist. xxxix. 5.

2 The passage from St Cyprian's treatise "De unitate" is now considered genuine by several able scholars, and not an interpolation. The opinion recently set forth by Dom Chapman, O.S.B., has been endorsed by Prof. Harnack, vido The Tablet, 22nd May 1903. 
they approach him, not as denouncers, but as suppliants. ${ }^{1}$

Furthermore, non-Catholics constantly insist that the supremacy accorded to the Roman See was entirely due to its connection with the imperial city. How comes it, then, that no Pope ever appeals to that fact? On the contrary, the Primacy of Rome was always regarded by the Christian world as originating from the fact that it was the Apostolic See. If connection with the imperial city conferred the supremacy, why did not Constantinople in her day put in her claim to rank first, before Rome? Yet it is a matter of history that she never attempted to assume any but a second place. $^{2}$

That papal supremacy did not originate because of the unique position of Rome is evident from the emphatic decree of a Roman Council held A.D. 494. The words of the Council are these: "The Holy Roman Catholic and Apostolic Church has been preferred to the rest [of the churches] by no decree of a Council, but has obtained the

1 Fr. Richardson, "Catholic Claims," in reply to Dr Gore.

2 Fr. Bernard Vaughan, S.J., "Roman Claims," p. 108. 
Primacy by the evangelic voice of our Lord and Saviour Himself, saying: 'Thou art Peter, and upon this Rock,' etc. First, therefore, is the Roman Church the See of Peter, not having spot, or wrinkle, or any such thing." 1

Much has been made by our opponents of the twenty-eighth Canon of Chalcedon. These are its words: "The Fathers gave Rome the Primacy." This phrase was not passed by the 630 bishops who sat in the Council. According to Milman, this Canon received the subscription of but 150 prelates, the most of whom belonged to the diocese of Constantinople. As the Pope refused to confirm it, the famous twenty-eighth Canon never received recognition or acceptance in the Western Church, and it, therefore, remains useless. To say that the Fathers of Nicæa gave the Primacy to Rome is historically false. ${ }^{2}$ If the reader would know the true

2 Translation by Dom Breen. See Guardian, 23rd April 1902; also "Cathedra Petri," p. 80.

${ }^{2}$ In explanation of the word Fathers, used in this abortive Canon, Mr A. St Leger Westall suggests that the knot of prelates were making reference to the Apostles St Peter and St Paul, the praises of whom had been proclaimed a short time before by St Leo hinself, under this very title of "The Fathers." Sec art. "Primacy," Dublin Review, January 1903.

Since the above was written Dom Chapman, O.S.B., has published his book entitled "Bishop Gore and the Catholic Claims." 
feeling of the Council of Chalcedon on the subject of the supremacy, he will find it expressed in the unanimous cry of the prelates: "Peter has spoken by Leo"; as also when they addressed the Roman Pontiff as "the very one to whom the care of the Vine has been committed by the Saviour"-words which, if they mean anything, express unhesitating belief in the divine institution of papal supremacy. ${ }^{1}$

The so-called "Forged Decretals" are not unfrequently quoted as having originated "the exorbitant claims of the Papacy." Suffice it to say that these Isidorian Decretals were composed about the middle of the ninth century, not in Rome, but in France. Papal supremacy had been fully maintained and exercised before the Decretals were even thought of. ${ }^{2}$

Advanced Anglicans bring forward the

This is probably one of the most erudite and convincing works hitherto written on behalf of the Papacy. The learned author says that the Bishops in the abortive Canon did not use the expression "the Fathers gave," for the Greek cannot possibly mean this. The Greek verb signifies "I return a loan," or "I render a due." "The Fathers contiuued to 'render' the same honour which Peter had given to the capital," p. 86.

${ }^{1}$ Sess. ii. ; Epist. Synod. Leoni.

${ }^{2}$ This subject is admirably dealt with by Rev. R. F. Clarke, S.J., in a Catholic Truth Society pamphlet entitled "The False Decretals." 
additional objections of-(1) the "schism" at Antioch ; (2) the Accacian Troubles ; (3) the affair of Apiarius-all of which have been so thoroughly and satisfactorily discussed by $\mathrm{Dr}$ Rivington, Dom Chapman, and other able Catholic writers, that it seems incredible that any Anglican, or other Protestant, can bring himself to believe that questions of this nature justify severance from Rome, the centre of unity. ${ }^{1}$

${ }^{1}$ Mr Puller's arguments have been ably refuted by the late Dr Rivington in his work "The Primitive Church and the See of Peter" (Longmans, 1894). Other Catholic works on the papal question recommended are: "The Roman Primacy," by Dr Rivington; "The Primacy," by Bishop Kenrick ; "The Chair of Peter," by J. N. Murphy ; "St Peter," by T. W. Allies; "St Peter, Bishop of Rome," by Father Livius, C. SS. R. ; "Cathedra Petri," by C. F. B. Allnatt; "The Supremacy," by Dr Hettinger; "The Roman Claims," by Father Bernard Vaughan, S.J. ; "The Truth of Papal Claims," by Cardinal Merry del Val ; "Bishop Gore and the Catholic Claims," by Dom J. Chapman, O.S.B., and issued by Longmans at the prices of Is. and $6 \mathrm{~d}$. 


\section{CHAPTER XI}

EXERCISE OF PAPAL SUPREMACY IN EARLY TIMES

TuRning from the special pleading of certain non-Catholic writers, it will be of interest to know how the Popes exercised their prerogative in early ages.

(1) The first example belongs to the lifetime of St John the Evangelist. In the scanty records of the first age of the Church we read that dissensions broke out in Corinth. Matters went so far that a rebellious faction presumed to depose the clergy. The Corinthians caused the whole affair to be brought to the knowledge of St Clement-the then occupant of the See of Rome-in order that he might allay the disturbance. This Clement is mentioned by St Paul. ${ }^{1}$ The Pontiff at once proceeded to exercise his supreme authority, and wrote an Epistle to reprove the Corinthians. This Epistle is described by St Irenæus as "most powerful," and by Dr Lightfoot as "almost imperious." In it 
Clement claims divine right to intervene in the sedition, and to call the rebels to order. "If any disobey," says Clement, "the words spoken by God through us, let them know that they will entangle themselves in transgression. . . . You will cause us joy and exultation if you obey the things written by us through the Holy Spirit."1

This Epistle was held in so great reverence by the Corinthians that it was frequently read during the Sunday service for many years afterwards. But why this appeal to distant Rome, at a time, too, when St John still occupied the See of Ephesus? Surely for this reason, that the jurisdiction of Rome was regarded as universal; whereas that of Ephesus was not. ${ }^{2}$

Later on, in the year 170, Dionysius, Bishop of Corinth, wrote to Pope Soter: "To-day we have passed the Lord's holy day, in which we have read your Epistle, in reading which we shall always have our minds stored with admonitions, as we shall also from that written unto us before by Clement." ${ }^{3}$ The

'Epist. i. ad Corinth. c. i. 47, 57, 58.

2 Kenrick, "The Primacy," p. 132.

3 Allnatt, "Cathedra Petri," p. 82. St Irenæus distinctly states also that the Epistle was written by Clement, although it is aent in the name of the Church of Rome, adv. hore, c. iii. 
Corinthians were manifestly not anti papal.

(2) About the year 190 the Easter question agitated the churches of Asia Minor. Some years before, Polycarp, Bishop of Smyrna (a disciple of St John), had gone to Rome, and had discussed the matter with Pope Anicetus. Now, however, Pope Victor resolved on procuring uniformity, even by recourse to severe measures, should it become necessary. Accordingly, a letter was sent from Victor to the Bishops of Asia, exhorting them to convene synods in order to bring about the desired change. In obedience to the Pope this was done; but Polycrates, Bishop of Ephesus, persisted in defending the ancient usage, in consequence of which St Victor threatened the disobedient Orientals with excommunication. Irenæus, however, intervened and implored the Pope not to use the sword of separation for the sake of an observance which Anicetus, his predecessor, had wisely tolerated. Although the excommunication was probably never carried into effect, resistance was shown; but no question was raised as to the Pope's right to interfere in Eastern affairs, for at that time 
no one doubted his authority. Thus in the second century, during the very infancy of the Church, we have evidence that the Bishop of Rome not only claimed, but actually exercised, jurisdiction over the Bishops of Asia. ${ }^{1}$

(3) Passing on to the following century, we find that in the year 268 Pope Dionysius also considered it his duty to interfere in Eastern affairs by condemning the heresy of Sabellius, and by excommunicating Paul of Samosata, the heretical Bishop of Antioch. ${ }^{2}$

(4) Again, in the year 341, St Athanasius, Patriarch of Alexandria, appealed to Pope Julius II. from an unjust decision of the Eastern bishops, and the Pope actually reversed the sentence. Socrates thus speaks of the action of the Pope towards Athanasius and those accused with him: "The Roman bishop admitted them to communion; and as by the dignity of his See the care of all devolved on him, he restored to each his own Church." 3

(5) In the year 404 St John Chrysostom appealed to Pope Innocent I. for redress,

${ }^{1}$ Kenrick, "The Primacy," p. 134; and Chapman, "Catholic Claims," p. 67.

2 Murphy, "Chair of Peter," p. 110.

socrates, E. H., lib. ii. c. 15. 
because he had been driven from his See of Constantinople, and the Pope complied with the request.

(6) When, in the year 449, Theodoret, Bishop of Cyrus, in Syria, appealed to Pope Leo I., he used the following words:- "I await the decision of your Apostolic See, and beseech and earnestly entreat your holiness to succour me, who appeal to your right and just jurisdiction."

(7) In the year 492 Pope Gelasius I. wrote an Epistle to the Bishops of Dardania, in Asia Minor, to caution them not to communicate with the Eutychians. This is their reply: "Before receiving your orders we have avoided, as a pestiferous contagion, communion with Eutychus . . . and much more now, after the admonition of the Apostolic See, is it necessary we should keep ourselves from such pollution.... And should any think of separating themselves from the Apostolic See, we promise to shun all communion with them." 1

From these few instances the reader may gather that bishops of great sanctity and learning, dwelling in remote parts, outside

${ }^{1}$ Murphy, "Chair of Peter," p. 120. 
the confines of the Western Patriarchate, considered they possessed the right to appeal from the decisions of their own ecclesiastical superiors to the supreme judgment and arbitration of the successor of St Peter in the See of Rome. 


\section{CHAPTER XII}

THE FATHERS AND PAPAL SUPREMACY

BELIEF in papal supremacy is not only demonstrated by the exercise of the appellate jurisdiction of the Holy See, but the doctrine is plainly stated in the writings of the Fathers.

(1) St Ignatius, A.D. 107, in addressing the Church at Rome, calls her the "one which presides in the country of the Romans, allgodly, all - gracious, all - blessed, all - praised, all-prospering, all-hallowed, and presiding in the covenant of love." It should be noticed that the word rendered preside, when used in two other places by Ignatius, implies superior dignity. In his letters to other churches, instead of the word presides, the Saint employs the simple $i s^{1}$

(2) St Irenæus, A.D. 178, a disciple of a disciple of St John, thus speaks of the supremacy of the Church at Rome: "For with this Church [of Rome], on account of her more powerful headship (propter potenti-

$$
{ }^{1} \text { Allnatt, "Cathedra Petri," p. } 70 .
$$


orem principalitatem), it is necessary that every Church - that is, the faithful everywhere dispersed - should agree [or be in communion with]." 1

This passage is so manifestly a proof of papal supremacy in the earliest Christian times that opponents have brought to bear upon it all the arts of criticism in order to evade its obvious meaning. Let the reader bear in mind that St Irenæus, although a Greek, settled in southern Gaul, where his Church exercised considerable influence over the early missions to Britain and Ireland.

(3) St Cyprian, A.D. 248, calls the Roman Church in which is the See of Peter "the chief or ruling Church, whence the unity of the priesthood has its source." 2

(4) St Hilary with the Council at Sardica, A.D. 344: "This will seem to be best, and by far most congruous, if the priests of the Lord, from each of the several provinces, refer to the head-that is, to the See of the Apostle Peter." 3

1 "Cathedra Petri," p. 70, vide also Allnatt's "St Irenæus," Catholic Truth Society. It may be remarked that Professor Harnack accepts "the modern Roman Catholic" interpretation of this passage, vide Guardian, 22nd Nov. 1895. Consult Chapman, "Catholic Claims," p. 64.

2 "Cathedra Petri," p. 73. $\quad{ }^{3}$ Epist. Sardic. Concil. ad Julium. 
(5) St Ambrose, A.D. 385, tells us : "They have not Peter's inheritance who have not Peter's Chair." And again: "Those, therefore, whom your holiness has condemned, know that amongst us also they have been, according to your judgment." 1

(6) St Damasus, A.D. 366. - What this Pope says is of special interest, on account of his care of the youthful Ninian while he sojourned in Rome to study Catholic doctrine before setting forth on his mission to Scotland. The words which follow indicate the nature of the teaching St Ninian imbibed in Rome, and afterwards delivered to the southern Picts : "Dearest brethren ... you cease not, as the custom ever has been, to refer all those things which can admit of any doubt to us, as to the Head . . . that, supported by the authority of the Apostolic See, you may not deviate in anything from its regulations. . . . It does with reason concern us, who ought to hold the chief government in the Church, if we by our silence favour error." 2 And to the Council of Constantinople he writes: "Why then do you again

"Waterworth, "The Faith of Catholics," vol. ii. p. 76.

${ }^{2}$ Epist. v. Prosp. Numid. 
require from me the deposition of this same man, who even here by the judgment of the Apostolic Chair, . . . was deposed ?"1

(7) St Siricius, A.D. 384, is also associated with St Ninian, as being the Pontiff who ordained him bishop for his work in Scotland. And what does he say? "I bear the burden of all who are heavily laden; yea, rather in me that burden is borne by the blessed Apostle Peter, who, we trust, in all things protects and has regard to us who are the heirs of his government." In the same letter he calls his See "the Apostolic Rock, upon which Christ constructed the universal Church." 2

(8) St Jerome, A.D. 390, to whom (with St Augustine) Dr Skene alludes as belonging to a Church within which there was no belief in papal supremacy, thus writes to Pope Damasus: “I speak with the fisherman's successor, and the disciple of the Cross. Following no chief but Christ, I am linked in communion with thy blessedness - that is, with the Chair of Peter. On that rock I know that the Church is built. Whosoever

${ }^{1}$ Epist. ix. Synod. Orient.

${ }^{3}$ Epist. i, ad Himer. Episc. Terracon. n. 3, 11. 
eats the lamb out of this house is profane. Whosoever may not be in the ark of Noah will perish in the deluge . . . whosoever gathereth not with thee, scattereth." 1 On another occasion he cries out: "If any man is united to the Chair of Peter, he is mine." 2

(9) St Augustine, A.D. 400, speaks of "the Roman Church in which the Primacy of the Apostolic See has always been in force." 3 And writing with the Fathers of the Council of Milevis, he thus addresses Pope Innocent : "We think that those who entertain such perverse opinions will more readily yield to the authority of your Holiness, derived as it is from the authority of the Holy Scriptures.":4

(10) St John Chrysostom, A.D. 387, writes in his work on the Priesthood: "Why did Christ shed His Blood? That He might obtain possession of those very sheep which He entrusted to Peter and to his successors." ${ }^{5}$

(11) St Celestine, A.D. 423, from whom originated the missions of Palladius and

1 Epist. xv. ad Damas. Pap.

${ }^{2}$ Epist. xvi. What St Jerome and St Augustine held regarding papal supremacy is strongly brought out by Dom J. Chapman in his "Bishop Gore and the Catholic Claims," chap. vi. "The Growth of the Roman Cliurch."

${ }^{3}$ Epist. xliii. 4 "Cathedra Petri," p. 109.

${ }^{5}$ De Sacerd. lib. ii. n. 1. 
Patrick, speaks thus: "We, in a special manner, are constrained by our charge, which regards all men-we, on whom Christ has in the person of holy Peter the Apostle, when He gave him the keys to open and to shut, imposed as a necessity to be engaged about all men." 1 And again: "Placed as we are by God on a watch-tower . . . our spiritual care fails not as regards places however distant, but extends through all places where the name of God is preached." ${ }^{2}$ If that is not claiming universal jurisdiction, it is impossible to understand what words mean.

(12) St Cyril of Alexandria, A.D. 444, thus speaks of Pope Celestine: "Let us produce a witness . . most worthy of faith, a most holy man, and archbishop of all the habitable world-that Celestine, who is both Father and Patriarch of the mighty city of Rome." 3 A wonderful testimony, coming, too, from an Eastern bishop on the occasion of his eulogy on the Blessed Mother of God.

(13) St Leo I., A.D. 440, thus praises Rome: "O Rome... that by the See of Blessed Peter, made the head of the universe,

${ }^{1}$ Epist. iii. ad Episc. Illy.

${ }^{2}$ Epist. iv.

${ }^{3}$ Encom. in 8. Mar. Deip. Migne, P.G., Ixxvii. col. 1039. 
thou mightest rule more widely by divine religion than by earthly empire . . . the first of all the Sees ... the Head . . . that See which the Lord appointed to preside over the rest." 1

The same Pope, writing to the Gallican bishops, says: "Let your fraternity agree with us in acknowledging that the Apostolic See, in accordance with the reverence due to it, has been by innumerable reports consulted by the priests of your province also; and that, as ancient custom required, your judgments have been either rescinded or confirmed, by means of appeals in divers causes."

Relative to the same subject may be quoted the following words of St Leo:- "For then, in fact, will the peace of the churches be everywhere preserved, if the universal Church acknowledge its ruler. . . . This do we decree as $^{\circ}$ an unchangeable decision, that it is not lawful, whether for the Bishops of Gaul, or for those of other provinces, to attempt anything whatsoever against ancient custom, without the authority of the venerable Pope of the eternal city." 3

\footnotetext{
1 Serm. Ixxxii. and Epist. cxx.

${ }^{3}$ Epist. x. ad Episc. per Prov. Viennens.

${ }^{3}$ Constit. Valentin. iii. Aug. inter Ep. Leon. xi. 
The bishops of the province of Tarragona, in Spain, wrote in the following terms to Pope Hilary, A.D. 461 :-_ As, therefore, these acts of presumption which divide unity, which make a schism, ought to be speedily met, we ask of your See that we be instructed by your Apostolic directions as to what you would have to be observed in this matter." 1

This accumulative evidence, in favour of papal supremacy, from the writings of the early Fathers, may be fittingly brought to a close by quoting the Formula of Pope Hormisdas, which was subscribed by the Eastern emperor, patriarchs, and bishops, A.D. 519, and confirmed by the Fathers of the Eighth General Council. It was formulated, therefore, before St Columba was born, the belief of both East and West, and is expressive of the doctrine of the whole Catholic Church, of which the Celtic formed part:

"In the Apostolic See the Catholic religion has always been kept undefiled, and her holy doctrine proclaimed. Desiring, therefore, not to be in the least degree separated from the faith and doctrine of that See, we hope that we may deserve to be in the one com-

1 See Waterworth, "Faith of Catholics," vol. ii. p. 104. 
munion with you, which the Apostolic See preaches, in which is the entire and true solidity of the Christian religion, promising also that the names of those who are cut off from the communion of the Catholic Church-that is, not consentient with the Apostolic See-shall not be recited during the sacred Mysteries. This, my profession, I have subscribed with my own hand, and delivered to you, Hormisdas, the holy and venerable Pope of the city of Rome." 1

1 Form. Hormisd. Episc. Orient. Præscript., vide "Cathedra Petri," p. 92. 


\section{CHAPTER XIII}

PAPAL INFALLIBILITY

Closely allied to the subject of the Primacy is the question of papal infallibility. A vast amount of misunderstanding exists concerning it. Infallibility is not inspiration, neither has it any connection with impeccability or immunity from sin in any shape or form. Catholics are often reminded that there have been in the past what are termed "bad Popes"; indeed, we are sometimes given to understand that moral depravity was a characteristic of the Roman Pontiffs. This, of course, is an unwarrantable calumny. The Popes, as a rule, have been men of singular virtue and holiness. It is, nevertheless, true that there have been four or five Pontiffs whose lives are a cause of sadness to Catholics ; but, as will presently be pointed out, infallibility is absolutely distinct from personal holiness. It is, however, remarkable that, out of the long line of occupants of the papal chair, many are honoured as 
martyrs, and seventy-nine are venerated as saints. ${ }^{1}$

But what is meant by papal infallibility? The Vatican Council thus defines it: "The Roman Pontiff, when he speaks ex cathedra - that is to say, when in the exercise of his office of Pastor and Teacher of all Christians he, in virtue of his supreme authority, defines that a doctrine on faith and morals is to be held by the whole Church-by the assistance of God promised to him in the person of Blessed Peter, has that infallibility with which it was the will of our Divine Redeemer that His Church should be furnished in defining a doctrine on faith or morals, and that, therefore, those definitions of the Roman Pontiff, of themselves, and not through the consent of the Church, are irreformable." 1

It is clear, therefore, that the Pope is neither a maker of divine law nor an author of revelation. At the beginning of the Church the full revelation was made by our Lord, part of which was afterwards committed to writing by inspired authors;

'Rev. Sydney Smith, "Papal Supremacy and Infallibility"; a C.T.S. publication.

${ }^{2}$ Sess. 4. c. 4. 
but the guardianship of the entire deposit of faith was committed to the authorised rulers of the Church, of whom St Peter is chief.

If the facts of revelation and a divinely established Church be granted, it follows, as a matter of course, that there must be some means provided for the transmission of the truths of faith, inviolate, to all men throughout all ages; otherwise revelation would be useless, and the end for which it was made frustrated.

The following apposite quotation, from a work by Bishop Hedley, summarises this important question of infallibility. "In the New Testament," says the Bishop, "we have the outlines of a teaching Church instituted by Christ ... a revelation ... this revelation given to the human race by human instruments, and handed on from one human hand to another. God must specially interfere to protect it, or it will be exposed to danger of obscuration, of diminution, or of alteration, as human brains and heads are likely to occasion. In other words, there must be preservation from error, and a development of truth, for what would be 
the use of revelation unless those things went with it? For what is the difference to me between a revelation that is mainly doubtful and one which does not exist? What of the thousands and millions who have not the time nor the ability to study? Revelation was made for them also. And unless I can be practically certain of every point in it, I do not understand why $\mathrm{He}$ should have given it at all. This does not mean that every individual should, or could, be acquainted with every detail of the divine message, but there must be no portion of it which, given the occasion, a secure certainty could not be arrived at. But the general Protestant mind tolerates doubt. On the other hand, there could not be revelation without some kind of development. The Catholic Church has always taught that religious truths, as expressed from the beginning, contain much more than the ordinary mind takes in at once. These implicit truths are brought out and made explicit as time goes on. Every mind has questions to put, and every reasonable question demands, and should have, a reasonable answer. And 
when that right answer is given, that very answer lends itself to further questioning, and thus the divine edifice of Catholic teaching is built up. God's revelation must always be a living revelation, meeting the questions of every generation and the requirement of every century.

"No possible Bible could have contained the answers to all possible questions. When I ask: 'What must I do to be saved?' you cannot send me to dead print. You must send me to a living authority, which can interpret the formularies of revelation. Hence the existence, by divine institution, of infallibility.

"Protestantism, by its unreasonable worship of the Bible, has always tended to discredit Christianity itself, by making men either refuse to accept the mysteries of the Bible, or, as now, driving them to question, as they please, the inspiration of anything whatever that the Bible contains. So that the good old sound Protestantism, which never was strong in logic or argument, only survives in those classes whose inherited prejudice is undisturbed by such a thing as reflection, and it is chiefly kept 
alive by onslaughts on Popery. For everything like reflection is fatal to Protestantism, because although its great watchword, 'The Bible only,' sounds wonderfully satisfying, the moment you attempt to apply it to any book, chapter, or verse of the Bible, then the confusion begins ... an inquirer is reduced to the choice between two alternatives-either he must admit that, out of all that Christ and His Apostles have left us, he can grasp with certainty only a few shreds and scraps, or he must accept the Catholic principle, and submit to the Catholic Church." 1

Infallibility is, therefore, a correction of error, and an enemy to uncertainty concerning the truths of revelation. "It is a supply for a need," writes Cardinal Newman in his Apologia, "and it does not go beyond the need. Its object is, and its effect also, not to enfeeble the freedom and vigour of human thought, but to resist and restrain its extravagance."

The Protestant theory, that the reading of God's word, accompanied by prayer, suffices for ascertaining the true meaning

"Hedley, "The Light of Life," p. 17. 
of revelation, completely breaks down in practice; for, instead of one infallible and divinely appointed guide, it substitutes individual inspiration, which is manifestly preposterous.

Having been endowed with the gift of infallibility, the Catholic Church is able to teach to all men, in all times, the truths of faith unerringly-a gift which is naturally the dowry of only a divinely founded and constituted religion.

Catholics hold that the gift of infallibility resides in the whole body of the Episcopate - successors of the Apostles-united to the Roman Pontiff-successor of St Peter. It is also the teaching of the Church, as is clear from the wording of the Vatican Decree, that the gift of infallibility is assured by God in a special manner to the Pope, under the restrictions and limitations there laid down. It is a gift granted by Christ, not for the personal advantage of the Pontiff, but for the general good of mankind. So long, therefore, as there are souls to be saved, so long will infallibility remain with the successors of St Peter.

Infallible decisions, however, are com- 
paratively rare. If an opinion is clearly supported by the words of Holy Scripture, or is held generally by the Church, as being of faith, there is no need for the Pope to intervene. But should a dispute arise regarding the meaning of a certain teaching of Holy Scripture, the question would be referred to the Pope for final judgment. The Pontiff, of course, is aware that, in his ex-cathedra decisions, he cannot lead the faithful astray in faith or morals because of the divine guarantee; nevertheless, he is bound to use his natural powers to the best of his ability before pronouncing a final definition. Therefore there will be much prayer for guidance and light; there will be study, consultation, and the like. But when once the definition is pronounced, of its very nature it is final and irrevocable, because infallible. ${ }^{1}$

\footnotetext{
2 Fr. S. F. Smith, " Papal Supremacy and Infallibility," wherein it is also shown that papal infallibility is reasonable, and not a "stultification of reason," as some people are fond of asserting.
} 


\section{CHAPTER XIV}

SCRIPTURE AND PAPAL INFALLIBILITY

But, it will be asked, is there any foundation for this doctrine in Scripture? Let us refer again to the words of Christ: "Thou art Peter, and upon this rock I will build my Church, and the gates of hell shall not prevail against it." ${ }^{1}$, The Church of which our Lord speaks is not a lifeless, immaterial edifice, but a body of living men; and it is that Church which $\mathrm{He}$ declares to be built on Peter, and to be proof against errorthe gates of hell. If the foundation is not secure the building will eventually fall. This ruin is provided against by making Peter's faith infallible.

Then, again, the following passage from St Luke is to the same purpose. Our Lord says: "Behold Satan hath desired to have you [my Apostles] that he may sift you as wheat, but I liave prayed for thee [Peter] that thy faith fail not, and thou ${ }^{3}$ Matt. xvi. 18. 
being once converted, confirm thy brethren." 1 Here let it be carefully noted that our Lord prays only for Peter-and why? Because he was to be the supreme teacher of the Church. Christ prayed for two things-(1) that Peter's faith might not fail; (2) that Peter might confirm the brethren in the faith. The prayer of Christ is always heard and answered, therefore we know for a certainty that Peter's faith will always remain firm and true.

Moreover, by special commission, the whole flock of Christ's fold was divinely given over to Peter's care: "Feed my lambs, feed my sheep." 2 Thus Peter became the shepherd of shepherds. It is his duty to feed the whole flock. Now, in the language of Scripture the revealed doctrine of God is often spoken of under the metaphor of food $^{3}$; St Peter will, therefore, be liable (like other human shepherds) to lead the sheep into the poisonous pastures of error (to their ruin) unless the Chief Pastor, Jesus Christ provides, as $\mathrm{He}$ can, that $\mathrm{His}$ Vicar shall not be deceived.

${ }^{1}$ Luke xxii. 31, 32.

2 John xxi. 15-17.

${ }^{3}$ Cf. 1 Cor. iii. 2 ; also 1 Peter ii. 2 ; r. 2. 
It has already been pointed out that Christ founded His Church to endure through all times. But as this visible Church is a successive body of men, it follows that the supreme headship and the infallible teaching must also be successive, otherwise the end for which the Church was established would be frustrated. Therefore it is Catholic teaching that all the successors of St Peter (in their ex-cathedra definitions) are immovable teachers of divine truth, against whom the "gates of hell" will never prevail. 


\section{CHAPTER XV}

THE WITNESS OF TRADITION TO PAPAL INFALLIBILITY

THE proof of papal infallibility from tradition is very full, but it is impossible to give more than a mere sketch of it in these pages. However, it must be borne in mind that, although the doctrine is so clearly set forth in the writings of the Fathers and the decrees of Councils, its formulation under the particular name of infallibility is not ancient. A formulation of this kind is the result of scientific study, to which controversy, more than anything else, gives rise. ${ }^{1}$

The doctrine has come down to us enshrined in such formulas as these:

1. That the Pope is the supreme teacher of the Church.

2. That no one can reject his teaching without sin, and without incurring the penalty of excommunication.

3. That in the See of Peter at Rome the

${ }^{1}$ Cf. the term Transubstantiation. 
sacred doctrine has ever been preserved intact.

4. That this prerogative is derived from St Peter, whose own faith was confirmed by our Lord, that he might confirm the faith of others. ${ }^{1}$

The following quotations from the early Fathers bear witness to the belief of primitive times:

1. St Irenæus says: "By this same order, and by this same succession [of Roman Pontiffs], both that tradition which is in the Church from the Apostles, and the preaching of the truth, have come down to us. And this is a most full demonstration that it is one and the same life-giving Faith, which is preserved in the Church from the Apostles, and handed down in truth." 2

2. The formula of Pope Hormisdas, signed by the Easterns in the year 519, has this expression: "In the one communion with you, which the Apostolic See preaches, in which is the entire and true solidity of the Christian religion." 3

3. St Cyprian thus speaks to the Pope:

1 Father S. Smith, "Papal Supremacy and Infallibility."

2 Adv. hures, iii. c. $2 . \quad 3$ "Cathedre Petri," p. 92. 
"The Chair of Peter and the ruling Church, whence the unity of the priesthood has its source, and to which heretical perfidy cannot have access." 1

4. St Ambrose, speaking of his brother Satyrus, says: "He called the Bishop to him, and not accounting any grace true which was not of the true faith, he inquired of him whether he agreed with the Catholic Bishops-that is, with the Roman Church." ${ }^{2}$

5. St Jerome asks: "What does he [Rufinus] call his faith? That which is the strength of the Roman Church, or that which is in the volumes of Origen? If he answer 'the Roman,' then are we Catholics." "3

6. St Peter Chrysologus writes: "Blessed Peter, who lives and presides in his own See, gives the true faith to those who seek it. For we, in our solicitude for truth and faith, cannot without the consent of the Roman Church hear causes of faith." ${ }^{4}$ These words of St Chrysologus express the belief of Christendom at the period when St Patrick was entering upon his mission to

1 Epist. lix. ad Cornel.

2 De excessu Frat. Migne, P.L., xvi. p. 1362.

3 Adv. Ruff. i. 4. Migne, P.L., xxiii. p. 418.

$\$$ Ep. ad Eutech. 
Ireland. The same doctrine was unhesitatingly proclaimed a few years later by the Council of Chalcedon, when, after listening to the letter of Pope Leo, all the assembled Fathers, with one accord, cried out: "Peter hath spoken by Leo." 1

7. St Augustine, and other African bishops, writing to Pope Innocent $I$. to solicit his confirmation of two Councils-Carthage and Milevis, in which the Pelagian heresy had been condemned-say: "We do not pour back our streamlet for the purpose of increasing your great fountain; but . . . we wish it to be decided by you, whether our stream, however small, flows forth from that same head of rivers whence comes your own abundance." 2

Lastly, three African Councils, in their synodical letter read in the Council of Rome, under Martin II., A.D. 646, declare: “By ancient discipline it is ordained that whatsoever be done, even in provinces remote and afar off, shall neither be treated of nor accepted unless it be brought to the knowledge of your august See, so that a just sentence may be confirmed by its authority,

1 Sess. 11.

${ }^{2}$ Ep. clxxvii. 19. 
and that the other churches may thence receive the original preaching as from its native source, and that the mysteries of saving faith may remain in uncorrupt purity throughout the various regions of the world."1

Papal infallibility, as every one knows, was not defined till modern times, but the act of defining was only a judicial pronouncement to close a controversy. To conclude that a doctrine is new because its definition is recent is as absurd as to imagine that a law is new because a judge adjudicates on a disputed point of the same.

In defining the doctrine of papal infallibility, the Church has but pursued the same course that she followed with regard to the doctrine of Christ's divinity at the Council of Nicæa in the fourth century. Arius denied the doctrine, and the Church closed the controversy by her formal definition. No one, however, would be so foolish as to suppose that belief in our Lord's divine nature then took its origin. The same might be said of the doctrine regarding the divinity of the Holy Ghost, and similar truths generally accepted by Protestants.

1 “Cathedra Petri," p. 99. 


\section{CHAPTER XVI}

OBJECTIONS TO PAPAL INFALLIBILITY

THE four principal objections generally alleged against the Catholic doctrine of papal infallibility are as follows:-

1. St Peter denied Christ. Yes; but at the time of his fall he had not received the commission to feed the flock of Christ, and, therefore, was not yet constituted the Supreme Pastor. It may be that our Lord's words to Peter, "thou being converted," indicate the time when his office was to commence. Besides which, when St Peter told the doorkeeper that he "knew not the man," he was not uttering a dogmatic statement, but only manifesting his own private weakness.

2. Pope Liberius is said to have subscribed a heretical formula. This he did not do. In the formula there was nothing positively heretical-but there was the omission of the word Consubstantial. And at the worst, the Pontiff signed under compulsion, and there 
is no pretence that he taught Arian doctrine ex cathedra.

3. Then Pope Honorius was condemned by the Fourth General Council of Constantinople. Not, however, as a heretic, in the technical sense of the word, but rather as having, through his neglect, indirectly permitted the spread of heresy, and so being involved in the same condemnation as the heretics themselves. The letter which he wrote to the Monothelite Patriarch was not sufficiently firm, but it cannot be shown that heresy was contained therein; and, even were it otherwise, it was a purely private document, and neither in form nor substance did it purport to be an instruction for the Universal Church.

4. Was not the doctrine of Galileo condemned, but afterwards accepted? The Pope himself did not act in this matter. The Roman Congregations condemned; but the gift of infallibility cannot be delegated to any other person, for it is inherent in the papal office alone. ${ }^{1}$

Thus in every instance where an objection

1 Father Coupe, S.J., "Alleged Failures of Infallibility." Catholic Truth Society. 
has been urged against the Catholic doctrine of papal infallibility, it will be found on examination either that the teaching was not ex cathedra, or that it cannot be proved to have been heretical. 


\section{CHAPTER XVII}

THE POPE'S TEMPORAL POWER

Although the question of the temporal power of the Pope has no practical bearing upon the faith of the Celtic Church, nevertheless it may be well to add a short explanation in order to remove possible misunderstanding.

The Catholic Church being the visible kingdom of God upon earth, it follows that Christ's Vicar, the Head of that Church, should occupy a position which will enable him to guide, rebuke, and teach all men, and thus further the work of God in the world. The Pope does not claim to be the temporal ruler of the whole world, as some persons have foolishly imagined, but what he does claim is freedom from every authority outside himself. The free exercise of his high office becomes impossible when the Pope is the subject of another ruler.

The immunity of the Pope from the tribunals of the civil power should be ab- 
solute, and this immunity must extend to the cardinals and others who are around the Pontiff, and without whose aid it would be impossible to govern the Church. This absolute independence of every civil Government is, moreover, imperative, in order to remove any distrust that might otherwise arise in the minds of the Pope's 250,000,000 spiritual subjects, belonging, as they do, to every country of the world.

There is no comparison between the Pope's influence and, for instance, that of the Churches of England, Scotland, or Russia, for these institutions are State institutions, professing loyalty to their respective Governments. The Pope's authority, on the other hand, extends to every land, and affects the well-being of all Governments.

As a result of military force, less than halfa-century ago, the Pope was deprived of his territory, to which, in the opinion of the Catholic world, he had a right under a title much older, and certainly more valid, than that of any other European sovereign. Personally, the Pope may care very little about the possession of this or that amount of territory; but he is the trustee for the 
Catholic world, and must, therefore, look beyond the narrow limits of the Italian nation. All Catholics claim to be the beneficiaries in the religious trust which the Pope is called upon to administer, and, therefore, he cannot relinquish his title.

Among Catholics, the Roman Pontiff claims and exercises spiritual jurisdiction in religion and morals. He does not interfere with politics unless they break through the rules of morality.

The Pope, then, in the eyes of Catholics, must be a sovereign, or the Church will be a subject. It is in the design of God that His Church should be free, and, therefore, it is impossible for the Pope ever to abandon his claim to sovereign independence. ${ }^{1}$

${ }^{1}$ For fuller information on this subject the reader is directed to Cardinal Gibbon's " Eaith of our Fathers," p. 163 ; also to Dr Barry's "Papal Monarchy" (Story of the Nations Series). . 



\section{PART II}

\section{CELTIC CHRISTIANITY}





\section{CHAPTER I}

EARLY MISSIONS FROM ROME

Having explained the nature of the Papal Claims, and afforded proof that the Supremacy of the Bishop of Rome, the successor of St Peter, has always been acknowledged as of divine right in the Catholic Church, attention may now be directed to the manner in which that supremacy was exercised and acknowledged in early ages among the Celts.

Some uncertainty exists as to when and how Christianity found its way into Britain. The most probable opinion suggests that, during the occupation of the country by the Roman legions, a knowledge of the true Faith was diffused among the Celtic inhabitants by means of Christian soldiers. Be this as it may, evidence exists of seven different missions to these countries during early times-all of which emanated from Rome.

(1) About the year 177 a British king, named Lucius, sent Elvan and Medwin to 
Pope Eleutherius in order to obtain instruction in the Christian faith, so that they might become teachers in their native land. Accordingly they were instructed and ordained. On their return to Britain they received from the Pope, as companions in their Apostolic labours, St Fugatius and St Damian. The measure of the success of their preaching among the British we do not know; but churches still exist in the neighbourhood of Llandaff, bearing the names of Llearwg (Lucius), Dyfan, Ffagan, and Medwy-thus bearing witness to the truth of the ancient tradition.

St Irenæus, in his work "against heresies," has told us explicitly what was held concerning papal supremacy at the time when Elentherius was the occupant of Peter's Chair. He says that every church must be in communion with the Roman See, because of her headship. ${ }^{1}$ The Pope of the time was not likely to be less papal than a bishop in Gaul ; it may, therefore, be rightly inferred that the papal envoys to Britain introduced the doctrine so clearly stated by St Irenæus. 
Among non-Catholic writers it has become customary of late to cast discredit on this mission from Pope Eleutherius. The work bearing the name of Haddan and Stubbs is accountable for much of this kind of destructive criticism. Mr Haddan insists that the legend rests solely upon a later form of the "Catalogus Pontificum Romanorum," written about the year 530. ${ }^{1}$ This, however, is not the case, as has been demonstrated by the late Father Anderdon in his interesting and valuable work, "Britain's Early Faith."2

(2) The second mission was to Caledonia. Its evidence may not stand so high as that for the mission of Pope Eleutherius, but this is hardly sufficient reason for relegating it to the region of myth and fairy tale. Fordun, ${ }^{3}$ and several other Scottish authorities relate that about the year 203, at the request of a king named Donald, Pope St Victor sent into Scotland the missionaries Marcus and Dionysius. More than this they do not say; but Tertullian's statement, that the parts of

1 Haddan and Stubbs, vol. i. p. 25.

2 Preface, p. ix.

${ }^{3}$ See also note, p. 404, vol. ii. "History of Catholic Church in Scotland," Bellesheim. Trans. by Dom. O. Hunter Blair, O.S.B. 
Britain into which the Romans had never penetrated had been made subject to Christ, may well be taken as referring to some portion of Caledonia to which the mission from Pope Victor had been sent. ${ }^{1}$

Another remarkable testimony in favour of this old tradition, and one which was certainly unintended, exists in the ancient Culdee Litany quoted by Bishop Forbes in his "Kalendars of Scottish Saints." 2 In this Litany, after the names of the martyrs, the list of bishops commences with "S. Victor Papa Romane"; then comes "S. Cœlestine Papa Romane," followed by St Martin, St Ninian, St Palladius, St Servanus, and St Patrick. Why, it may be asked, should these two Popes only be selected for special veneration, except for the local benefits they had conferred? Celestine sent Palladius and Patrick; but why should Victor head this list, or be mentioned at all, if he sent no one?

Granted that a mission did originate with St Victor, it is well known, from the acts of that Pontiff, what the nature of the theology must have been which found its way into Caledonia in the year 203. Pope Victor was

1 Tertull. adv. Judeo. vii.

2 Haddan and Stubbs, ii. p. 279. 
so convinced of the fact that his jurisdiction extended over the whole of Christendom that he threatened, to excommunicate the Asiatic Christians, and no one was found to deny that he had the right so to do. 


\section{CHAPTER II}

BRITISH BISHOPS IN PAPAL COUNCILS

Whatever may have been the nature or extent of the missions attributed to Popes Eleutherius and Victor, there is no question about a fully organised church existing in Britain in the year 314. In that year three bishops were sent from Britain to take part in a Council assembled at Arles, presided over by the legates of Pope St Sylvester. These prelates sat as colleagues of the bishops from other parts of Christendom, and assented to its Canons, one of which decided that the feast of Easter be celebrated on the day fixed by papal authority. Moreover, these bishops joined with the Fathers of the Council in begging the Pope to send round "the customary letters," announcing the result of their deliberations. The Pontiff is addressed by all as the "Most beloved Pope Sylvester," and they affirm that, "abiding in the common link of charity, and in the bond of the unity of their Mother, the Catholic 
Church," they salute him, "the glorious Pope, with deserved reverence." In conclusion, they express their regret that the Pope was not with them in person. At the same time they say that they realise that "he could not absent himself from the place where the Apostles daily sit, and where their blood without ceasing attests the glory of God." 1

Bishops from Britain, again, attended the General Council of Nicea, A.D. 325. In connection with this Council, the Emperor Constantius mentions that the Church of Britain agrees with Rome regarding the date of the feast of Easter.

Later on, A.D. 347, British bishops sat in the Council of Sardica, in Illyria, and assented to its decrees, whereby St Athanasius was exonerated from the charges brought against him. In this same Council, it is important to note, provision was made relative to appeal to the Pope-an enactment which afterwards became embodied in the famous Canon of St Patrick in the Book of Armagh. The decree runs thus: "It would seem to be

1 Anderdon, “Britain's Early Faith," p. 71 ; also Gasquet, "Short History of the Catholic Church in England," p. 9. 
the best and most proper course for the priests of the Lord from every province to refer to their head-that is, to the See of the Apostle Peter." ${ }^{1}$ At the dispersion of the assembly messengers were despatched to Pope Julius, to give him a full account of the proceedings, and to submit everything to his sanction and approval.

From these three facts two conclusions necessarily follow :-1st, that the British Church was an integral part of the Church Universal, agreeing with other Christian churches in doctrine and discipline; 2nd, that the acts and declarations of these Councils are to be taken as acts and declarations of the British bishops, and, therefore, expressive of the belief and practice of the British Church. We see that from these acts the Fathers of the Councils, and, therefore, the British bishops, looked upon the Bishop of Rome as their head because he was the successor of St Peter the Apostle.

If it be objected that this proves nothing

1 Epist. Synod. ad Julium, Iabbe, ii. p. 661. In reference to this decree Pope Innocent, A.D. 410, says : “If any greater causes shall have arisen, let them, after the episcopal judgment, be referred to the Apostolic See, as the Synod ordained, and a blessed custom demands" (Epist. ii. Vict. Rhotomag). Cf. also Canon of St Patrick, vide "Cathedra Potri," pp. 64, 67. 
more than attributing to the Pope mere primacy of honour, and not of jurisdiction, it may be asked: Why should bishops of every province refer their affairs to a foreign and distant bishop, "as to their head," if that bishop, in that capacity, possessed no jurisdiction or real authority in their respective provinces ? ${ }^{1}$

1 Lingard, "Saxon Church," p. 372. 


\section{CHAPTER III}

\section{ST NINIAN'S MISSION}

To the British Church, which had so fully acknowledged papal supremacy in the Councils of Arles and Sardica, belonged St Ninian. He was born about the year 360 , in Cumbria, which formed part of the Scotland of those days. His father, being a British prince, was a man of no small influence in the country. Fired with a desire to preach the Gospel to his heathen fellow-countrymen, Ninian turned instinctively to Rome, as to the centre of Catholic faith and discipline; and to Rome he went. ${ }^{1}$ There he spent several years in acquiring Christian doctrine in the schools of St Jerome, and under the patronage of Pope Damasus. Having received episcopal ordination from Siricius, the successor of Damasus, Ninian prepared to return to Scotland.

In this place attention may be drawn to 
the desire of non-Catholics to belittle every particle of evidence that tells in favour of the supremacy of the See of Rome. One writer has objected that Bede lived three centuries after Ninian, and that there was a tendency in mediæval times to trace all ecclesiastical enterprise to Rome. ${ }^{1}$ A Protestant Bishop of Edinburgh tells us that Ninian's desire to go to Rome, to gain a fuller knowledge of the Catholic Faith, is comparable to the wish of an intelligent Kaffir youth "to gain the advantages of a theological training that might be had at Oxford or Cambridge, or some other of the centres of Anglican Church life." 2 Suffice it to say that the parity is denied. Rome, as we have seen, was regarded by British Christians as the See of Peter, the occupant of which was the head of the Church, the divinely appointed means of preserving unity. At Oxford the "intelligent Kaffir youth" would find such claims absolutely repudiated by Anglicans, and accepted only by a small body adhering to what has been contemptuously designated the

1 Vide Scotsman, 5th June, etc., 1902.

2 Dr Dowden, "Celtic Church in Scotland," p. 25. 
"Italian Mission." On the contrary, the " intelligent Kaffir" would discover "Anglican Church Life" teeming with divisions and unbelief concerning the actual fundamentals of Christianity-the natural consequence of its breach with the Pope at the time of the so-called Reformation.

On returning to Scotland, St Ninian established himself on the coast of Galloway, where he founded a community, and built a church according to the models he had become familiar with in Rome. On that western shore, at the commencement of the fifth century, there existed a mission from Rome, ruled over by a bishop educated and ordained in Rome; its very church erected after the Roman pattern; and within the walls of that church were duly celebrated the rites of the Latin Church, of which the Pope was the acknowledged Head.

The nature of St Ninian's theology may best be gleaned from the teachings of his masters. St Jerome was one of these. And what did he teach? He asserts that schismatics and heretics rend to shreds the seamless robe of Christ; therefore in matters 
of faith the Chair of Peter must always be consulted. The holy Doctor maintains that Christ's Church has been built on Peter; therefore anyone who partakes of the Eucharist apart from this Church, built on Peter, is a profane man. And those who do not gather with the Pope scatter. "I am in communion with your Blessedness," cries St Jerome to Pope Damasus. ${ }^{1}$ What a different ring all this has from the novel teaching of Luther, Calvin, and Knox, introduced into these countries during the sixteenth century. That teaching, alas! succeeded only too well in rending the garment of Christ, as is manifest from the 200 warring sects that exist in Great Britain to-day.

And what does St Augustine, the contemporary of Jerome and Ninian, say? "The Roman Church," he asserts, "is that in which the Primacy of the Apostolic See has always been in force." 2 Is this Protestantism or "Roman" Catholicism?

The teaching of the Popes under whom St Ninian was trained has already been quoted. St Damasus requires all contro-

${ }^{1}$ Epist. xv. ad Damas. Pap.

2 "Cathedra Petri," p. 65. 
versies to be settled by the Roman Pontiff, because he holds the chief place in the government of the Church. He maintains that he has the power to depose not only Western bishops, but those of the East as well.

Pope Siricius, Ninian's consecrator, affirms that he bears the burdens of all; or rather, in him the burden is borne by St Peter, whose successor he is, and whose authority he possesses. ${ }^{1}$

But the work of St Ninian was not confined to the country south of the Grampians ; his mission is believed, and with reason, to have extended to Ireland also. It is impossible that, living so near to Hibernia, Ninian's influence should not have extended thither. A visit of the Saint to Ireland is commemorated in the Festology of $\mathrm{St}$ Engus, and by other writers also; and it is said that he erected in the northern part of the present county Kildare a church and a monastery resembling those at Whitherne. ${ }^{2}$ Be this as it may, it is indisputable that for several centuries a

1 Epist. i. ad Himer. Tarrac. Eps. n. 1.

2 Cardinal Moran, "Irish Saints in Great Britain," p. 151. 
constant stream of Irish students frequented the monastic school which Ninian had founded in Galloway, and among them must be numbered St Finnian of Moville, the preceptor of St Columba. There, at Whitherne, those Irish scholars learned to revere the memory of St Ninian; and there they were imbued with that doctrine and that discipline which Ninian taught his first disciples, and which he himself had learned in Rome. 


\section{CHAPTER IV}

PAPAL MISSIONS FROM GAUL

During St Ninian's lifetime there arose the heresy called Pelagianism. It concerned the doctrine of Grace, and its author was a member of the Church in Britain during the fifth century. The Pope, as guardian of the faith, excommunicated the false teacher. But let us note the tone of the defence, which Pelagius himself addressed to Pope Innocent, A.D. 402: "This, most Blessed Pope, is the faith we have learnt in the Catholic Church. ... If anything is stated therein not accurately, or guardedly, as it should be, we desire it to be corrected by you, who hold both Peter's faith and Sec. But if this our confession is approved of by the judgment of your Apostleship, then whosoever endeavours to cast blots on me will prove himself either ignorant or malicious, or even not a Catholic, but will not prove that I am a heretic."

${ }^{1}$ Gasquet, "Catholic Church in kngland," p. 10. 
With the spread of Pelagianism troubles arose; and these at length became so serious that Pope Innocent I. commissioned Victricius, himself a Briton, and the then Bishop of Rouen, to cross over to his native land, in order to quell the storm. Victricius, anticipating the difficulty of the work, petitioned the Pope to bestow upon him "the authority of the Roman Church." Innocent replied that, "if any weightier causes come under discussion, let them after episcopal judgment be reported to the Apostolic See as the Synod [of Sardica] lays down, and a blessed custom requires." 1

But the mission of Victricius did not achieve the success that was hoped for; therefore Pope Celestine sent into Britain St Germanus of Auxerre and St Lupus of Troyes. Constantius, who wrote some sixty years after the event, merely mentions that the missionaries were sent by a Council of French bishops; but we have the testimony of a much higher authority, informing us that the mission of Germanus and Lupus was derived from Rome-and that testimony comes from Prosper of Aquitaine, a Gaul

${ }^{1}$ Gasquet, "Catholic Church in England," p. 10. 
by birth, and secretary to the Pope. "From him," says Lingard, "we learn in his Chronicle . . . that in 429, Celestine, at the application of the deacon Palladius, sent Germanus 'in his own place' [that is, as his legate] that he might drive out the heretics, and guide the Britons to the Catholic faith. . . . Prosper does not make this statement once only, but repeats it equivalently in his controversial work against Cassian-where, speaking of Britain and Ireland, he says that Celestine kept the Roman island Catholic, and made the barbarian island Christian." 1

In the year 447 St Germanus visited Britain a second time, accompanied by $\mathrm{St}$ Severus of Trèves. The result was the practical extermination of Pelagianism.

These missions illustrate in a special manner the energetic zeal of the Roman Pontiff for the preservation of the purity of the faith, and the close communion that existed between the British and the Gallic prelates. This close communion leads one to make a practical conclusion--namely, that both Churches recognised the same form of

1 Lingard, "Anglo-Saxon Churoh," p. 374. 
ecclesiastical headship and government, and that, if the Church of Gaul admitted or rejected the supreme authority of the See of Rome, the British Church would admit or reject it also.

To settle this question we again appeal to the testimony of St Irenæus, Bishop of Lyons, in that celebrated passage of his work against heresies, in which the Bishop requires "every church to agree with the Church of Rome, on account of her more powerful headship." 1

Prosper of Aquitaine was a Gaul by birth and education; what he states concerning the authority of the Holy See may be reasonably considered as the common opinion among his fellow-countrymen. And what does he say? Referring to the origin of Pelagianism, he tells us "that Rome, as the seat of Peter, is the head of the Episcopal order in the whole world, and thus holds in subjection, through the influence of religion, more nations than it ever subdued by the force of arms." 2

Furthermore, during the pontificate of

${ }^{1}$ Adv. Hær. L. iii. c. 3.

2 De ingrat. vide "Cathedra Petri," p. 77. 
Leo I. nineteen Gallic bishops wrote to that Pope in favour of privileges belonging to the See of Arles. In their letter they acknowledge that "the holy Roman Church, through the Prince of the Apostles, holds the principality, of headship, over all the churches of the whole world." 1

Can these passages, it is asked, in the name of truth, be interpreted as referring merely to superiority of rank and honour? Surely they indicate, as clearly as language can be expected to do-when not used for the purpose of controversy - that the Church of Gaul admitted, from the second century onwards, the supreme authority and jurisdiction of the Roman Pontiff; and if such was the belief of the Gallic Church, it may be reasonably concluded that it was also the belief of the Church of the Britons.

${ }^{1}$ Lingard, "Anglo-Saxon Church," p. 377. 


\section{CHAPTER V}

MISSION OF ST PALLADIUS

There can be no doubt that Christian communities existed in Ireland anterior to the arrival of St Patrick. The influence of St Ninian's Christian schools at Candida Casa must have made itself felt in the sister isle, even if St Ninian did not visit Ireland in person; but in all probability the papal missionary did go thither.

Colgan accepts the legend that St Kieran, St Ailbe, St Declan, and St Ibar were bishops in Ireland prior to either St Patrick or St Palladius. 1 Ussher, too, is in favour of this story. According to the legend, St Kieran is said to have been born A.D. 352; he went to Rome, where he was baptised and ordained. This would, accordingly, have taken place during the pontificate of either St Damasus or St Siricius - Popes who promoted the mission of St Ninian to the Southern Picts. On account, however, of the anachronisms

${ }^{1}$ Aa. SS. ad 5. Mar. 
with which the legend abounds, it is difficult to accept it (in its entirety) as authentic history. However, one fact remains clear, and it is this, that all these accounts, taken together, bear out in a remarkable manner the tradition that Christianity, whensoever, and by whomsoever, introduced into Ireland, came from Rome.

Before the first half of the fifth century closed Ireland was still mostly pagan. Who could provide for the diffusion of the light of the faith in that distant island beyond the confines of the Roman Empire? For, be it remembered, Ireland was never subjected to Roman rule. Surely it belonged of right to him who "bears the burdens of all"1 the successor of St Peter.

Knowledge of these beginnings of Christianity in Ireland had, doubtless, reached Rome after the mission of Germanus and Lupus to Britain, A.D. 429, and in consequence thereof the Pope deemed it advisable to appoint a bishop over the Irish Christians. We are indebted for this authentic item of information to St Prosper, who held high office in the Roman Church, and who published, about

' Pope Siricius, Ep. i. ad Himer. Tarrac. Ep. 
the year 434, a brief chronicle of the leading facts of history. He thus records the mission from Rome to Ireland: "Palladius was consecrated by $\mathrm{P}_{\mathrm{Q} \text { pe }}$ Celestine, and sent as the first bishop to the Irish believing in Christ." 1

Palladius had already distinguished himself in helping forward the work of freeing Britain from the heresy of Pelagius. "Through the instrumentality of Palladius the deacon," says Prosper, "Pope Celestine sends Germanus, Bishop of Auxerre, in his own stead, to root out heresy, and direct the Britons to the Catholic Faith." 2

That the Popes did exercise their authority very frequently in matters of this kind during the fourth century is clear from the following letter of Innocent I. He says: "Is it not known to all that the things which have been delivered to the Roman Church by Peter, the Prince of the Apostles, and preserved ever since, should be observed by all, and that nothing is to be introduced devoid of authority or borrowed elsewhere? Especially as it is manifest that no one has founded churches for all Italy, the Gauls, Spain, Africa, and the interjacent islands, except such as were

${ }^{3}$ Moran's trans. vide " Early Irish Church," p. 4.

"Ibid. 
appointed priests (or bishops) by the venerable Peter and his successors." 1

The preaching of Palladius did not, apparently, produce much fruit. It is said that he baptised several converts and founded three churches. These beginnings of his apostolate alarmed the pagans, who forthwith proceeded to use violence against him. Palladius withdrew from Hibernia towards the close of the year 431, and after a stormtossed voyage arrived on the coast of Britain on his return journey to Rome. However, before he could carry out his final intention, death overtook him while he still lingered in Scotland. According to Fordun, Palladius died in the district of the Mearns, where to this day the memory of the Saint still survives.

Professor Bury, in his "Life of St Patrick," does not accept the foregoing assertions. He is of the opinion that St Palladius did not abandon Ireland, but, on the contrary, the Picts to whom he went were a portion of his charge, residing not in the north of Britain, but in North Ireland. His mission to Ireland was not cut short by a voluntary desertion of his post, but by death. ${ }^{2}$

${ }^{1}$ Epist. ad Decent. Opera Innoc. Migne, P.L., p. $551 . \quad{ }^{2}$ P. 55. 


\section{CHAPTER VI}

ROMAN MISSION OF ST PATRICK

The Christianity introduced into Scotland by St Columba was the Christianity which, 100 years before, had been delivered to Ireland by St Patrick; hence the extreme importance attached to the origin of the mission of St Patrick.

Laying aside the absurd theory of Ledwich, that St Patrick never existed; as also the laboured contention of Zimmer, that the historical Patrick is no other than Palladius; ${ }^{1}$ we may proceed to consider what has to be said in favour of St Patrick's Roman mission to Ireland, which dates from the year 432.

The tradition of the Irish nation, embodied in documents as ancient as the seventh century, ascribes the conversion of Ireland to

1 These startling theories have been dealt with by (1) Lanigan, "Ecclesiastical History of Ireland," vol. i. c. ii. ; (2) Dr Whitley Stokes, "Tripartite Life," Rolls Series; (3) Prof. G. T. Stokes, "Ireland and Celtic Church." The errors of Prof. Zimmer's book on the Celtic Church are discussed by Dr B. M'Carthy in Irish Ecclesiastical Record, November 1903. Professor Bury also deals with them in his recent "Life of St Patrick." 
one definite person, and that person is $\mathrm{St}$ Patrick. Over and above this, the same tradition affirms unhesitatingly that Rome was the source whence St Patrick derived his mission, for he came with the sanction and authority of St Peter's successor, Pope Celestine. ${ }^{1}$

This tradition, so well authenticated, was never questioned until modern times, when certain writers denied that St Patrick ever had a mission from Rome. But in this denial they rely on a purely negative argumentnamely, that if the Pope had sent him to Ireland, Patrick would have mentioned that fact in the only two authentic writings of his that have come down to us - his Confession and his Letter to Coroticus.

Is this certain? Is it not probable that he omits to mention his mission from the Pope (1) either because it must have been well known to those whom he was addressing; or (2) because his chief object was to vindicate himself against the charge of rashness and presumption in undertaking a great and dangerous work, for which he was not qualified either by education or early train-

'Vide Moran's "Essays on the Early Irish Church." 
ing? In his Confession he admits all this with simple sincerity, attributing his deficiencies in no small degree to his prolonged captivity in Ireland during youth. His defence is that the task put upon him was not by man but by God, that he had a divine mandate to preach in Ireland. He then appeals to the success of his work as a tangible proof that his commission was a divine one.

True, he might have appealed to the fact that, like Palladius, he had received a commission from the Pope to evangelise, but he knew that the work of Palladius had not met with great success; moreover, the work had not been assigned to Palladius in the same remarkable way by God. Patrick claimed the still higher commission of Christ Himself. But St Paul, though authorised by a divine commission to evangelise the Gentiles, "went to Jerusalem to see Peter, with whom he tarried fifteen days," before starting out to commence his work. ${ }^{1}$

If there is no mention of Pope Celestine in the Confession or in the Epistle, neither is

'Lanigan's "History," vol. i. p. 349; also Archbishop Healy's "Insula SS. ct Doctorum," chap. iv. 
there any reference to St Germanus, with whom St Patrick remained for several years in Gaul, yet this fact is admitted by every historian. Patrick does not name the bishop who ordained him, but that does not disprove the fact that he had received episcopal ordination. One fact is noteworthy : he refers to the "Roman saints" as being one with his fellow - countrymen; and he links together the Christians of Gaul and of Rome, as united in the charitable work of sending alms for the ransom of their brethren, who were held in captivity by the Franks. ${ }^{1}$

Dr Todd, in speaking of this matter of mission from Rome, says: "Had he received a regular commission from the See of Rome that fact alone would have been an unanswerable reply." ${ }^{2}$ But, let it be repeated, the accusation was not that Patrick had set out unauthorised, but that he was unqualified for the task. He had accepted the burden imposed on him by Pope Celestine because he had been impelled thereto by divine manifestations. Dr Todd then adduces the rude Latinity of Patrick as evidence that the Saint

'Stokes and Wright, "The Writings of St Patrick," pp. 45, $52,62$.

'Tord, “St l'atrick, A postle of Ireland," p. 310. 
could never have studied in the schools of St Germanus and St Martin. In reply to this objection, Cardinal Moran has clearly shown that Dr Todd fails to understand either the spirit of the school of St Germanus or the humility of St Patrick. ${ }^{1}$

But Dr Todd and his friends have not exhausted their armoury. They tell us that no reference of any kind to a commission from Pope Celestine is to be found in the ancient hymn of St Sechnall, the metrical life of Patrick by St Fiacc, or the famous tract of Muirchu-Maccu-Mactheni ; therefore St Patrick and the early Irish Church were independent of papal jurisdiction. But what do these compositions really say?

(1) St Sechnall's hymn was composed before the year 447. ${ }^{2}$ It commemorates St Patrick's virtues without, however, referring to historical facts. But in the third stanza, if the reading "Petrus" be adopted (as it is in some MSS.), we find St Patrick extolled as being "firm in the faith as Peter, upon whom the Church is built, and of whose apostolate he [Patrick] was made partaker by God." s

Moran, "Early Irish Church," p. 70.

2 Healy, "Insula SS.," p. 77.

${ }^{3}$ Moran, "Early Irish Church," pp. 71, 91. 
Significant, indeed, of a mission from the Pope.

(2) St Fiacc's hymn was also composed during the lifetime of St Patrick. This interesting composition records but few facts of the Saint's career. A mission from Rome is not mentioned, because it was probably taken for granted, seeing that Palladius had received a similar mission but a short time before. ${ }^{1}$

(3) Mactheni's tract dates from the seventh century. It exists in an incomplete form in the Book of Armagh. Fortunately, however, the Bollandists discovered a codex in Brussels containing the entire text of the tract. Father Edmund Hogan, S.J., edited this important document, and published it in the Analecta Bollandiana for the year 1882. The missing chapters from the Book of Armagh, relative to St Patrick and Rome, are thus translated by the late Marquis of Bute:

"He [Patrick] went forth to visit and honour the Apostolic See, to the head also of all the Churches of the whole world, that now knowing the divine and holy mysteries whereunto God called him that he might learn

'Moran's " Early Irish Church," p. 73. 
and understand, and fulfil them, and that he might preach and confer the grace of God among the nations outside, turning [them] unto the faith of Christ.

"5. Of the finding of holy Geraianus [Germanus] in the Gauls, and therefore he went no further.

"When, therefore, he had sailed over the right hand British sea, and started on the journey through the Gallic Alps, to pass through, as he proposed in his heart, even unto the uttermost, he found a certain most holy Bishop in the city of Alsiodorum, the Prince Germanus, a most precious gift. With him he tarried no small while, according to that which Paul was at the feet of Gamaliel, and, in all subjection, and patience, and obedience, with all the desire of his soul, learned, loved, and kept knowledge, wisdom, and chastity, and all useful things not only of the spirit but also of the soul, with great fear and love of God, in goodness and singleness of heart, in strength in body and in spirit." 1

The heading of chapter the fifth: "De inventione sancti Germani in Galliis et ideo

1 "The Now Light upon St Patrick," p. 50, in "Essays on Home Subjects." 
non exivit ultra [or amplius]," has given rise to the theory that St Patrick started for Rome, but meeting St Germanus in Gaul he went no farther. It must be noted, however, as Cardinal Moran points out, that the chapter headings do not follow in chronological order. ${ }^{1}$ Therefore, in view of the unbroken tradition, we may reasonably maintain that at one period of his life St Patrick did really go to Rome, and that at another time he placed himself under the spiritual direction of Germanus, who was Pope Celestine's special representative in Gaul.

The true sequence of facts is probably furnished by Probus, whose life of St Patrick is nothing more than an emendation of Mactheni. The passages from Probus bearing on our subject run thus: "St Patrick poured forth to the Lord the following prayer :

' O Lord Jesus Christ, who hath guided my steps through Gaul and Italy to these islands, conduct me, I beseech Thee, to the seat of the holy Roman Church, that there receiving due authority to preach with confidence Thy word, the people of Hibernia may through my ministry be led to the Christian faith.'

1 Moran's " Farly Irish Church," p. 77. 
"Not long after this, the man of God, Patrick, proceeded as he had desired from Ireland to Rome, the head of all the churches, and there having sought for and received the Apostolic benediction, he returned by the same road by which he had travelled thither.

"Having crossed, however, the British sea, and entered on his journey to Gaul, he came, according to his design, to Germanus, Bishop of Auxerre, a most holy man, most revered for his faith and learning, the illustrious head of all the churches of Gaul; and having remained with him in all submission for no little time in the practice of patience, obedience, charity, chastity, and perfect spotlessness in mind and soul, maintaining his virginity in the fear of the Lord, and persevering in goodness and simplicity of heart, during the whole time of his earthly pilgrimage." 1

There can be little doubt that St Germanus was instrumental in obtaining St Patrick's appointment for the great work of preaching

1 Trans. from Whitley Stokes "Tripartite," p. cxxxix. Stokes suggests that Chapter 20, "Not long after," etc., is an "interpolation." O'Hanlon, however, seems to solve the difficulty when he points out that Chapter 20 is merely misplaced. It should follow Chapter 22 of Probus, where it follows naturally, vide "Lives of Irish Saints," iii. p. 527. 
the faith to the Irish. ${ }^{1}$ That this took place before or after the death of Palladius is immaterial.

Several writers, relying on the evidence of the Tripartite Life of the ninth or tenth century, believe that Pope Celestine himself consecrated St Patrick to the episcopal office. $^{2}$ The more common opinion, however, is that Amathorex was the consecrator. This latter tradition still survives in the Church of Ivrea, in North Italy. The late Archbishop Ullathorne thus speaks of the place he occupied among the Fathers in the General Council of the Vatican, 4th February 1870 : "Behind me is the Bishop of [Torea] Ivrea, in North Italy, who says that his predecessor ordained St Patrick, and that he has the body of an Irish saint in his cathedral." 3

In concluding this chapter, attention may be drawn to the fact that not always did the Roman Pontiffs confer episcopal orders on those whom they sent to preach in heathen

1 Whitley Stokes, “Tripartite," p. 522.

${ }^{2}$ Ibid. p. 31. Note also the following remarkable words taken from MSS. older than the ninth century:- "For it belongs to Peter's successor to benefit Europe" (Stokes, "Tripartite," i. p. 31.)

3 "Letters of Archbishop Ullathorne," p. 222. Torea is evi. dently a misprint. The Irish saint referred to is Blessed Thaddeus MacCarthy. 
countries. St Augustine of Canterbury was directly commissioned by Pope Gregory to evangelise the Anglo-Saxons, yet it was not till some time afterwards that he had to repair to Gaul in order to be consecrated Bishop. If St Patrick received consecration from Bishop Amathorex, it would be a case not dissimilar to that of the Apostle of England.

Professor Bury, in the light of the most recent research, is of opinion that St Patrick was ordained a deacon by Bishop Amator, and that he subsequently received episcopal consecration from St Germanus, Amator's successor. Palladius was consecrated by the Pope first bishop for the Christians of Ireland. "But once this step was taken . . . it was a matter of indifference who consecrated his successor. . . . It was an accident that Patrick was consecrated in Gaul." 1 The following strong passage, from the same author, proves how worthless is the argument that the Celtic Church was independent of, and, indeed, almost antagonistic to, Rome :

- "When a new ecclesiastical province was to be added to Western Christendom, it

1 " Life of St Patrick," p. 65. 
was to Rome naturally that an appeal would be made. It was to the Bishop of Rome, as representing the unity of the Church, that the Christians of Ireland, desiring to be an organised portion of that unity, would naturally look to speed them on their way. His recognition of Ireland as a province of the spiritual federation of which he was the acknowledged head, would be the most direct and effective means of securing for it an established place among the Western churches." " The same learned Professor is of opinion that St Patrick, after eight years of Apostolic labour, went to Rome to give the Pope, Leo the Great, an account of his mission, and also to obtain advice as to the foundation of a metropolitan church. He bore back with him to Ireland relics of the Apostles St Peter and St Paul. ${ }^{2}$

1 "Life of St Patrick," p. 153.

${ }^{2}$ Ibid. 


\section{CHAPTER VII}

EVIDENCE FOR ST PATRICK'S ROMAN MISSION

DR ToDD, though not admitting the Roman mission of St Patrick, says, with all seriousness, that even if such a mission could be proved, it would not by any means follow that the early Church of Ireland depended on the See of Rome. He illustrated his contention thus: "The fact that missionaries were sent out with the sanction of Rome no more proves the modern Papal claims to universal supremacy, than the fact of a bishop being now sent to the interior of Africa with the sanction of Canterbury would prove the universal supremacy of the Primate of England." I Dr Stokes, borrowing the idea, asks whether the fact of the first bishop in the United States having derived his orders from the Church of Scotland proves the supremacy of the Scottish bishops over the American Church. ${ }^{2}$ The reply is

1 Todd, "St Patrick," p. 333.

2 "Ireland and the Celtic Church," p 51. 
exceedingly simple. The parity is denied, until Dr Todd and Dr Stokes can produce an Archbishop of Canterbury or a Scottish Primus claiming and exercising universal jurisdiction, and having that claim recognised by the universal Church-in other words, until these gentlemen can tell us of a Protestant Pope enjoying the aforementioned privileges.

If the Church of St Patrick did not acknowledge Roman supremacy, then Celtic Christianity was an extraordinary production. At the time of St Patrick's mission, as we have seen, Britain acknowledged it. Gaul, Spain, Italy, and Africa did the same, and as yet the Greek schism from the Roman See had not taken place. As a matter of fact, the early Church of Ireland was in full communion with the rest of Christendom, as history records, and, therefore, must have accepted papal supremacy as part of the common faith. Had it been otherwise, the fact would have been as widely recorded as is the heresy of Pelagius.

But to return to the evidence that $\mathrm{St}$ Patrick received a commission from Rome to preach in Ireland. 
1. We have as a testimony the universal and ancient tradition that it was so. This tradition is embodied in documents dating from the seventh century onwards. It is well known that the Celtic mind is exceedingly tenacious of ancient tradition. Can it be possible, then, that the traditions of the sixth century were suddenly reversed during the seventh without a trace in history? It is futile to quote the influence of Pope Honorius in 629, for there is not the slightest shadow of evidence that the conciliatory procedure of that Pontiff gave rise to the theory of St Patrick's Roman mission. Besides which, the very fact that Honorius conciliated postulates that his authority was already accepted. To try to build up one argument from silence upon another of the same kind is absolutely worthless.

That the Catholic tradition was committed to writing in the seventh century is a positive fact, but that fact implies another-namely, that the tradition already existed. ${ }^{1}$ And to accuse the immediate disciples of St Patrick of fraud is both gratuitous and unreasonable.

1 Dr Whitley Stokes holds that these ancient documents "may embody early records" ("Tripartite Life of St Patrick," p. cxxix.). 
If documentary evidence of a positive tradition, dating from the seventh century, could be produced, denying papal supremacy and St Patrick's Roman mission, how eagerly non-Catholics would seize hold of such, and how triumphantly such evidence would be used as being absolutely conclusive! An appeal would be made, and rightly so, to the accuracy of Irish tradition and the tenacity of the Celt. But because the ancient documents before us bear witness to what are termed "papal pretentions," they are considered as practically valueless.

(2) One of the sayings of St Patrick"Dicta Patritii" - to be found in the Book of Armagh is deserving of special attention. Dr Whitley Stokes is of opinion that these sayings are really the Saint's own composition. ${ }^{1}$ Cardinal Moran thus translates the one with which we are concerned: "Thanks be to God; you have passed from the Kingdom of Satan to the city of God; the Church of the Irish is a Church of the Romans; as you are children of Christ, so be you children of Rome." 2

\footnotetext{
1 "Tripartite Life" (Rolls Series), p. cxxix.

2 " Early Irish Church," p. 23.
} 
Here we have a reference to the See of Peter as the source of the faith that had been delivered to the Irish, and an exhortation to remain ever true to the Roman Church-a maxim which has never been forgotten by St Patrick's children.

(3) In less than 100 years from the death of St Patrick, Columbanus, who had conversed with Patrick's own disciples, thus wrote to Pope Boniface IV. : "The Catholic Faith is held unshaken by us [Irish], just as it was delivered to us by you [the Popes], successors of the holy Apostles." 1

(4) St Ultan, who died A.D. 657, having attained a great age, wrote a Life of St Patrick, which has been lost. His disciple, St Tirechan, however, has, fortunately, preserved for us in the Book of Armagh some extracts of the lost volume. These thus attest the truth of the papal mission of St Patrick.

"The second Patrick" (Palladius is called Palladius Patrick) "was sent by the angel of God, Victor, and by Pope Celestine; all Ireland received his teaching, and nearly all of it was regenerated by him in baptism." 2

1 Epist. ad Bonif. Migne, P.L., vol. lxxx.

2 Whitley Stokes, "Tripartite," p. 332. 
(5) The Chronological Tract in the Lebar Breac (A.D. c. 832) says: "Palladius was sent by Pope Celestine with a Gospel for Patrick to preach it to the Irish. . . . In the year after this Patrick went to preach it in Ireland. It was in this year that Sixtus assumed the supremacy of Rome, after Celestine; and it was the fourth of the reign of Leoghaire, son of Niall, at Tara." 1

(6) The annals of Ulster, under the year 439, state "Secundinus, Auxilius, and Iserninus, being bishops, were sent into Ireland to the assistance of Patrick." And the same annals record, under the year 441, that when Patrick in the far West heard of the accession of Pope Leo the Great, the Saint sent Munis to Rome "with counsel for the coarb [abbot] of Rome," and relics were given him ; and his messenger brought back the blessing of the Pope on Patrick's work and the confirmation of his apostolate in Ireland. ${ }^{2}$

(7) St Eileran's Life of Patrick (A.D. 664) thus relates the mission from Pope Celestine : "St Germanus sent the blessed Patrick to Rome, that thus he might receive the sanction

1 Whitley Stokes, "Tripartite," p. 555.

2 Ibid. p. 85, etc. ; also Fr. Morris, "Life of St Patrick," p. 76 ; and Moran, "Early Irish Church," p. 26. 
of the bishop of the Apostolic See to go forth and preach, for order so requireth. ... And Patrick having come to Rome, was most honourably received by the holy Pope Celestine, and relics of saints being given to him, he was sent into Ireland by that Pontiff." 1

(8) Eric of Auxerre, a French monk of the ninth century, wrote a Life of St Germanus. Speaking incidentally of the Apostle of Ireland, the author says: "Germanus sent him [Patrick] to Pope Celestine, the Pope of the city of Rome, accompanied by his own priest Legetius, who might bear testimony to his ecclesiastical probity at the Apostolic See." This does not read as if it were fabrication; it is a simple statement from the pen of a stranger who is writing a genuine account of a Bishop of Auxerre. ${ }^{2}$

These ancient documents, although varying in many a detail, agree in assigning to St Patrick a mission from Rome, and no amount of negative argument can avail against such very positive evidence.

The opinion of the learned Archbishop Healy of Tuam cannot be lightly passed

' Colgan, "Tr. Thaumat," p. 39.

2 Article on "Early Irish Church," Irish Eccl. Record, March 1903. 
over. These are his words, spoken at the consecration of Armagh Cathedral in July 1904, before a vast multitude, including some of the most learned prelates of our times: " $\mathrm{He}$ [Patrick] had also the ordinary commission from the Pope, St Celestine. All the ancient Lives of the Saint assert it; all our native annalists assert it; the Book of Armagh, the official record of the Primatial See, asserts it ; the ablest Protestant writers, like Ussher, have admitted it. In fact, the 'Roman Mission' was never questioned until our own times, and then only for controversial purposes by certain scholars, who had nothing to rely on but a purely negative argument." 


\section{CHAPTER VIII}

THE IRISH CHURCH AND PAPAL SUPREMACY

IT has been clearly shown in the foregoing chapters that early Irish Christianity came from Rome, bearing upon it the seal of the authority of the Supreme Pontiff. Such being the case, there could not have been diversity of belief between the sender and the one sent.

Let us first of all quote the words of Pope Boniface I., Celestine's immediate predecessor. They are addressed to Rufus, a bishop, not of the Western, but of the Eastern Church. "On you, dearest brother," he said, "devolves the entire care of those [Illyrian] churches, which you will recognise to have been by us entrusted to you, as vicegerent of the Apostolic See." 1

And again: "It is certain, then, that this See [of Rome] stands in relation to the churches spread over the whole world as the head is to its own members, from which

${ }^{1}$ Bonif. Epist. v. Migne, P.L., xx. 762. 
Church whoso has cut himself off becomes an outcast from the Christian religion, since he has ceased to be in the bonds of fellowship." 1

Pope Celestine renewed Boniface's commission to Bishop Rufus, and at the same time wrote to the Bishop of Illyria regarding the legatine powers with which Bishop Rufus had been invested by the Pope: "Let none be ordained without counsel from him to whom you know our vicegerency has been committed throughout your province." 2

The words of the same Pope Celestine, already quoted, may be here repeated: "We are in a special manner constrained by our charge with regard to all men; we to whom, in the person of Peter, Christ has graciously imparted the necessity of being engaged about all when He gave the keys to open and shut." 3

St Leo I., who, according to the Annals of Ulster, confirmed the work of Patrick, asserts in an unfaltering tone that the See of Peter is "the first of all the Sees . . . the

1 Bonif. Epist. xiv. Rufo.

${ }^{2}$ S. Coelestini Epist. iii. ad Epis. Illyr.

Ibid. 
head . . . that See which the Lord appointed to preside over the rest." ${ }^{1}$ And in another letter he says: "Others [bishops] again, constituted in the greater cities, should undertake a wider care, through whom the care of the universal Church flow together to the one See of Peter, and no part be anywhere at variance with its head." 2

Now, it may be asked, did St Patrickthe one sent-hold identity of belief with his senders? We have ample indication that he did.

(1) We have his exhortation in the Book of Armagh : "Ut Christiani ita et Romani sitis"3_ "Let your Christianity and your fidelity to Rome be coextensive."

(2) We have the statute in the Book of Armagh, in that part, too, which purports to have been copied from the book written by St Patrick's own hand. It runs as follows :- "Moreover, if any case of extreme difficulty shall arise, and one which

1 Epist. cxx. C.I. ad Theoderet.

${ }^{2}$ Epist. xiv. ad Anastas. Thessal. Episc. c. 11. The belief of the churches of Gaul and the East at this time is sufficiently indicated in the writings of the Fathers, and the decrees of Councils collected by C. F. B. Allnatt in "Cathedra Petri."

3 Whitley Stokes, “Tripartite," p. 301. 
the various judges of the Irish nation cannot decide, let it be referred to the See of the chief bishop of the Irish [that is, of Patrick] and submitted to his episcopal examination.

"But if such a case of the aforesaid importance cannot easily be decided in that See with the assistance of its wise counsellors, we have decreed that it be sent to the Apostolic See-that is to say, to the Chair of the Apostle Peter, which holds the authority of the city of Rome.

"These are the persons who decreed as above-namely, Auxilius, Patrick, Secundinus, and Benignus." 1

These two latter bishops were St Patrick's closest friends and coadjutors.

In a collection of ancient Irish Canons, dating from about the year 700 , the same enactment appears thus: "St Patrick defines should any grave controversies arise in this island, they shall be referred to the Apostolic See." 2

It is natural to expect that such an important enactment as this should not be

'Translation from Cardinal Moran's "Early Irish Church," p. 121.

${ }^{2}$ Collect. Hib. Canouum, lib. xx. c. 5, vide Moran, p. 123. 
allowed to pass unchallenged. Haddan and Stubbs attempt to minimise its force by attributing it to a date after primacy had been established, or at least claimed, for Armagh.1 At most, however, this objection only touches the Canon in the form in which it stands in the Book of Armagh without affecting its substance.

Dr Todd ominously avoids the subject. Dr Whitley Stokes does not contest it. He says: "St Patrick had a reverent affection for the Church of Rome, and there is no ground for disbelieving his desire to obtain Roman authority for his mission, or for questioning the authenticity of his decrees, that difficult questions arising in Ireland should ultimately be referred to the Apostolic See." 2

It is not easy to understand how the genuineness of this Canon can be impugned. The present manuscript was transcribed in the year 807 , and at that time the original from which it was copied was believed to be in the actual handwriting of St Patrick. But perhaps the strongest testimony in its

${ }^{1}$ Councils, Vol. II. part ii. p. 332. Professor Bury shows that St Patrick laid the foundations of Armagh's pre-eminence, p. 15.

2 “"Tripartite Life," vol. i. p. cxxxv. 
favour was the practical use made of it in the Synod of Magh-lene in the year 630, when it was actually quoted and acted upon. These are St Cummian's own words : "In accordance with the synodical decree, that when causes were of great moment they should be referred to the head of cities, our seniors judged it proper to send wise and humble men to Rome, as children to their Mother."1

This decree of St Patrick was practically the promulgation of a Canon of the Church Universal, of which he was a dutiful son. The Council of Sardica, A.D. 347, in which British bishops took part, sanctioned appeals "from every province to the head-that is, to the See of the Apostle Peter." 2

(3) The final proof, however, of St Patrick's belief in papal supremacy is that which we do not find committed to writing in synodical decrees, but is inscribed "in the fleshy tablets of the heart." Like the faith of the Romans, of which St Paul speaks in his Epistle, and with which there is identity and continuity among the

1 Ussher, vol. iv. p. 442 ; also "Cathedra Petri," p. 93.

"Epist. ad Julium, vide "Cathedra Petri," p. 61. 
Irish, the faith of St Patrick's children "is spoken of in the whole world." ${ }^{1}$ The Christianity of the Irish from its very commencement has been pre-eminently Papal, because pre-eminently Catholic.

${ }^{1}$ Rom. i. 8. 


\section{CHAPTER IX}

APOSTOLATE OF ST KENTIGERN

Prior to the advent of St Columba to Caledonia, the work of evangelisation had been in active progress in the kingdom of Strathclyde. The leader in this work was Kentigern, or Mungo as he is often called. Kentigern established himself at Cathures, not far from a cemetery which St Ninian had blessed 100 years before. This spot was afterwards hallowed by the presence of $\mathrm{St}$ Columba, for here Kentigern and Columba met and exchanged staves: "For a pledge and token of their mutual love in Christ." ${ }^{1}$ In after years this sacred place became the famous Glasgow.

Whatever is known concerning St Kentigern comes to us from the pen of Abbot Jocelin of Furness, in the twelfth century. The materials which Jocelin had before him for his work date back, in all probability,

${ }^{1}$ Moran's "Irish Saints in Great Britain," p. 160. 
to the eighth century; such, at least, was the opinion of the late learned Marquis of Bute. $^{1}$

One of the chief episodes in Kentigern's life was his exile from Glasgow to Wales. There he became the associate and friend of St David the Bishop. During his many years of exile St Kentigern is said to have journeyed several times to Rome, out of devotion to the Apostolic See. Modern critics question the fact of the pilgrimagessome altogether denying them, on the plea that the story is an invention of the Middle Ages, when it became the fashion to attribute everything to Rome. It is not easy to understand why the possibility of visiting the Eternal City should be denied to St Kentigern; for as the late Marquis of Bute says: "That these Celtic bierarchs occasionally went to Rome there can be no doubt; see, for instance, St Wynnin, and many other instances, and the way Cummian speaks in his letter upon the wretched Paschal controversy. . . . However, Jocelin gives one fact: that on his return [from Rome], on the last occasion, Kentigern had

${ }^{1}$ Lecture delivered at Glasgow University in the year 1882. 
an illness so severe that he hardly got home at all." 1

When he made this last pilgrimage Kentigern is said to have met St Gregory the Great, who bestowed many gifts upon him.

St Kentigern's bell, which had been brought from Rome, was preserved in Scotland till after the Reformation, but cannot. now be traced. It still figures, however, in the arms of the city of Glasgow.

Professor Cooper, in a lecture delivered by him at Glasgow, November 1898, had the temerity to assert that "St Kentigern was never at Rome in his life." We may reasonably ask whence did the Professor derive this information. Abbot Jocelin, as we have seen, says distinctly that he did, and the Marquis of Bute thinks it possible. Abbot Jocelin, with his eighth-century materials before him, is more likely to be right than Professor Cooper, whose opinion decidedly savours of anti-Roman prejudice.

St Kentigern was consecrated bishop about the year 540. The ordination was

${ }^{1}$ Leeture, 1882 , p. 5. 
performed by a prelate of the Church founded by St Patrick, thus establishing a bond of union between the hierarchy of the Church in Strathclyde and that which had been initiated under Roman auspices in Ireland. As at this period the first order of Irish saints had not died out in Ireland, it may well have been that $\mathrm{St}$ Kentigern's consecrator was one of that goodly company which numbered in its ranks the holy bishops Ailbhe, Fedhlemidh, Lugadh, and Nathy. ${ }^{1}$

It has become a favourite theory among a certain class of modern non - Catholic writers to ascribe, gratuitously, the Roman missions and ordinations of the earlier Celtic bishops to the unscrupulous forgeries of the Middle Ages. Kentigern's biographer attests that the Saint's consecration took place in Strathclyde by an Irish bishop. When we consider the many journeys St Kentigern is recorded to have made to Rome, surely Jocelin and his predecessors have allowed a golden opportunity to pass, which could have been so easily utilised had forgery been so rife.

"Moran, "Irish Saints in Great Britain," p. 161. 


\section{CHAPTER X}

APOSTOLATE OF ST COLUMBA

Seldom has the belief of any saint been more seriously misrepresented than St Columba's. "He and his followers," says Dr Ledwich, "firmly opposed the errors and superstitions of the Church of Rome." 1 Writers later than Ledwich would probably hesitate to express themselves so boldly, yet Dr Lightfoot affirms that "Celtic Christianity grew up a strictly native growth." ${ }^{2}$ The Celts themselves never dreamed of such folly as to claim "native growth" for their Christianity; had they done so they would have proved that their Christianity was no Christianity at all.

Our Presbyterian friends can easily be imagined asking the question: "Do you really mean to tell us, then, that St Columba was a Roman Catholic? Why, we have been always told that he shaved his head differently

"Ledwich, "Antiquities of Iroland," as quoted by Smith, "Life of Columba," p. 12.

2 Lightfoot, "Leaders in the Northern Church," p. 7. 
from Roman monks, and that he kept Easter on a day which did not coincide with the feast at Rome, therefore he could never have been a Roman Catholic; indeed, not a few of us hold that in his heart he adhered to the opinion of our own beloved Knox."

Fortunately for our friends, we have not been left in ignorance concerning St Columba's "Roman " Catholicism, thanks to St Adamnan and other ecclesiastical writers of renown. Despite, therefore, the fact that Presbyterians and Anglicans occasionally venture to name their churches after the Apostle of Caledonia, we do not hesitate to affirm that St Columba had as little to do with Presbyterianism or Anglicanism as the present writer has to do with the administration of the Fiji Islands.

If it can be established from indisputable documentary authority that St Columba and his monks believed in papal supremacy, and a host of other doctrines which Protestants describe as "Roman Catholic," then it follows that they were "Roman" Catholics in the modern meaning of that term, and that if they were to revisit the scene of their earthly labours they would find themselves at home, not in the manses and kirks of Established, 
Free, or United Free, but in monasteries such as Fort Augustus, or in churches of which the priests are in communion with the See of Rome.

But what was St Columba's attitude towards the Holy See? In the absence of direct reference in the Life by Adamnan it may reasonably be inferred from the attitude of his ecclesiastical preceptors. While yet a cleric, Columba was under the tutelage of St Finnian of Moville. This St Finnian not only inherited the traditions of the Irish Church respecting papal authority as embodied in the famous Canon of Armagh, but he had frequented the schools of Candida Casa in Galloway, founded a century before by the papal missionary to Scotland - St Ninian.

While there, Finnian's desires went Romewards, so with wallet and staff he set forth on the journey. Having been received with honour by Pope Pelagius, he remained in the Eternal City for the space of three months, learning apostolical customs and ecclesiastical laws.

On returning to Ireland, Finnian carried with him a newly-corrected version of the 
Bible, the work of St Jerome under the immediate sanction of the Pope. Columba transcribed the Latin psalter from this Roman book, and the copy is still preserved in Dublin.1

It is worthy of note that St Columbanus, in his letter to St Gregory the Great, assumes that the Pope is familiar with the names of Gildas the Briton and Finnian of Moville. $^{2}$

There is every reason to believe that $\mathrm{St}$ Columba's fidelity to St Peter's Chair would equal that of his holy master, and that undoubtedly it was so evidence is not wanting. An ancient Irish Life, dating back to the beginning of the twelfth century, and quoted by Dr Skene, records a tradition that before St Columba passed over to Scotland he too desired to visit Rome, and having set out on his pilgrimage, arrived at Tours. For some reason unknown he proceeded no farther, but brought back to Ireland a copy of the Gospels that had rested for a century

'Montalembert, "Monks of the West," iii. 127. As to any dispute between Columba and Finnian, it is evident, says Lanigan (ii. p. 148) that it did not occur; and the two saints retained their mutual friendship till death (Adam. L. iii. c. 4. Fowler's ed.).

${ }^{2}$ Migne, P.L., vol. Ixxx. pp. 262, 263 ; also Dialog. S. Greg. iii. c.q. 
on the relics of St Martin. That book he left in Derry. ${ }^{1}$

During the later years of Columba's life, St Gregory the Great occupied St Peter's Chair, and in all probability there were communications between these two holy men. A venerable tradition informs us that on one occasion messengers came from Pope Gregory to Iona, bearing with them as gifts the Cross, known long afterwards as "the great gem of Columkille" (preserved till the sixteenth century), and also the Liber Antiphonarius; in gratitude for which presents Columba sent to Pope Gregory his famous composition commencing "Altus Prosator." 2

It seems almost incredible that traditions such as these should have originated as forgeries during later ages. The onus probandi lies on those who make these gratuitous assertions.

That communications with Rome were by no means improbable is clear from what Adamnan informs us concerning St Columba's vision of Citta Nuova, a city of the Roman province. The holy man saw in vision the 1 "Celtic Scotland," vol. ii. p. 483.

${ }^{2}$ Dr Reeves' “Vita St Columbe," p. 318; also Moran's “Irish Saints," p. 105. 
destruction of that place; and not long afterwards he and Lugbe, happening to be in Kintyre, a ship arrived from Gaul bringing the news that everything had happened according to the revelation made to the Saint. ${ }^{1}$

Then, again, we know from the testimony of Adamnan that the discipline at Iona was in perfect accord with the discipline of the Irish Church. At the time of St Columba, and for years afterwards, Iona drew almost all its subjects from Ireland. We may, therefore, with safety adduce the belief of $\mathrm{St}$ Columba, regarding the authority of the See of Rome, from the practice of the Irish Church at that time. In the third Canon of the Penitential of St Cummian ${ }^{2}$ it is laid down that if a monk should violate celibacy, and refuse to perform condign penance, "the Holy Synod, or the Apostolic See, is to separate him from the communion and intercourse of Catholics." Cummian, who formulated this Penitential, was not only a fellow - countryman, but a contemporary of St Columba. Now, if in so minute a circumstance as the excommunication of a refractory

1 Fowler's Adamn. L. i. c. 28.

2 Migne, P.L., lxxxvii. p. 985. 
Irish monk it was necessary for the Apostolic See to pass sentence, it can hardly be imagined "that papal jurisdiction was not exercised in more weighty matters.

But our Protestant friends will ask: "Did not Columba come to Scotland without any commission from the Pope, and thus display his independence of Roman jurisdiction?" Bede tells us that "he came to Britain for the purpose of preaching God's Word to the people of the provinces of the Northern Picts." 1 Adamnan says that he undertook the journey into Britain "for the love of Christ" - "pro Christo." 2 The motives which led him to Scotland were twofold-(1) the conversion of the Northern Picts ; (2) the instruction of his fellow-countrymen in the Dalriadan colony of Argyle and its adjacent isles. The Dalriadans were to Columba what the Jews of the dispersion were to the Apostle St Paul-his " kinsmen according to the flesh."

This migration to Caledonia by no means severed St Columba's connection with his native land; on the contrary, he revisited it more than once, and took a leading part in Irish affairs.

${ }^{1}$ Hist. Eccl. L. iii. c. 4.

${ }^{2}$ Præef. II. ad L. i. c. 1. 
The year of St Columba's arrival in Scotland was 563. The grant of Iona to the Saint and his companions was made by Conall, a kinsman of Columba, and King of Dalriada.

St Columba entered upon his Apostolate as a son of the Irish Cluurch, whose beginnings had been marked with papal approval. Whether the Saint obtained the sanction of Rome before setting out we do not know. Formal or explicit authorisation from the Pope, however, was not required in those times for such a work as Columba undertook. The Popes themselves had always enjoined on the bishops and clergy the positive duty of solicitude for the conversion of their heathen neighbours. The local ecclesiastical authorities, realising this obligation, were free to make their own plans without, however, seeking the direct intervention of the Holy See, though occasionally formal approbation was solicited and obtained.

That such was the case is evident from the Epistles of Pope Gregory the Great to the temporal rulers, through whose dominions St Augustine and his companions were about to pass on their way to preach to the AngloSaxons. Pope Gregory (Columba's contem- 
porary) complains to Queen Brunichilda that "the neighbouring bishops [of Britain] have neglected to show any pastoral solicitude towards the Angles," and therefore he is sending Augustine into the missionary field. ${ }^{1}$ The Pontiff uses almost identical words to Kings Theodoric and Theodebert. ${ }^{2}$

From these facts it is certain that in coming to Caledonia St Columba was displaying no independence of Rome, but, on the contrary, was carrying into effect the known wishes of the Roman Pontiff. He was fulfilling a plain duty, which the British clergy had wilfully neglected, towards their Anglo-Saxon neighbours.

In passing, it is interesting to note that St Columba had Saxon converts in his community at Iona. Two are mentioned by Adamnan-namely, Genereus and Pilu. ${ }^{3}$ These were not indebted for their faith to the Roman missionaries, who as yet had not arrived in Britain, nor evidently to the British. The Irish clergy and monks had clearly undertaken that duty as opportunity occurred, and for this they are often praised by the Venerable Bede. ${ }^{4}$

1 Haddan and Stubbs, vol, iii. p. 10.

${ }^{2}$ Ibid.

${ }^{3}$ Fowler's Adamnan, L. iii. c. 10 and c. 22.

- Lanigan, Eccl. Hist. ii. p. 174. 
If St Columba has not left us any writing by which to assure us of his fidelity to the See of Peter, he has been fortunate in having a contemporary and fellow-countryman who virtually did this for him. What St Columbanus says we shall presently read; suffice it to say here that he was brought up in those very monastic schools which St Columba had frequented in Ireland. His letters express belief in papal supremacy as strongly and as clearly as if they had been written by Cardinal Logue in the twentieth century.

Is it likely that St Columba would have repudiated the doctrine of St Columbanus? If of two of my friends, who are Catholics, one says nothing about his belief in papal supremacy, but the other says a great deal, it becomes the duty of the person who maintains they are in conflict to prove his assertion.

St Columba's Life by Adamnan can hardly be called a biography, except that it begins with his birth and ends with his death: it is concerned chiefly with visions and miracles. It certainly does not contain an exhaustive list of the doctrines accepted by the holy Abbot, any more than do the written Lives 
of more modern Catholic saints; but on this account has anyone the right to affirm that such omissions are equivalent to repudiation? Yet this is practically what so many writers say with regard to St Columba. ${ }^{1}$

In describing the departure of the Saint from this world, Adamnan testifies that the fame of his holy predecessor was spread far and wide; and he reckons it among the favours granted by God to Columba that, "though he lived in a small and remote island of the British sea, yet his name is honoured, not only throughout the whole of our Ireland and Britain, but even in Spain and Gaul, and the renown of his sanctity has also penetrated beyond the Alpine range into Italy-yea, even to the city of Rome itself, which is the head of all cities." 2

To St Columba's disciples the city of Rome was "the head of all cities," not

1 Ancient annalists have recorded every detail and circumstance of controversics affecting minor points of discipline--e.g. Easter and the tonsure. Can it be conceived they would have passed over in silence quostions involving fundamental principles, such as a rejection of papal authority?

2 There existed at this time a British oolony in Spain (Gallicia) governed by a Celtic bishop who was a suffragan of the Archbishop of Braga-a striking testimony of the unity of faith existing botween Celts and Spaniards-and it is probable that the know. ledge of St Columba reached Spain through this colony from Britain. (Haddan and Stubbs, ii. P.I. p. 99); Fowler's Adamn. L. iii. c. 23. 
because of its temporal glory, but because of its spiritual pre-eminence. Rome at that time was no longer the throne of the emperors; it had been sacked and laid desolate by invading hordes of barbarians. But St Columba's fellow - countryman, Columbanus, gives us the reason for its pre-eminence in the eyes of the Celtic monks of the sixth century: "Although Rome is great and renowned, through that Chair alone [St Peter's] is she looked on as great and illustrious among us." 1

The Church to which St Columba belonged was, according to Columbanus' own testimony, "closely bound" (devincti) "to St Peter's Chair." 2 Can this, it is asked, in the name of truth, be affirmed of any body of Christians at the present day, except of those who are known to the world as "Roman Catholics"? If not, then it follows that St Columbanus, St Columba, and the Church to which they belonged, were "Roman" Catholics; for we are "Roman" Catholic precisely because, like them, we are "closely bound" to Peter's chair.

${ }^{1}$ Migne, P.L., vol. lxxx. p. 279.

${ }^{2}$ Ibid. 


\section{CHAPTER XI}

ST COLUMBANUS AND THE POPE

In discussing the attitude of the early Scottish Church towards the See of Rome no one can ignore the Celtic monk St Columbanus. He was not only a namesake, but also a contemporary of St Columba, being born but twenty years after the latter.

No one doubts the identity of belief which existed between Ireland and Scotland during the sixth and seventh centuries. The closest union existed between the Christians of the two countries. Many monasteries in Ireland were actually subject to the jurisdiction of the Abbot of Hy. Therefore we may safely argue from the faith of Ireland to the faith of Scotland, and what was believed in the Church of the former would certainly form part of the belief of the latter.

From Columbanus we may infer much concerning Columba. We have his Rule, his Penitential, his Sermons, and five of his Epistles. Born A.D. 543-the same year that 
St Benedict died at Monte Cassino-he was trained in the monastic schools of Ireland. He became a monk at Bangor, and lived there for a considerable time under Abbot Comgall. He was a trained and elegant scholar, well fitted to labour for the conversion of the pagan Gauls. No actual mention is made of personal relations between Columbanus and Columba, but the intimate friendship that existed between Columba and Comgall, and which is chronicled by Adamnan, is sufficient guarantee as to their unity of belief.

Having settled in Gaul, A.D. 588, Columbanus soon found himself out of harmony with the local clergy in the date of celebrating the Easter festival. The cycle used by him had originally come from Rome, through St Patrick, and that was sufficient reason for Columbanus to complain. Whereupon he addressed letters to Popes Gregory and Boniface, begging for a decision in favour of the old Roman Pasch. To Pope Gregory he speaks with a strange combination of freedom and respect. He asks the Pope how, with all the light of his wisdom, he can reverence a "dark Pasch," but he begs 
the Pope to direct towards him the power of his authority. He apologises for writing with "more forwardness than humility," and says that "it is absurd that my western letters should trouble you, who lawfully sit in the Chair of Peter, the key-bearer [of the Kingdom of Heaven]." $\mathrm{He}$ regrets that ill health, etc., prevent him from coming to Rome, "to draw of the living waters of knowledge that flow from heaven...."1

This Epistle failed to reach the Pontiff, so he wrote to Pope Gregory's successor, begging for the sake of Christ and "the unity of their common faith (per unitatem fidei) to confirm, if it be not against the faith, the tradition of our Fathers, that by your decision we may observe in our wanderings such customs regarding the Pasch as we have received from our elders." 2 The Pope's answer has been lost, but it must have been unfavourable; and as there is no further reference to this subject it is practically certain that Columbanus conformed to the Pope's wish.

Dr Bright, in his Early English Church

1 Fpist. Columbani, Migne, P.L., Ixxx. p. 260.

2 Ibid. p. 269. 
History, ${ }^{1}$ says that the relation of the Celtic churches to Rome "was one of veneration without subjection, as is manifest from the language of such a typical Celtic saint as Columban." Dr Bright could not have made a more unfortunate statement. As a matter of fact, there may have been a lack of what looks like becoming veneration in the letter of Columbanus, but there was certainly no want, of subjection, for he refers the whole question to the Pope's judgment (judicium tuum). ${ }^{2}$

The last letter from Columbanus was written two years before his death. The purpose of the Saint in writing to Boniface was to rouse that Pontiff to action against certain heretics in North Italy who still defended the orthodoxy of the "Three Chapters" concerning the natures in Christ. This letter well illustrates the traditional attitude of the Celtic Churches towards the Holy See. The following extract is characteristic of the whole :-

"We Irish, dwelling at the far end of the

1 p. 95.

2 Mere custom Columbanus conld dispute with Celtic warmth and flow of words, but where faith is concerncd he has nothing more to say; then he is all submission to the decrees of Rome. 
earth, are all of us disciples of St Peter and St Paul, and of all the Apostles, receiving nothing save what is the angelic and apostolic tradition. None of us has been a heretic, none a Jew, none a schismatic; but the Faith, just as it was at first delivered to us by yourselves [the Popes], successors of the Apostles, is held by us unshaken. ... I strive to stir thee up as the Prince of Leaders, for unto thee belongeth the peril of the whole army of the Lord. . . . Fearing do I moan unto thee, who from among the princes art the only hope, having authority through the privileges of the Apostle Peter. . . . We are closely bound [or are entirely devoted todevincti] to the Chair of Peter, for although Rome is great and renowned, through that Chair alone is she looked on as great and illustrious among us. . . . On account of the two Apostles of Christ, you [the Pope] are almost celestial, and Rome is the head of the whole world, and of the churches." 1

1 Fpist. Columbani, Migne, P.L., Ixxx. p. 275. Regarding the words: "Save the singular prerogative of the place of the Tord's resurrection," in one respect the Church of .Jcrusalom cnjoyed a pre-eminence not granted to Rome, since it was tho scene of our Lord's rising from the dead; but this referenco is not concorned with ecclosiastical supcriority. Columbanus is clear on that point 
These words were written by St Columbanus not later than the end of the sixth century, and are an indisputable testimony of two facts :

1. That Ireland received its faith from the Roman Pontiffs.

2. That Columbanus had learned to believe in papal authority in his native land-in the monastic schools of St Columba-and that the supremacy received his full recognition.

The Roman Pontiffs had sometimes found it necessary to remind ambitious prelates that Rome's supremacy was in no way due to its political importance. But no such warning was necessary to the Celts; they were fully aware of the fact that, to Catholics, Rome was great, as St Columbanus has expressed it, "only on account of the Apostolic Chair."

It was zeal for orthodoxy that caused Columbanus to overstep the limits of discretion in his fifth Epistle to Pope Boniface, but he emphatically declares the Roman Pontiff to be the "teacher and ruler of the

for Rome; for it is well known that, previous to the Conncil of Nicea, the Bishop of Jerusalem was subject to the Metropolitan of Cæsarea, and after the Council he remained for a time subject to Antioch. The whole tone of the letter leaves no doubt on the main point of Roman supremacy. Cummian, appealing to the authority of the Apostolic churches, names Jerusalem after Rome. 
whole Christian Church." So impressed was he with this fact that he could not endure the shadow of anything that appeared to him to favour heretical teaching. ${ }^{1}$

The following are the terms used by Columbanus in addressing the Pope, culled from his letters:- "Lord and Father in Christ; . Chosen Watchman; Prelate most dear to all the Faithful; the most beautiful Head of all the Churches of the whole of Europe; Pastor of Pastors; the Highest; the First; the First Pastor, set higher than all mortals; raised near unto all the celestial beings; Prince of the Leaders; his Father; his immediate Patron; the Steersman; the Pilot of the Spiritual Ship." 2

It would be difficult for any modern "Ultramontane" to formulate higher superlatives in praise of the papal office, yet these are the titles given to the Pope by the fellow-countryman and contemporary of St Columba.

1 Article, "St Columba'si Monks and Rome," Rev. G. Phillips, Ushaw Mayazine, 1899 and 1900.

2 "Cathedra Petri," p. 106 ; wee also Bury's "St Patrick," p. 369 . 


\section{PART III}

\section{DOCTRINE AND DISCIPLINE}





\section{CHAPTER I}

\section{UNITY AND UNIFORMITY}

BEFORE entering upon the subject of the Paschal controversy it is necessary to draw the reader's attention to the vital distinction between unity and uniformity. Inability to distinguish between these two points has led to numerous mistakes. In their technical signification unity and uniformity are not synonymous, for the one can well exist where the other is absent.

Unity concerns revelation, and is one of the four visible marks belonging to the Church as expressed in the Nicene Creed. Our Lord prayed for it, and infallibly obtained it. ${ }^{1}$ In the Catholic Church there always has been, and always must be, complete and visible unity of faith. When a Catholic rejects a defined article of the faith he thereby ceases to be a member of the Church.

Uniformity is altogether a different matter ;

$$
1 \text { John xvii. } 20,21 .
$$


it concerns the non-essentials of religion; and on this point it may be safe to say that complete uniformity never has existed in the Church, and it is practically impossible that it should do so, even were it desirable.

Uniformity is said to concern discipline, as distinct from dogma; hence the variation in the rites of celebrating Mass, the use of Latin, the observance of festivals, and so forth-all which things being of ecclesiastical, and not of divine institution, admit of modification and change according to times and circumstances. The Catholic Church is exceedingly comprehensive regarding discipline, but absolutely inexorable on points of dogma. She could not be otherwise without ceasing to be a divine institution. In short, it is the old distinction between essentials and non-essentials. The Church could exist without Easter and without the tonsure, but according to the divine plan, as made known to us, the Church could not exist without a supreme visible head.

Uniformity in ecclesiastical arrangements has never existed in the Catholic Church. There are divergencies now as great as there were in the days of St Adamnan. 
True it is that ecclesiastical sanction for many observances has been obtained, but there was a time when this approbation was implied rather than expressed.

Whatever divergencies existed in the Celtic Church, they concerned discipline, and not dogma; uniformity, and not unity. Had they concerned unity, the names of Columba, Aidan, and Colman would not have found a place in the Calendar among the saints of God, but would have been ranked with Nestorius, Arius, and Luther. Those Celtic saints were neither heretic nor schismatic, nor were they reformers of a single article of belief; they were, on the contrary, holy men and true sons of the Church, worthy of the veneration of the faithful in all ages.

In proof of what has been said the reader has only to recall to mind the fact that $\mathrm{St}$ Augustine, fresh from the city of the Popes, begged the Celtic clergy of Britain to cooperate with him in the work of converting the Angles-an impossibility had they differed in matters of faith. St Wilfrid, too, in the presence of Pope Agatho and the Fathers of the Roman Council, subscribed to the true 
and Catholic Faith, "in the name of every northern part of Britain and Ireland, inhabited by the English and Britons, as also by the Scots and Picts." 1

1 Beda, L. v. c. 19. 


\section{CHAPTER II}

THE PASCHAL CONTROVERSY

IN order not to burden the reader with too many details, the substance of the Paschal computations may be stated thus:

1. At Rome the old and original computation occasionally led to an erroneous date; an alteration, therefore, became necessary. The first change took place A.D. 444, when Pope Leo adopted for that year the more correct Alexandrian rule. Leo's successor, Pope Hilary, introduced an improved computation by Victorious of Aquitaine, which continued till the more perfect system of Dionysius Exiguus (A.D. 527) was finally accepted in Rome, and afterwards throughout the Catholic world.

2. Gaul continued to use the computation of Victorious of Aquitaine, althougb Rome had adopted that of Dionysius. This state of things went on till as late as the time of St Columbanus. Consequently the Gauls 
who found fault with him were not themselves following Rome.

3. The computation observed in the Celtic Church was the old Roman one, introduced by St Patrick at the time of Pope Celestine. Rome, as we have seen, began shortly afterwards to amend the Paschal rule, while Ireland continued to follow the older canon. The Celts quoted the authority of St Anatolius, a bishop revered both in Rome and Alexandria, whose Paschal computation had been published throughout the West in a corrupt form. ${ }^{1}$

St Columbanus was in Gaul when he was brought face to face, for the first time, with the Paschal dispute. The question was not raised in Britain till the advent of $\mathrm{St}$ Augustine. Up to that time, apparently, the Celtic churches had not become aware of any change having been made on the part of Rome. This was due, probably, to the difficulty of communicating with the Continent, owing to the fact that the Saxons had made themselves masters of the eastern and southern coasts of Britain.

1 Moran, "Irish Saints in Great Britain," p. 274; seo also Bury, p. 371 . 
Pope Gregory, as Bede informs us, had invested Augustine with jurisdiction over all the bishops of Britain, "that the unlearned may be taught, the weak strengthened by persuasion, and the perverse corrected by authority." ${ }_{1}$ Now, one of the objects St Augustine had at heart was uniformity regarding the date of Easter; he, therefore, endeavoured to induce the Celts to abandon their old computation and adopt the more correct form of Dionysius Exiguus. It was no question of faith, for Rome herself had twice changed her mind on the subject. On matters of faith, it is clear from $B e d e{ }^{2}$ there was not the slightest divergence between Celt and Roman. Had it been otherwise, Augustine could never have besought the Britons to become his fellowlabourers in converting the Saxons. No allusion was ever made to difference of doctrine; and it is inexplicable, as Dr Döllinger expresses it, ${ }^{3}$ that subjects of minor importance should have been discussed by both parties, while the chief point of all remained unmentioned.

1 Bede, H.E., i. 2.

2 L. ii. c. 2.

3 " History of the Church," Period Second, p. 61. 
It has been reserved to modern times to discover that the Celts did not acknowledge Roman supremacy, and that it was this point (although omitted by Bede) that was the one subject of controversy between the Britons and St Augustine. In support of this, the supposed declaration of Abbot Dinoth is adduced. This document, however, has been declared spurious by the best authorities. ${ }^{1}$

It is obvious from the writings of Gildas (A.D. 547) that the Britons did acknowledge papal authority. At that time complaints were made of the British clergy, many of whom, unable to obtain lucrative benefices at home, went to Rome to urge their claims against their competitors, and returning to their native soil, "stretch out violently their hands upon Christ's most holy Sacrifices."' There existed, therefore, an authority external to Britain, in whom ecclesiastical jurisdiction resided. No bishop in the world, outside Britain, ever claimed jurisdiction over the British Church except one - the Pope, and his authority had been

${ }^{1}$ Döllinger, "History," ii. p. 62 ; Bright, "English Church History," p. 96.

${ }^{2}$ Haddan and Stubbs, vol. i. "Epist. Gildas." 
formally acknowledged by British bishops at Arles and Sardica more than 200 years before.

St Augustine's conference with the British Celts failed. The action of the British was that recommended by a hermit-namely, to submit to his demands if he rose from his seat, and to reject them if he did not. If the spiritual independence of their Church had been at stake, is it possible that they would have risked it on so uncertain a contingency as the rising up of the archbishop? On the contrary, it is clear that the opposition was based on a fear of surrendering themselves to one whom they unjustly regarded as a haughty-minded prelate. They knew that St Augustine claimed the rank of archbishop over the Anglo-Saxons; and they presumed that, if they consented to work under him for the conversion of their detested conquerors, they would but emphasise their equality with their conquerors, and so they refused to acknowledge him as their archbishop.

Dr Bright says : “Their reverence for Rome did not, in their view, commit them to obedience to its emissary. But it must 
have done so had it included a belief in papal supremacy." 1 This is a gratuitous assertion, and quod gratis affirmatur, gratis negatur. The true explanation is as Abbot Gasquet expresses it: "The general attitude of implacable hostility maintained by the Britons towards their Saxon conquerors." 2

Another fact also must not be overlooked. The British had an archbishop of their own at Caerleon, on Usk. It is not likely, therefore, that Augustine would compel them to regard him as their Metropolitan unless all the British bishops consented to this transfer of jurisdiction. Moreover, it does not appear that St Augustine insisted upon any such course of action. ${ }^{3}$ Needless to say, Dr Bright endeavours to discredit a Welsh archiepiscopate.

St Lawrence succeeded Augustine in the See of Canterbury. About the year 609 the new archbishop, conjointly with ' his fellow - bishops Mellitus and Justus, wrote a letter to their "most dear Lords and

"Bright, "Euglish Church History," p. 95.

2 Gasquot, "History of Catholic Church," p. 18.

Lanigan, ii. p. 381.

"Bright, "History of tho English Church," p. 97. 
Brothers, the Bishops and Abbots throughout all Scotia [Ireland]." ${ }^{1}$ Only part of the letter is given by Bede, but he tells us that the rest was an entreaty to unity of peace and conformity with the rest of the Church. ${ }^{2}$

How necessary this was is evidenced by the action of Bishop Dagan, who, having paid a visit to Canterbury, became so irritated with what passed in the discussion that he refused to eat with the bishops, or to take his repast in the same house with them. ${ }^{3}$ Yet this Bishop Dagan paid a visit to Rome to solicit Pope Gregory's approval for the monastic rule of St Moluoc of Lismore. $^{4}$

To suppose that Dagan had previously made up his mind to hold no communion with the Canterbury bishops is opposed to the very fact of his visit. If he not only shunned their society, but refused to communicate with them "in sacris," then he went further than the exigences of the discussion demanded, for not faith was

1 Bede, L. ii. c. 4.

${ }^{2}$ In speaking of the Paschal question Bede often uses the phrase "unitas Catholica."

${ }^{3}$ Bright, p. 111.

+ Moberly's edition of Bede, p. 97 ; Ussher, p. 476. 
concerned, but only a non-essential of ecclesiastical discipline. ${ }^{1}$

Lawrence and his suffragans addressed a second letter to the British bishops, in order to promote the "unitas Catholica" regarding the date of Easter, but it proved ineffectual.

At length, about the year 630, Pope Honorius, as head of the Church, wrote an Epistle to the Irish bishops, exhorting them (not commanding, let it be noted) to adopt the new Paschal computation, and so conform in this matter of Easter to the synodical decrees of the universal Episcopate.

Active measures were at once taken in order to give effect to the papal letter. The South Ireland bishops and abbots assembled in council at Old Leighlin, and declared that they had been instructed by their ancestors to respectfully follow the practices of the successors of the Apostles, and therefore they resolved to keep Easter with the Universal Church. Shortly afterwards a troublesome person (Cummian calls him "a white-washed wall") arose, and initiated 
a strong opposition to this action of the synod. To put an end to the disturbance it was resolved to refer the whole matter to Rome, according to the synodical decree of St Patrick that important matters should be carried to Rome, the head of all cities. To Rome, accordingly, deputies were sent, "as children to their mother," to learn wisdom.

This action of the bishops and abbots of South Ireland was not so much an appeal to the judgment of the Holy See as a resolution to be guided by the practice of Rome.

After about three years the deputies returned, bringing the news that the Irish usage was not in accordance with that of Rome. Thenceforward, from the year 633, the reformed Roman computation was adopted, and thus the controversy was for ever closed as far as the southern part of Ireland was concerned - all of which was due to the exhortations of the Roman Pontiff. 1

The Paschal question proves beyond all doubt that the Celtic Church recognised papal authority. But it does more than 
this, it discloses the fact that this belief dates back to the time when Christianity was preached by St Patrick. The Fathers of Old Leighlin did not introduce anything new when they appealed to Rome, but, as we learn from St Cummian, they merely acted on the ancient synodical decree. It has already been shown that this decree emanated from St Patrick. On his part too it embodies no new doctrine, but simply states the teaching he had imbibed in the schools of Gaul-from St Martin, and from the lips of St Germanus, the papal legate. ${ }^{1}$

${ }^{1}$ Healy, "Ireland's Ancient Schools and Scholars," p. 237. 


\section{CHAPTER III}

\section{ST CUMMIAN'S PASCHAL EPISTLE}

At this same time Cummian wrote his famous Paschal Epistle. It is addressed to Abbot Segenus and his community at Iona, whose acknowledgment of papal authority is taken for granted throughout the whole of this interesting document.

Cummian at this period was in all probability a monastic superior in South Ireland, and, in his capacity of a Columban monk, subject to Iona. ${ }^{1} \quad$ Abbot Segenus was St Columba's fourth successor, and ruled the community from 623 till 652 ; consequently he was the monastic superior of St Aidan, who entered on his mission in Northumbria A.D. 635.

The Epistle was intended to explain to the Abbot Cummian's action in discarding the old Paschal computation. He says that this was not due to contempt for his ecclesiastical superiors, but because the older

1 This Cummian is not Albus, but Fada, or " the Tall," 183 
reckoning caused him to be out of harmony with the whole Church. Before conforming to the new Paschal cycle Cummian says he had carefully studied Holy Scripture, the writings of the Fathers, and the decrees of Councils. On the Roman aspect of the question he makes use of the very words of St Jerome: "It must not be thought that the Church of the city of Rome is other than that of the whole world. . . Whoever is in agreement with the Chair of Peter, he is the authority to me." 1 The decrees of the Councils of Arles and Nicæa had greatly impressed him, for they had declared violators worthy of excommunication. But to say, as Professor Zimmer does, that Pope Honorius inflicted excommunication on the Irish is utterly false. ${ }^{2}$

Iona was not induced to imitate the example of St Cummian just then. It is well known how tenacious some persons are of customs that are ancient. The difficulty of bringing about the adoption of the Gregorian Calendar in Great Britain is well

${ }^{1}$ Migne, P.L., lxxxvii. p.969.

2 Zimmer, "Celtic Cluurch," p. 77; vide article by Rev. Dr MacCarthy, "Professor Zimmer on Early Irish Church," Irish Eccl. Record, November 1903. 
remembered. Scotland accepted it in 1600 , but England held out till 1751. The cry of the people: "Give us back our eleven days," is a fact of history. Russia to this day still clings to the Calendar unreformed. Old Christmas Day still survives in many parts of our country; and year by year in certain districts of Ross-shire the Highlanders tenaciously celebrate "Old New Year's Day." So hard do some traditions die even in an age of railways, electricity, and wireless telegraphy.

Had Iona or Ireland been independent of Rome how different would have been their attitude during the Paschal controversy! They would have indignantly replied: "We have nothing to do with Rome or its Bishop; we do not know of any obligation to submit ourselves to papal authority." But words like these were never said. Indeed, at Whitby, as will presently be shown, the Celtic monks upheld the fact of the divine institution of the Primacy. Cummian, in his letter to the Columban community, quotes the practice of Rome as the pattern to be followed by all; and he refers to the synodical 
decree of the Irish, that matters of importance are to be sent to Rome for settlement. The tone of the whole Epistle assumes that the belief of the Iona community on the question of papal authority was identical with his own. And although Iona was slow, and even obstinate, to adopt the improved computation, nevertheless it did accept it in the long run; and it did so without introducing any new theory about spiritual jurisdiction, because papal authority had been acknowledged in Ireland from the days of St Patrick, and had been taught in Iona by St Columba, its founder.

Therefore Cummian, when writing from his Irish monastery to his abbot and fellowmonks across the sea, not only informs them of the delegates recently despatched to Rome, "as children to their mother," but he reminds them too of the solemn sanction of St Patrick, and the other bishops with him, that important questions should be referred to the Apostolic Chair of Peter, thereby indicating that this important principle was as well known and acknowledged at Iona as it was in Hibernia. Let it be repeated again, belief in papal 
supremacy was no subsequent addition to the creed in Iona; St Columba had already brought it thither from the Church of St Patrick, together with the Mass, Confession, Purgatory, and a host of other "Roman" Catholic doctrines. It was not, as the Anglican Canon Cowley Brown (of Edinburgh) so playfully endeavoured to express it, that "the Roman egg was laid long afterwards in the nest of another bird." 1 St Adamnan was no ecclesiastical cuckoo; he strove to win over the monks to the observance of an emendated Calendar, but not to the acceptance of Roman authority, which was already believed by them.

Pope Honorius, as has already been stated, admonished the Celts of southern Ireland; but that does but prove the acknowledgment of his authority. Pope Pius X. is not likely to admonish either the members of the General Assemblies in Scotland or the Houses of Convocation in England on their differences in doctrine, much less their non-observance of Holy-days of Obligation, and why?-for the simple reason that

1 Vide art. of Rev. G. Phillips, "St Columba's Monks and Rome," in Ushaw Magazine, 1899. 
the Protestant bodies of both countries are not in papal communion. The Celtic Christians received papal admonition because they regarded the Roman Pontiff as their legitimate and divinely appointed ecclesiastical superior.

But our separated brethren reply: "The monks of Iona did not obey." Granted that they did not, does that fact involve a rejection of papal authority? A son may fail to promptly obey his father's behests, but that does not imply absence of belief in the father's right to command. The attempt to introduce a reform is invariably attended with opposition, but thereby to conclude that the authority which enforces a change is disowned is unreasonable and absurd, even should the resistance in itself be indefensible and wrong.

It must be borne in mind, when discussing the attitude of the monks of Iona towards the Easter question, that they were being called upon to surrender an immemorial tradition, sanctified not only by St Patrick, their Apostle, but also by St Columba, their holy founder. ${ }^{1}$

'Vido Ushaio Magazine, 1899 and 1900, Rev. G. Phillips' articlen on "St Columba's Monks and Rome." 


\section{CHAPTER IV}

THE CONTROVERSY IN NORTH IRELAND AND IONA

Notwithstanding opposition, St Cummian's Epistle was productive of some fruit. This is evident from the turn events took shortly afterwards in the north of Ireland, where the influence of Iona was paramount. Discussions arose, and the northern prelates deemed it advisable to act according to St Patrick's Canon, and consult the Apostolic See. The bishops and abbots drew up their letter and collected their documents, and forwarded everything to Pope Severinus. In the meanwhile the Pontiff died. John IV., the Popeelect, and certain of the Roman curia, read the letters, and formulated an answer, A.D. 640 - for let it be remembered the Pope-elect possessed full jurisdiction over the whole Church.

The prelates to whom the papal answer is directed are mentioned by Bede: "To our dearly beloved and most holy Tomianus, Columbanus, Cronan, Dima, and Baithan, I89 
bishops ; Cronan, Ernian, Laistran, Scellan, and Segenus, priests; Saran and the other Irish doctors and abbots." ${ }^{1}$ These prelates had spontaneously applied to the Pope for advice and instruction, not only on the Easter question, but regarding Pelagianism also-a most significant action to take. We possess a part only of the reply, and from it we learn that Rome entertained false impressions regarding the Celtic computation. It was thought that some persons in the province were tainted with the heresy of the Quartodecimans, which was not the fact, for the Celts never kept Easter except on a Sunday ; hence the unfounded suggestion in the letter of the Roman Clergy. ${ }^{2}$

This misunderstanding, coupled with the Iona influence in northern Ireland, apparently prevented the immediate adoption of the new computation. $^{3}$

Dr Bright fails to understand the true significance of this delay, and therefore says "that the majority paid more regard to the authority of the Columban monastery of $\mathrm{Hy}$

\footnotetext{
${ }^{1}$ Bede, L. ii. c. 19.

${ }^{2}$ Lanigan, ii. p. 384.

${ }^{3}$ Ilid. ii. 416.
} 
than to that of Rome itself, and retained their own 'Pasch' until 704, while Hy stood out until 716." 1 As a matter of fact, the action of the northern prelates evidences three points:

(1) The prelates referring the matter to Rome establishes a proof of intercommunion between Ireland and Rome, and through Ireland between the Columban community and Rome.

(2) It, moreover, indicates a recognition of papal authority.

(3) Still more, it is a plain recognition of papal authority, in spite of very strong national feelings in favour of ancient usage. And the wilfulness of those who clung to the unreformed Easter only proves their inveterate obstinacy. ${ }^{2}$

Before leaving this subject attention may be turned to Segenus, the abbot. His name is to be found among the list of the abbots who communicated with Rome on this occasion. In all probability he was the friend of St Cummian, and the then Superior of the monks of Iona. ${ }^{3}$ Here, then, we have this

1 Bright's " English Church History," p. 112.

"Phillips' "St Columba's Monks," Ushaw Magazine, 1899 and 1900.

Moberly's Bede, p. 134. 
reputed Celtic Pope of Iona, St Aidan's monastic superior, a humble suppliant at the feet of the Roman Pontiff-a singular indication of Columban independence ! ${ }^{1}$

${ }^{1}$ Lanigan suggested two substitutes for Segenus of Iona; but they are improbable, for (1) the names in Bede are in alphabetical order ; (2) the letter of Cummian could not have been ignored. 


\section{CHAPTER V}

\section{ST AIDAN IN NORTHUMBRIA}

THE church established in Northumbria by the Roman monk Paulinus suffered a rude shock in 633 through the defeat and death of King Edwin. St Paulinus retired permanently to the south, and but few clergy were left to carry on the work he had initiated. As soon, however, as St Oswald became King he took steps to propagate the faith that had been injured but not destroyed.

Oswald had been previously for several years an exile among the Scots, during which time he had received baptism at the hands of the Celtic monks. To these he turned for help, not to found a new faith, but " to extend the Church of Christ," as Bede expresses it. The work of the monks was to be a continuation of that begun by the Italian missionary Paulinus. ${ }^{1}$ From Iona a bishop was despatched; but his work failed, and he returned to his community at $\mathrm{Hy}$. Then Aidan was

${ }^{1}$ Bede, L. ii. 3. 
selected, and, having received episcopal ordination in his island monastery, he set out for his work at Lindisfarne.

Dr Bright does not allow to pass the opportunity of "not from Rome." He says : "He [Aidan] was sent from the Scottish Church at the request of a Northumbrian king; he would never have admitted the principle that all episcopal jurisdiction must be derived from Rome, or that a Pope had a right to make an English archbishop supreme over all the bishops of Britain. Yet Rome acknowledges him as a canonised saint." 1 Yes, Dr Bright; because Rome is the best judge of those who are her own spiritual children. Had St Aidan entertained the tenets Dr Bright gratuitously attributes to him, he certainly would not have found a place in the Calendar of the Catholic Church. The faith of St Aidan regarding papal jurisdiction was the faith of St Augustine's band of Italian missionaries, otherwise how could the latter have joyfully co-operated in Aidan's work?

With a spitefulness which is positively childish, Dr Lightfoot and other modern

1 Bright, "Early English Church History," p. 159. 
Anglicans never lose an opportunity of extolling the work of the Celtic missionaries to the disparagement of the efforts of St Augustine and St Paulinus, direct emissaries of the Pope. ${ }^{1}$ Their object is patent: they desire to find a precedent for their own rejection of papal authority, and so fasten on points like St Aidan's coming from Ionaand not direct from Rome-as an attempt to justify their own anti-papal position.

Let it be once more asserted that the Popes of those days, as is clear from the words of St Gregory, ${ }^{2}$ considered it a solemn duty incumbent on all bishops and clergy to make efforts for the conversion of their heathen neighbours. Therefore St Aidan, in acceding to King Oswald's request to work in Northumbria, was but carrying out a known duty and a papal commission, though indirect.

During St Aidan's episcopate Honorius, one of St Augustine's companions, occupied the See of Canterbury, and we are told that complete harmony existed between the two prelates. The Roman missionaries worked

1 Lightfoot, "Leaders of the Northern Church," p. 8.

${ }^{2}$ Haddan and Stubbs, vol. ii. p. 10 
in peace side by side with the zealous Celtic monks. Plain facts show that they did not form rival "communions"; but both bodies of men were animated by the one desire to extend the one faith of the one Church of Christ, of which the Pope was the visible head.

Even those who disliked the old Celtic custom of the unreformed Easter, observed by St Aidan, held the Saint himself in highest esteem, and even veneration. And among those who thus regarded him Bede makes special mention of St Honorius of Canterbury and St Felix, the Apostle of East Anglia. ${ }^{1}$ Had St Aidan's attitude towards the Pope been that ascribed to him by Dr Bright and other Protestants, instead of being loved as a brother by the Roman and papal Honorius he would have been shunned as a heretic and a schismatical intruder.

1 Bede, iii. c. 27. 


\section{CHAPTER VI}

THE WHITBY CONFERENCE

ST Finan, another Columban monk from $\mathrm{Hy}$, succeeded St Aidan at Lindisfarne in the year 651. During his episcopate Wilfrid entered Lindisfarne monastery, and became a subject of St Finan. With the frank consent of this bishop and his monks Wilfrid set out to visit Rome, in order to obtain the Pope's blessing on the studies he was about to commence. This speaks well for St Finan's recognition of papal authority, which, according to Dr Bright and his friends, was conspicuously absent in Celtic monasteries. Wilfrid not only went to Rome, but remained for some time with a bishop in Gaul-thus demonstrating identity of faith between the Celtic community of Lindisfarne (of which he was a member) and the churches in Gaul, and even of Rome itself. ${ }^{1}$

About this time an Irish priest named Ronan, who had learned the new Paschal

${ }^{1}$ Bright's History, p. 216. 
computation either in Gaul or Italy, began in the north to draw attention to the defective old Paschal cycle, and strove to win over the Celts to his side. His efforts with Finan were of a violent nature, resulting, as is usual with such methods, in bitterness and opposition.

The controversy issued in the Whitby Conference, A.D. 664. Matters were brought to an acute stage by the inconvenience caused in having two Easters celebrated in the royal household - the King observing the old style, and the Queen the new.

Meanwhile, St Finan died, and Colman, another Columban monk, succeeded to the bishopric. King Oswy now requested that a conference should be held, in which the disputed topic should be discussed from opposite standpoints. Bishop Colman and a few Celtic monks stood alone to defend the faulty computation. On the other side was the priest Wilfrid and the favourers of his cause. These latter, apparently, were more Roman than the Romans themselves, even to the fashion of shaving the hair. ${ }^{1}$ St Gregory, on the contrary, had insisted on no such ${ }^{1}$ Döllinger, "History of Church," p. 66. 
rigid uniformity, as may be gathered from his letter to St Augustine.'

King Oswy opened the proceedings, and called on St Colman to explain the old observance. This he did with calmness and dignity, appealing to the tradition of his holy predecessors and the authority of St John. St Wilfrid replied that the Roman computation had been introduced by St Peter, and had never been changed. If Colman was mistaken about St Joln, Wilfrid was certainly wrong regarding St Peter. But the true cause of the attachment of the Irish to their custom was disclosed when Colman appealed to the sanctity and miracles of St Columba and his holy successors.

Wilfrid replied that these saintly men were ignorant of the true Paschal canon, and would, doubtless, have followed it had it been presented to them. "But you are at fault," he said, "if with your knowledge you despise it."

Thereupon Wilfrid produced a deep impression on the assembly when to St Columba's authority, to which Colman had appealed, he opposed that of St Peter, Prince of the Apostles. The divine promises to

${ }^{1}$ Beda, i. 27, inter. 2. 
Peter were recited, after which the King questioned Bishop Colman, and the latter candidly acknowledged that to Peter, and not to Columba, had the supreme authority been given by Christ our Lord. Oswy then declared in favour of the new Roman Easter.

St Colman, although silenced by the argument of the King, did not relinquish the unreformed computation, but to remove every danger of dissension resigned his See, and returned with his Celtic and Saxon monks to Iona, and subsequently to Ireland, " to consult with his people what was to be done in this case." 1

Non - Catholics magnify this conduct of St Colman into disobedience to Rome. But as papal authority on this question had never been exercised towards the bishop, it is difficult to understand how he had disobeyed it. Neither Easter nor the tonsure belong to the essence of Roman faith or jurisdiction, and the dissent of the Celts never went further than these two usages. Their rejection of papal supremacy is either proven or not proven; if proven, where is the proof? The Whitby Conference was convened by the 
civil power; Wilfrid was but a priest at the time; he had not been delegated by the Pope to speak or act in his name; and the decision of the King was but a secular enactment. Both parties equally admitted the divine institution of the Primacy. Colman was a holy bishop, and is venerated as a Catholic saint, but he considered it his duty to defend the tradition of his Fathers until such time as the Roman Pontiff should exercise his supreme jurisdiction, and forbid the ancient usage. St Colman died in Ireland A.D. 676. 


\section{CHAPTER VII}

\section{ST ADAMNAN}

Adamnan, even before his election to the abbacy of Iona in 679, had adopted the new Easter and the coronal tonsure. Evidently, then, he was not regarded as either heretic or schismatic by his brethren. As their lawful superior he endeavoured to induce the monks to follow his example, but without effect.

In 703 he visited North Ireland, and while there was instrumental in causing almost all the Columban monasteries to accept the reformed Easter. St Adamnan died in his monastery of Iona A.D. 704. That, however, which Adamnan failed to accomplish was finally effected by the priest Egbert, an AngloSaxon. After remaining for several years in Ireland St Egbert passed over into Scotland, and proceeded to the abbey of Iona, where in 716 he ultimately succeeded in leading the monks to follow the new Easter computation and to adopt the coronal tonsure. Thus 
ended the prolonged controversy concerning the celebration of the principal Christian solemnity. ${ }^{1}$

As to the attitude of the early Scottish Church towards the Paschal question, it may seem to some that the monks were not free from blame, because of their persistency, but the fact that excused them most was their extreme veneration for the memory of St Columba. On the other hand, it is a little surprising that men such as Bede and Wilfrid should have considered the question as one of almost vital importance. It was a dispute which rested on astronomical calculations, not altogether dissimilar to that which raged round the new style called "Gregorian" during the eighteenth century. So long as the old style was in vogue in these kingdoms Catholics were at liberty to keep Easter on a date differing from Rome and many other places. Had the celebration involved a question either of dogma or of morals no Pope would have tolerated the divergence for a single day. ${ }^{2}$

1 Beda, v. 22. As to the alleged expulsion of monks from Pictland by King Nectan for nonconformity, the reader is directed to Lanigan, iii. p. 157.

2 Lanigan, iii. p. 67. 
The following quotation from Dr Döllinger is very apposite :- " It is impossible not to have remarked in the history of this dispute how greatly the importance of their differences was exaggerated by both partjes, and how unjust were the consequences which they deduced from the practice of each other. The Roman See displayed throughout that prudent wisdom and liberality which is peculiar to itself: so far was it from considering the attachment of the Irish to their own cycle as anything schismatical or heretical that it placed in its martyrology, and honoured as saints, two ecclesiastics - Columbanus of Luxeuil, and Aidan-who were among the most zealous defenders of the usages of their country.

"But Wilfrid, and even Bede, viewed this question, as a subject of great, almost of dogmatical, importance. The former estimated the bishops of the opposite party as no better than the Quartodecimans, as schismatical, and out of the communion of the Church; nor would he receive the episcopal consecration from them, or from those who had been consecrated by them. And yet so convinced was he of the orthodox faith of 
all the British, Irish, and Pict churches that when at Rome he bore solemn testimony to the same before a synod of 125 bishops." 1 And this at the very time (A.D. 679) when Abbot Adamnan was striving to win Iona to Roman usages.

Let the writers who so gratuitously accuse the Celts of ecclesiastical independence produce, if they can, one piece of contemporary evidence as clear as this to show that the Columban monks repudiated the jurisdiction of Rome.

The Celts were entirely innocent of the sin of schism. To constitute this sin there must be a formal renunciation of the authority of the Catholic Church and a formal renunciation of Church communion, or something equivalent. The very contrary was the practice of the Scottish Church. It not only never rejected the Pope's authority, but it was the custom of the Celts from the time of St Patrick to refer all the more serious matters to the Chair of Peter.

${ }^{1}$ Beda, v. 20; and Döllinger, ii. p. 70. It is childish to object, as some have done, that St Wilfrid had no mandate so to act. The circumstantial evidence is sufficient proof of St Wilfrid's veracity. There was no outery on the part of the Celtic Church; on the contrary, the Roman customs were ultimately adopted. 


\section{CHAPTER VIII}

THE TONSURE

At the close of the Whitby Conference Bede intimates that "there was no small debate on the question of the tonsure." 1

It was "the custom in Rome during the fifth century to shave the upper part of the head, and to leave around the lower part a circle of hair in the form of a crown. The Celts, on the contrary, shaved only the front of the head in the shape of a semicircle, allowing the hair on the back of the head to remain.

The Romans, apparently, thought little about the practice, for it is not so much as mentioned in any of the admonitions sent from the Apostolic See or in the complaints of the missionaries at this time. St Wilfrid and his followers maintained that the Roman form of the tonsure was instituted by $\mathrm{St}$ Peter, whereas that of the Celts originated with Simon Magus.

${ }^{1}$ Beda, iii. 26. 
As far as we know, neither St Peter nor Simon Magus wore tonsures of any kind, and it is difficult to determine what could have given rise to such strange ideas. In all probability the Celtic tonsure was introduced by St Patrick, who had become acquainted with it on the Continent; for St Paulinus of Nola (A.D. 420) speaks of certain monks whom he had met half tonsured, the fore parts of their heads only being shaven. ${ }^{1}$ If this be so, one can understand the reason why the Irish were so strongly attached to their particular form.

But on this point also the Celts at length yielded; and it is clear that the imaginary descent from the heretical Simon played no little part in bringing about the adoption of the Roman form.

It is obvious that the wearing of a tonsure formed no essential part of ecclesiastical discipline, much less of faith, for never once did any Pope insist on its adoption. Even now, of the tonsure there is a variety of form; and in some countries, notably in our own, the tonsure with the clergy is conspic-

1 Lanigan, iii. p. 68. Professor Bury (p. 243) discusses the fact that St Patrick ordered a Roman tonsure. After his death the native one was resumed. 
uous by its absence. In the United States of America ecclesiastical rule actually prohibits both secular and regular clergy from wearing any tonsure at all.

It is an instructive moral, that men should have striven for over 100 years about such points as the date of Easter and the form of the tonsure, and yet not detect the slightest doctrinal difference between themselves. Yet such was the case with Celt and Roman. 


\section{CHAPTER IX}

THE PRESBYTER-ABBOT

Anti-sacerdotal and anti-episcopal writers say that, because the presbyter (or priest) abbot of Iona had a bishop, or bishops, under him, therefore the abbot of Iona had no Roman Pontiff over himself.

These are Bede's own words on this subject: "That island $[\mathrm{Hy}]$ has for its ruler an abbot, who is a priest, to whose direction all the province, and even the bishops, contrary to the usual method, are subject, according to the example of their first teacher, who was not a bishop, but a priest and a monk." 1

That this abnormal arrangement indicates independence of Rome can be met with an unqualified denial.

Relative to this matter, let it be noted(1) that territorial dioceses had not at that time any existence in Scotland. Bishops travelled from place to place, and exercised

${ }^{1}$ Beda, iii. 4.

o 209 
their office as need required; (2) that at Iona, as everywhere else in Christendom, the episcopal order differed from, and was recognised as higher than, the priesthood. This is fully borne out by St Columba's own acts. In Adamnan's Life we are told that an Irish bishop named Cronan came to Iona humbly disguised as a priest. On Sunday morning, according to custom, Mass was celebrated, and St Columba invited the stranger priest to join him at the altar in the holy rite. But when the Mass was about to begin Columba, regarding attentively the face of the stranger, discovered he was a bishop. He then addressed him thus : "Christ bless thee, brother; do thou break the bread alone, according to the episcopal rite, for I know now thou art a bishop. Why hast thou disguised thyself so long, and prevented our giving thee the honour which is thy due?"1

The sacrament of Holy Order and the exercise of jurisdiction are two separate things. The power of Order and the power of jurisdiction (i.e. the right to rule the faithful) do not necessarily accompany one another.

'Fowler's Adamnan, L. i. c. 44. 
The power conferred in Holy Orders is incapable of modification, as it is a divine institution. No authority on earth can add to or take from its inherent powers; for instance, not even the Pope can empower a simple priest to ordain another priest or consecrate a bishop. With jurisdiction it is otherwise-that can be limited or extended or taken away, as circumstances demand. A priest, for example, may receive the order of bishop without receiving an atom of jurisdiction. Cases of this kind abound at the present day in the Roman Curia, where numbers of officials are bishops and archbishops, but without a particle of jurisdiction.

On the other hand, a cleric who is neither bishop nor priest can be invested with full episcopal jurisdiction. Thus if a subdeacon be elected to a vacant See, and regularly confirmed therein, from that moment he becomes possessed of all the jurisdiction pertaining to the said See; and, should it be a metropolitical one, the suffragan bishops are subject to him before he is actually consecrated.

Again, at the present time, in the Order of St Benedict, there are "presbyter-abbots" ruling dioceses with episcopal jurisdiction, 
having no immediate superior other than the Pope. Such are the abbots of Monte Cassino (formerly with four dioceses attached, making thus a quasi-province), Subiaco, La Cava, Monte Vergine (Italy), Martinsburg (Hungary), and New Nursia (Australia). Instances like these were probably unknown in Bede's time, hence his remark concerning the presbyterabbot of Iona.

However this may be, the arrangements in St Benedict's rule, with which Bede was familiar, illustrate the very same principle. In the sixtieth chapter regulations are laid down for priests who happen to be the subjects of an abbot not invested with any clerical dignity. St Benedict accords full jurisdiction to the abbot over such priests; but, if the abbot permit, the priest is " allowed to stand next the abbot, to give the blessing, and to say Mass."

It should not be difficult to understand how the abbot of Iona, as successor of St Columba, was permitted to retain superiority of jurisdiction over the monastic bishops serving the province, which originally had been won to the faith through the instrumentality of the Saint. 
This peculiar privilege of the abbot did not in any wise affect the essential distinction between bishop and priest, for we are informed by Adamnan that the Irish monks sent specially for a bishop to ordain $\mathbb{A d h}$ to the priesthood. ${ }^{1}$

Let it be noted also that the privilege was understood as belonging particularly to Iona ; for when the Columban monk St Aidan left the province of Iona he at once conformed to the normal arrangement of Church government. These are Bede's own words: "At Lindisfarne, from ancient times, the bishop was wont to reside with his clergy, and the abbot with his monks, who were likewise under the care of the bishop, because Aidan, who was first bishop of that place, being himself a monk, brought monks thither, and settled the monastic institution there, as the blessed Father Augustine is known to have done before in Kent." ${ }^{2}$ An unintentional testimony from the pen of Bede that the Celtic monks of Lindisfarne were in strict accord with St Augustine's "Italian Mission" at Canterbury.

$$
1 \text { Todd, "St Patrick," p. } 9 . \quad \text { 2 Beda, iv. } 27 .
$$



PART IV

\section{LITURGY AND RITUAL OBSERVANCES}





\section{CHAPTER I}

ORIGINS OF THE LITURGY

According to a well-known axiom: "Lex credendi, lex orandi," we may expect to find the doctrines believed in by the Celtic Church set forth in the liturgy which they used.

The scientific study of liturgy, although it has revealed much, has still a wide field in which to operate, but sufficient work has been accomplished to enable us to state with certainty a few facts about its origin.

Our Lord when instituting the Eucharist was content to provide for the essentials of a sacrifice and a sacrament. The task of developing the prayers and rites, enshrining the great mystery, He left to His Church. This development has been concerned with the five principal divisions of the Massnamely, the Preparation, the Offertory, the Consecration, the Fraction, and the Communion.

We are ignorant of the liturgical formulx which the first disciples carried with them 
on their missions to the Gentile world, but we gather from ancient writers that definite formula did exist at a very early date.

In a wide sense, liturgies are grouped into two families-Western and Eastern; or from a linguistic standpoint - Latin and Greek, the latter term covering several Oriental languages. Within these two great families the varied forms and ceremonies have developed along, practically speaking, the very same lines, but with considerable diversity. This general unity is indicative of a common source, dating, probably, from apostolic times. Leaving on one side the subject of Eastern rites, we may affirm, in company with the best authorities, that the liturgy in Western, or Latin, Christendom expressed itself in two different uses-the Roman and the Gallican (or Gothic) - and these two eventually became mingled.

The existence of these twofold uses in the West can be shown to date back to, at least, the end of the fourth century. At that time the Roman use was followed in Southern Italy and North Africa; the Gallican in Northern Italy (Milan), Gaul, and Spain. These two uses acted and reacted on one 
another during the seventh and following centuries, till at length a fusion of the two was effected. ${ }^{1}$

As to the origin of these uses diversity of opinion exists :

(1) Monsignor Duchesne traces the Gallican (or Gothic) to Milan, the Metropolitan See of North Italy, which See had patriarchal power and influence in the fourth and fifth centuries. The Oriental features of this liturgy may be accounted for, he tells us, in several ways, but especially because of the influence at Milan of Auxentius, a Cappadocian (355-374), as also by the presence of the Court and the numerous assemblies of Oriental bishops held there. ${ }^{2}$

(2) Other scholars believe that the Roman liturgy is the original of the Gallican, and that the Gallican formulæ are corruptions of the pure form preserved by Rome.

(3) Another theory lays down that the Roman use is the original of the Gallican, but that the Gallican books have preserved the older Roman form, whereas the Roman Mass has not. Be this as it may, one of the most expert liturgists of our day has

'Duchesne, "Origines du Culte Chrétien," c. 3.

${ }^{2}$ Irid. 
assured the present writer that "the kernel of the Roman liturgy is the oldest thing we have, and that the Gallican books show late formulæ."

Having premised thus much on a hotly debated subject, it may be affirmed with certainty that the Scoto-Celtic liturgy was but a form of the Gallican, or RomanoGallican, use.

In the list of the three orders of Irish saints given by Ussher, ${ }^{1}$ and dating from the eighth century, ${ }^{2}$ there are some valuable references to matters liturgical. Thus: "The first order of Catholic saints was in the time of Patrick . . . they observed one Mass, one celebration, one tonsure from ear to ear. The second order was of Catholic Presbyters. For in this order there were few bishops and many presbyters . . . they celebrated different Masses. . . . They received a Mass from Bishop David, and Gildas, and Docus, the Britons." (St Columba is named as belonging to this second, order.) "The third order of saints was of this sort: they were holy presbyters and a few bishops . . . and they had different rules and Masses and different tonsures."

1 Vol. vi. p. 477.

${ }^{2}$ Todd, "St Putrick," p. 88. 
The explanation of these curious references, as given by Lanigan and others, is that the first order celebrated Mass according to the rite introduced by. St Patrick (probably Gallican), and that the second order received a rite from St David, etc., of Wales, which was possibly a combination of the Gallican and Roman, while some of the clergy continued to say Mass according to the original rite given by St Patrick. ${ }^{1}$

According to an ancient liturgical tract, probably drawn up by an Irish monk in the seventh century, it is stated that St Patrick was taught letters by Lupus and Germanus, who by their commendation had him appointed archbishop of the Irish and Britons, and that he chanted "in Scotiis et Britanniis" the same liturgy as his spiritual masters. ${ }^{2}$

It is a remarkable fact that the liturgy of the Mass was never a subject of dispute between the Celtic and Roman missionaries. Therefore if any discrepancy existed it could not have been considered of any importance.

\footnotetext{
1 Lanigan, ii. p. 12, 13.

"Whitley Stokes, "Tripartite Life," p. cxcrii, ; also Moran, " Early Irish Church," p. 242.
} 


\section{CHAPTER II}

CELTIC LITURGY AND PAPAL SUPREMACY

ThE principal fragments of Celtic liturgy that have survived to our day are: the Stowe Missal, the Bobbio Missal, the Bangor Antiphonary, the Book of Deer, the Book of Dimma, and the Book of Moling.

1. The Stowe Missal. Monsignor Duchesne, following Warren, informs us that the texts of the Stowe Missal are in the handwriting of the eighth and tenth centuries respectively. ${ }^{1} \mathrm{Mr}$ Edmund Bishop (than whom there is, perhaps, no greater authority) thinks it represents the Mass as celebrated not later than the early years of the seventh century. Warren's reasons for assigning the Missal to the eighth and tenth centuries are very inconclusive. $\mathrm{He}$ himself, in his earlier book about the Corpus Christi Missal, assigned the two handwritings to the seventh and ninth centuries. The latest saint whose name is mentioned in the Canon

"Duchesne, "Origines du Culte Chrétien," p. 156. 
belongs to the early years of the seventh century.

The MS. of this Missal is in the library of the Royal Irish Academy. Dr MacCarthy edited it for the same Academy, and it appears as the twenty-seventh volume, No. VII. of the Transactions of that Society. On page 145 Dr MacCarthy tells us that the script is of a style older than the sixth century, and that the style of caligraphy has probably been preserved out of veneration for the MS. from which it was taken. The invariable Epistle and Gospel may represent the "unam missam" of the first order of saints, which was Gallican. ${ }^{1}$

The pages of the Missal are interpolated by a scribe called Moclcaich, who gives his name on folio 35A. Some pages he wholly cancelled, others only partially.

The objection to the existence of the name of Maclruen in the diptychs can be met by the fact that, even if the MS. was transcribed later than the seventh century, the age of the existing formulæ, and the compilation as a whole, are unaffected; but,

1 Prof. Bury draws attention to the Mass, which is the oldest part of the MS., dating to the first half of the fifth century (see pp. 164.5 of Dr MacCarthy), "St Patrick," p. 233. 
of course, the name may be a later interpolation.

Relying on the date assigned to this venerable MS. by $\mathrm{Mr}$ Edmund Bishop and $\mathrm{Dr}$ MacCarthy, it may be assumed to represent, with but few variations, the Mass as celebrated in the Celtic Church during the lifetime of St Columba. ${ }^{1}$

Almost every doctrine rejected by our separated brethren as "papal" is to be found enshrined in this ancient Celtic Massbook.

Adamnan informs us that "on one occasion, when the monks were putting on their shoes to go forth to their daily work, Columba ordered a holy-day to be kept, and he said that he himself would say Mass. Now, when in the chanting of the service that prayer was being sung wherein the name of St Martin is commemorated, suddenly the Saint said to the singers, who were coming to the mention of that name: "To-day you must sing for Bishop Colman.'"2 The question naturally arises, at which portion of the liturgy did this take place? Various an-

1 Rov. T. E. Bridgett, C.SS. R., "History of the Holy Eucharist in Great Britain," vol. i. p. 64.

2 Fowler's Adamnan, L. iii. 1 
swers have been suggested. Father Bridgett, C.SS.R., thinks that the insertion was made in the "Memento" for the Dead of the Stowe Canon, and Dr MacCarthy's note on the "Memento" bears out Father Bridgett's theory. The learned Doctor says: "As this prayer was undoubtedly choral, the pointing was employed to mark the pauses in the recitation, otherwise it is unmeaning." 1

In the prayer "Te igitur," with which the Canon Missæ begins, the Roman Pontiff is prayed for by name: "Una cum N. Papa nostro, episcopo sedis apostolicæ." And again, before the "Communicantes," supplication is repeated "pro Domino Papa" "for the Lord Pope." 2 Surely a conclusive proof that the Church of St Columba was in communion with the See of Rome, and acknowledged its authority.

Furthermore, St Peter is honoured in a special manner. The Collect preceding the "Gloria in excelsis Deo" runs thus: "O God, who by delivering to thy Blessed Apostle Peter the keys of the kingdom of heaven, didst bestow upon him the ponti-

1 “Transactions Royal Irish Academy," Vol. XXVII. vii. p. 215

2 Ibid. pp. 208, 209. 
fical authority to bind and to loose the faithful [animas]; mercifully receive our prayers, and grant us through his intercession the grace of being freed from the bonds of our sins." 1

This is no other than the Roman Collect for the feast of "Cathedra Petri" (The Chair of Peter) on the 18th of January - a feast intended to commemorate St Peter's episcopal supremacy. This festival is most ancient. It is noted in the Philocalian Calendar of the year 336. According to Monsignor Duchesne, the feast was introduced into Gaul at an early date. ${ }^{2}$ It is not surprising, therefore, to find this prayer of the Chair of Peter in this most ancient of Celtic missals. $^{3}$

Here, then, we have exemplified "Lex credendi, lex orandi." The Celts believed St Peter had received supreme authority, and in consequence they commemorated it year by year in the liturgy; for the "Cathedra Petri," as we have heard from St Columbanus, ever remained unshaken in the city of Rome.

1 MacCarthy's ed. of "Stowe Missal," p. 196.

" "Christian Worship," p. 278.

${ }^{3}$ In A.D. 567 the feast is mentioned at Tours, vide Bridgett, "History of Holy Eucharist," i. p. 34. 
One more point in the Stowe Canon Missæ is worthy of notice. In the commemoration prayer of St Martin, amidst a number of Celtic saints, there occur the names of the three archbishops of Canterbury-Lawrence, Mellitus and Justus, followed by that of Dagan. ${ }^{1}$ This is significant surely of the complete union in faith which existed between the Irish and the Roman Christians, considering that these three bishops were the very ones who addressed a somewhat sharp letter to the Irish Church on the question of Easter, and that Dagan was the actual bishop from Ireland who became so irritated at Canterbury that he refused to eat with the Roman prelates.

The Bobbio Missal. This Mass - book is another witness to the faith of the early Celtic Christians. Like the Stowe Missal, the Bobbio is also a MS. of the seventh century, and was brought to Gaul either by St Columbanus himself or by one of his disciples; hence the presumption that it represents the Mass as celebrated in his monasteries. ${ }^{2}$

The following opinion of $\mathrm{Mr}$ Edmund

1 Dr MacCarthy's ed. of "Stowe Missal," p. 217.

2 Lanigan, iv. pp. $272,374$. 
Bishop is of extreme importance:- "I am disposed to say that in the Bobbio Missal we have an example of the kind of book in vogue in the second age of .Irish saints." ${ }^{1}$

Since St Columba belonged to the second age of Irish saints, we have in the Bobbio Missal additional proof of what has already been stated regarding the Stowe Missal and Celtic belief and practice. St Comgall, the monastic superior of St Columbanus, and the friend of St Columba, belonged also to the second order of saints, who used the liturgy as represented by the Bobbio Missal.

The Bobbio Canon is entitled that of the "Missa cottidiana [quotidiana] Romensis," and is practically identical with the Canon of the Stowe Missal. Allowing, therefore, for variations arising from local causes, it is evident that the compilers of the Bobbio and Stowe Missals copied from the same source, which was current in the early years of the seventh century.

To the Bobbio Canon is prefaced the prayer: "Deus qui beato Petro, etc.," in honour of St Peter's pontifical authority. The Pope is prayed for by name in the 2 "Book of Cerne," note, p. 239. 
following manner: "Una cum devotissimo famulo tuo ill, Papa nostro, Sedis Apostolicæ" - "Thy most devoted servant N., our Pope of the Apostolic See." 1

Among the Masses occurring after the Canon is one for the feast of the "Chair of Peter," containing the following significant collect:- "O God, who on this day didst give to blessed Peter after Thyself the headship of Thy Church ... we humbly pray Thee that as Thou didst constitute him pastor for the sake of the flock, and that Thy sheep might be preserved from error, so now Thou wouldst save us through his intercession." A beautiful expression of Catholic doctrine, but absolutely opposed to the tenets of Protestantism. Let this prayer be read in the light of the Epistle of St Columbanus to the Pope, and it will be easy to perceive that the law of belief regulated for the Celts the law of prayer : "Lex credendi, est lex orandi."

This Missal, then, is a further proof, were it needed, of the full understanding the Irish monks possessed of the position of the Pope as head of the Church. Protestants often

${ }^{3}$ Rev. J. O'Laverty, "History of Diocese of Down and Connor," vol. ii. appendix. 
foolishly imagine that the Catholic Church ousts our Lord from His headship, and thrusts the Pope in His place. Needless to say, as is evidenced by the Bobbio Collect, the Church is no more guilty of this sin than is the Viceroy of India guilty of usurping the royal prerogatives of the British sovereign.

The Bangor Antiphonary is dated as belonging also to the seventh century. In this valuable MS. is to be found the hymn of St Sechnall written during the fifth century, in St Patrick's praise. It contains a direct. reference to the Church being founded on St Peter. This interesting stanza is thus literally translated by Cardinal Moran.1

" $\mathrm{He}$ [Patrick] is constant in the service of God, and immovable in the faith as Peter [Petrus], upon whom the Church is built, and whose Apostolate he received from God, against whose bulwark the assaults of hell cannot prevail."

The translations given by Ussher and Todd are shown by the Cardinal to be contrary to grammatical construction. ${ }^{2}$

'Moran, "Early Irish Church," p. 91.

2 The reading "Petrum," is to be found in Warren's edition of the "Antiphonary" for the Henry Bradshaw Sooiety. 


\section{CHAPTER III}

THE LANGUAGE OF THE LITURGY

To these testimonies to belief in papal authority from Celtic liturgy there must be added the important fact that Latin was used by the Celts for Mass, Office, and Sacraments, just as it is to-day by "Roman" Catholics. Had the ancient Scottish Church been an independent offshoot from Christianity then its services would never have been in the tongue of Rome, but in Gaelic, its vernacular. For, be it remembered, neither Ireland nor the northern part of Caledonia ever yielded to the dominion of the Roman Eagle.

If the early liturgy of the Celts had come direct from the East (as some have erroneously supposed), and not by way of Rome and Gaul, then it would have been in Greek, or some other tongue of the Orient. The stern fact, however, remains, that the liturgy of the Gaels was in Latin. Latin terms, and not Greek, have entered largely into the ecclesiastical vocabulary of the ancient (and, 
one might add, unchangeable) Gaelic of Ireland and Scotland. ${ }^{1}$ Even the anti-Roman Warren is forced to acknowledge that there is no trace of a vernacular liturgy having been in use in any portion of the Celtic Church. ${ }^{2}$

The use of Latin in the liturgy is often a cause of perplexity among non-Catholics, hence some explanation seems necessary. Latin is the official language of the Church in her liturgy and Councils for many reasons:

(1) It bears witness to the source whence Western Christendom derived the faith. For the Church adopted it when the Roman Empire was supreme, and her missionaries carried it with them in the official servicebooks.

(2) Being a dead language, it is not subject to change: it, therefore, preserves the perfect exactness of dogmatic decrees of Councils, so necessary in a perennial and unchangeable Church.

1 Hence: Easpuig from Episcopus, a bishop; Sagart from Sacerdos, a priest; Aifrioinn, the Offering-i.e. the Mass; Corp Chriosd from Corpus Christi, the Body of Christ in the Eucharist; Caigg from Pascha, Easter; Nollaig from Natale Christi, Christ. mas; Altaire from Altare, the Altar; Bachnll from Bacula, the crosier, etc. All indicative of the source of Celtic Christianity. They exist as records of an imperishable and indestructible conneetion with Rome.

"Warren, "Liturgy and Ritual of Celtic Church," p. 155. 
(3) It is a link of unity for the faithful in their worship and for the bishops with the Roman See; for a world-wide Church requires a universal language.

(4) It emphasises the Christian idea of sacrifice. The chief act of worship in the Catholic Church is the Mass, which, being sacrificial, is concerned more with what is being done than with what is being said. Christ is therein offered a sacrifice for the living and the dead. Prayer in this case accompanies the acts of the celebrating priest, and the faithful who are present are free to follow the great mystery according to their own devotion. 


\section{CHAPTER IV}

CELTIC PILGRIMAgES TO ROME

ONE of the most remarkable manifestations of Celtic allegiance to the Apostolic See was the almost continuous stream of pilgrims that travelled Romewards. This was particularly the case during the golden age of Columban monasticism.

$A^{\prime}$ journey to Rome in those remote ages was attended with no small amount of danger and difficulty. The amount of time it occupied was also very considerable. St Colman Elo allotted a year for news to be brought of St Gregory's death. ${ }^{1}$ St Cummian tells us that the deputies who went to Rome on the Easter question did not return till the third year after. Numbers who left these northern lands succumbed to the fatigue, and died on the way, and those who lived to return frequently did so despoiled and emaciated. ${ }^{2}$

A long catalogue might be drawn up of Celtic saints whose veneration for the Pope

'Salmon, "Aucient Irish Church," p. 52.

"Lingard, "Anglo-Saxon Church," ii. pp. 126, 127. 
led them to assume the pilgrim's garb, and go to Rome. Among the many who performed this act of devotion are numbered the following:-St Mochta of Louth, St Sechnall, St Ailbe, St Ibar, St Declan, St Kiaran of Saighir, St Alban, St Albert, St Abban, St Euda, St Carsan, St Senan, St Carthlach, St Gildas, St Nennidh, St Coulæd, St Barr, St Fursey, St Fridian, St Dagan, St Laserian, St Caidoc, St Monon, St Foillan, St Indracht, St Columba of Terryglass, St Colman of Dromore, St Colman Elo, St Cummian Fota, St Tighernach of Clones, St Conlon, St Flannan, St Macnissi, St Canice, St Wiro, St Plechelm, St Beoan, St Finnian of Moville, St Kilian, St Dichuill, St Roding, St Christicola, St Findchua, St Rumold, St Elias, St Silanus, St Hymelin, St Donatus ${ }^{1}$; not to mention St Ninian, St Kentigern, and St Nathalan of Aberdeen. These did not go as solitary pilgrims-many of their fellowcountrymen often accompanied them-and the journey was sometimes made more than once.

In some instances these holy pilgrims received either priestly ordination or episcopal

'Salmon, “Ancient Irish Church,” p. 63. 
consecration from the Roman Pontiff himself. Occasionally they took part in Roman Councils. Hence the Celtic pilgrim became so well known in Rome that St Colman, the tutor of St Cummian, thus expresses the fact in his seventh-century poem :

"If anyone went across the sea, To sojourn at the seat of Gregory,

If from Ireland, he requires no more than the mention of Cumine." 1

Now, what was the object of these constant visits to Rome? Ancient writings are silent as to mere curiosity and the spirit of travel, but when they do speak the reason assigned is either to learn the faith (as with St Ninian), or to seek counsel in the spirit of devoted children, as is mentioned by Cummian. ${ }^{2}$ In every case it was a visit of piety "ad limina Apostolorum "-_ to the threshold of the Apostles." Many such instances are quoted by Ussher. Gildas in his Life of St David says : "It was the custom at that time for the Irish to go on pilgrimage to Rome, to visit before anything else the "limina Apostolorum."

"Translated by Dr O'Donovan in "Ancient Irish Church," p. 55.

2 Vide Paschal Epistle.

"Düllinger, "History of Church," ii. p. 31. 
Rome was to the Celt what Mactheni assures us it was to St Patrick: "The Apostolic See, the head of all the churches of the whole world." ${ }^{1}$ But it would be difficult to assign the reason for these many pilgrimages more concisely than St Columbanus himself: "We [Celts]" he says, "are closely bound to the Chair of Peter. . . . For though Rome is great and renowned, through that Chair alone is it great and illustrious among us." ".

Had the Celts been unorthodox on the question of the divinely instituted authority of the papacy, instead of being welcomed to Rome they would have been repulsed as schismatical heretics.

Not only were these ancient Scots in active communion with the Apostolic See, but they communicated with all the Continental churches. In those far - off times laymen and ecclesiastics from Italy, Germany, Gaul, and Spain flocked to learn wisdom in the flourishing schools of Bangor, Clanmacnoise, Lismore, Clonard, Clonfert, and Hy. And when the Roman Empire had

'Bute, "Essays on Home Subjects," p. 50.

'Migne, P.L., vol. Ixxx. 
passed away, and barbarian hordes had spent their fury, almost all Europe witnessed the advent of countless bands of Celtic monks, who were bent on reaping a harvest of souls for God. Names such as Columbanus, Fridolin, Gall, Kilian, Livinus, and Fursey stand at the head of this list of apostles. The success of their work may be gathered from the fact that Celtic prelates occupied episcopal sees in Spain, Germany, France, Italy, and Switzerland.

How can these facts, from the sixth century onward, be explained if there existed doctrinal differences between Ireland, Caledonia, and the Continent? Would Frenchmen, Germans, and Italians have permitted themselves to be taught and shepherded by heretical monks and schismatical bishops? Identity of faith alone can explain this marvellous phenomenon.

It is notorious that the trifling matter of the date of Easter created no little opposition against St Columbanus in Gaul; but what would have been the outcry had he, or any other Celtic missionary, proclaimed unorthodox doctrine? But we know that Celtic monks never dreamed of such an enormity. 
Witness the words of St Columbanus to the Bishops of Gaul: "Pray for us, since we are all members of the one body [the Church], whether Gauls, or Britons, or Irish." ${ }^{1}$

${ }^{1}$ Migne, P.L., vol. Ixxx. 


\section{CHAPTER V}

THE CULTUS OF OUR LADY

In his Introduction to Adamnan's Life of St Columba, Dr Fowler informs his readers that in the Scottish Church at the time of Columba "we find no indication of the "worship' now offered to the Blessed Virgin and the Saints." ${ }^{2}$ Professor Cooper has formulated the same idea even yet more strongly. "It is important to note," he says, "that neither St Columba nor St Kentigern, two of our greatest saints, ever gave the-slightest sanction whatever to the worship of the Virgin Mary, that odious Mariolatry, which is so painful a feature of the modern Roman Church." 2

Leaving on one side the false and repulsive terms of this offensive statement, what have Professor Cooper and his friends got to show against St Columba and St Kentigern with regard to the Blessed Virgin? It is well

${ }^{1}$ p. Ixxvi.

"Lecture, Glasgow University, November 1898. 
known that nothing whatever is recorded of these two holy men that might lead anyone to suppose that they would hesitate for one moment to venerate the Blessed Virgin, just as Catholics venerate her to-day in Latin and Greek Christendom. ${ }^{1}$ Indeed, the extant lives of these two Saints witness to direct invocation of Our Lady and the blessed in heaven.

Non-Catholics have, as a rule, great repugnance to the cultus of Our Lady. ${ }^{2}$ Cardinal Newman in his Apologia informs us that certain extracts taken from the writings of St Alphonsus, and read by him before he was a Catholic, "prejudiced me as much against the Roman Church as anything else, on account of what was called their 'Mariolatry.' . . . Such devotional manifestations in honour of Our Lady had been my greatest crux as regards Catholicism. . . . They may be fully explained and defended, but sentiment and taste do not run with logic. ...

1 The devotion of the Universal Church towards the Blessed Virgin during the lifetime of St Augustine and St Jerome is demonstrated by Rev. John Freeland in his article, "The First Six Centuries," in The Dublin Review, April 1905.

${ }^{2}$ Most of these Protestant difficulties have been thoroughly dealt with by Cardinal Newman in his letter to Pusey, vide "Difficulties in Catholic Teaching" (Pickering, 1876). 
Only this I know full well now, and did not know then, that the Catholic Church allows no image of any sort, material or immaterial, no dogmatic symbol, no rite, no sacrament, no saint, not even the Blessed Virgin herself, to come between the soul and the Creator. It is face to face, 'solus cum solo,' in all matters between man and his God. He alone creates, $\mathrm{He}$ alone has redeemed; before $\mathrm{His}$ awful eyes we go in death; in the vision of Him is our eternal beatitude." 1

That non-liturgical devotions suitable to Italian taste were unacceptable to Newman as an Anglican one can well understand. After becoming a Catholic he writes thus: "I say frankly I do not fully enter into them now; I trust I do not love her the less, because I cannot enter into them." Herein we see illustrated the absence of rigid uniformity within the unity of the Church. The Southern nations express their devotional sentiments in one way, the more reserved Northern peoples make use of a more subdued or restrained method, yet both agree in their dogmatical belief.

Those who shout so loud about the excess 1 “Apologia," p. 194 (Longmans, 1883). 
of devotion to Mary are recommended to inspect the official service-books of the Catholic Church-viz. the Missal and Breviary. Apart from the "Ave Maria," said privately, a few occasional hymns, antiphons, and versicles, direct invocation of Our Lady is conspicuous by its absence. In the Mass there is not a single direct prayer to the Blessed Virgin. If we except the simple invocation of the Litany, there are none in the "Pontificale" either. And with regard to non-liturgical devotions to Mary, there is no obligation to use them; they depend entirely on the taste of each individual.

Then, again, all devotion to her, however exaggerated it may appear, must be of such a kind that it can be reduced to the "Ora pro nobis." If, for example, a manual contains an act of consecration to Our Lady, the most ordinary Catholic knows full well that such a prayer is to be understood in the mediate and not the immediate, or primary, sense-that is to say, the consecration made to her is intended to be passed on by her pure and powerful intercession to Almighty God. ${ }^{1}$

\footnotetext{
${ }^{1}$ It is wearisome to have to repeat time after time the refutations brought against Catholic teaching. The work has been done over and over again. See New man's "Difficulties in Catholic Teaching."
} 
Protestants frequently imagine that Catholic devotion to Mary is something cut off from devotion to our Lord, and therefore incompatible with that complete worship which is His due. We can assure our separated brethren that the contrary is the truth. The only claim of Mary to our homage is her intimate relationship with her divine Son. The cultus of the Blessed Virgin is only one aspect of the devotion of the Catholic Church to Jesus Christ.

It is an historical fact that the Catholic Church, which has persistently cherished a great love for the Virgin Mother, has ever been the great defender of the divinity of Christ her Son. Outside her fold, numbers of nominal Christians deny Christ's divinity because, among other reasons, their forefathers rejected the veneration of Mary.

Misrepresentation, calumny, and mistranslation of Sacred Scripture have been responsible for the repugnance of Protestants to devotion to Mary. Catholics honour Mary as the Mother of God and the greatest of saints; but they are aware that she is but a creature, and that, therefore, to adore or worship her as God would be detestable idolatry. Mary 
is what she is solely by the creative power of God. And where God has honoured so much we need not fear to follow. ${ }^{1}$

Protestantism having abolished the supreme act of worship to the Deity-namely, sacrifice -cannot distinguish between the honour due to the Creator and that which may lawfully be rendered to the creature. The Mass is offered to God alone; to offer it to any but God would be blasphemy. Catholics, therefore, by this act of sacrifice make an infinite distinction between their worship of the Son and the veneration they pay to His Holy Mother.

Devotion to Mary rests on the same basis as devotion to the saints; it differs not in kind, but only in degree. "I believe in the Communion of Saints" is our authority from the apostolic age. The unbroken tradition of the Church is expressed in the writings of the Fathers and in the decrees of General Councils.

St Irenæus of Lyons says: "As Eve was seduced to fly from God, so was the Virgin Mary induced to obey Him, that she might

1 On the development of devotion of Mary, see Dom Chapman, "Bishop Gore and the Catholic Claims," p. 32. 
become the advocate of her who had fallen."1 St Justin Martyr (145), Tertullian (200), and St Irenæus not only agree in declaring that Mary was the physical instrument of the Incarnation, but " an intelligent, responsible cause of it." St Jerome (331-420) thus summarises this teaching: "Death by Eve, life by Mary." 2

Volumes have been written on the cultus of the Blessed Virgin, historically and theologically considered; the regret is that our books so seldom fall into the hands of those who most require them. It is quite impossible here to quote Father after Father in support of the Catholic doctrine; but the reader who sincerely wishes for reliable information is urged to read monumental works like that of Father T. Livius (M.A., C.SS.R.), entitled "The Blessed Virgin in the Fathers of the First Six Centuries," ${ }^{3}$ or the volume called "The Woman Blessed by all Generations," by Father Melia (D.D., P.S.M.).

A singular impetus was given to Catholic devotion to Mary at the General Council of

1 Adv, Hares, V. xix.

2 Spencer Jones, "England and the Holy See," p. 307.

3 Burns \& Oates, 1893.

- Longmans, 1888. 
Ephesus, A.D. 431, when her title of "Theotocos "-Mother of God-was solemnly defined. Curiously enough, this Council was held under Pope St Celestine, and during the very year when that Pontiff despatched St Palladius to Ireland.

That veneration of our Lady existed in the Celtic Church at a very early period is clear from the writings of Gildas the historian (sixth century). He records the oath which Constantine, King of Damonia, uttered, first before God, then before all the saints, and also the Mother of God: "Genitrice." I In another passage Gildas speaks of himself as defended with "the double shield of the saints."

No one questions the intimate communion that was continually maintained between the Celtic monks and the Church in Gaul; it will, therefore, be of interest to learn that the first feast of the Blessed Virgin ever kept in Western Christendom found its way into the Gallican liturgy some time during the sixth century. Let the reader note that this was the period when St Columba, with the second order of Irish saints, received their

I Haddan and Stubbs, vol. i. p. 49. 
Gallican Mass from David, Gildas, and Docus. And the feast that came with this liturgy was intended to honour the Blessed Virgin as Mother of God. ${ }^{1}$

This fact is truly indicative that the movement initiated at Ephesus was a general one, in which the Celtic churches took part with the rest of Christendom.

As early as the time of St Jerome, the perpetual virginity of Mary was assailed by heretics. Its truth, however, is embodied in the Creeds of the Apostles and Nicra, composed after the departure of our Lady from this world. This same doctrine is clearly expressed in St Mochta's profession of faith, presented from Ireland to Pope Leo in the fifth century. ${ }^{2}$

The prayers of the Canon of the Mass are of an extremely ancient date; among the oldest is to be numbered the "Communicantes." This prayer is to be found in all missals, including the Stowe and Bobbio. It runs thus: "Communicating with, and venerating in the first place, the glorious ever-Virgin Mary, the Mother of God."

1 Duchesne, “Origines de Culte Chrétien," p. 258.

2 Moran, "Early Irish Church," p. 300. 
The doctrine of the sinlessness of our Lady, so emphatically upheld by St Augustine, ${ }^{1}$ finds place in the prayers of the ancient Celtic Church.

1. In a prayer ascribed to St Brendan of Clonfert (A.D. 584-577) is this petition: "Deliver me, O Lord, as Thou didst deliver Thy Mother, the most Blessed Virgin Mary, from all corruption." 2

2. In the Bobbio Mass for the Assumption of the Blessed Virgin, our Lady is saluted as the Virgin "full of grace."·3

3. In the prayer of St Colgu the Wise we find this petition: "I beseech the intercession, with Thee, of all the virgin saints of the whole world, with the Virgin Mary, Thy holy Mother herself." 4

In the Stowe Missal the opening invocation of the ancient litany of the saints is "Sancta Maria, ora pro nobis." But, perhaps, the most unique expression of ancient Celtic devotion towards our Lady is to be

`Vide Fr. Livius' "Blessed Virgin in Fathers of First Six Centuries," p. 211. "Now, with the exception of the holy Virgin Mary, touching whom, out of respect to our Lord, when we are on the subject of sins, I have no mind to entertain the question," ("De Nat. et Grat. c. Peleg.," 41).

2 Salmon, "Ancient Irish Church," p. 178.

3 Ibid. p. 181.

" Dr MacCarthy's “ Stowo Missal” notes, p. 179. 
found in a litany preserved in the Leabhar Breac, and which is attributed by the learned O'Curry to the middle of the eighth century, if not earlier. Dr Whitley Stokes inclines to a later date, but Cardinal Moran and other writers of repute adhere to the more ancient origin. That this early date is not incompatible with expressed devotion to Mary in the East, even in the seventh century, is evident from the words of $\mathrm{Mr}$ Edmund Bishop in his notes to the Book of Cerne.1

A full translation from the Gaelic of this beautiful litany is given by Cardinal Moran in his Essays. ${ }^{2}$ It is not possible to give here more than a few of the titles by which our Lady is therein saluted: "O Great Mary, O Mary greatest of Marys, O Queen of the Angels, O Blessed and Most Blessed, O Gate of heaven, O Temple of the Divinity, O Star of the sea, O Mother of God, O Crimson Rose of the Land of Jacob"; thereafter follows a prayer of considerable length, imploring the help of Mary's intercession.

Another practice of Celtic devotion, dating back to the sixth century, was the placing of children of both sexes under the special

"Vide "Book of Cerne." notes, p. 280.

${ }^{2}$ p. 224. 
patronage of the Blessed Virgin; hence the name of Mælmaire, which signifies "servant of Mary."1

Lastly, the many holy wells and churches bearing the name of Mary still surviving in Scotland and Ireland testify to this universal veneration for the Mother of God in ancient times.

Such were some of the practices of the Celtic Church, proving beyond a doubt that, if Catholic Christendom of to-day is tainted with the sin of "Mariolatry," the churches of Patrick, Columba, and Kentigern were guilty of the same evil practices.

I Salmon, p. 181. 


\section{CHAPTER VI}

VENERATION OF ANGELS AND SAINTS

The Catholic Church defines that the saints reigning with Christ pray for us, and that it is good and profitable to invoke them. The "Communion of Saints," if it means anything at all, means that there is intercourse between God's children in heaven and the faithful on earth by means of prayer. That the angels and saints are permitted by God to have knowledge of the things of earth is sufficiently evident in Holy Scripture. ${ }^{1}$ Moreover, our Lord assures us that the angels rejoice whenever a sinner turns to God by repentance. ${ }^{2}$ Repentance being a matter in which the will of man is concerned, it is obvious that the blessed spirits are aware in some way of our very thoughts.

The Catholic doctrine of the Communion of Saints was denied by the so-called Reformers of the sixteenth century. Thus they

${ }^{1}$ Gen. xlviii. 16 ; Tobias xii. 12 ; 1 Cor. iv. 9.

${ }^{2}$ Luke xv. 10. 
tried to sever the bond that unites the soul still in the flesh with the souls of the just, who now rejoice in God's heavenly presence.

The Celtic Church, in common with the rest of Christendom, venerated the angels and saints, as the following incidents show:-

(1) Fourteen years before the Life of St Columba was written by Adamnan a serious drought occurred. What did the monks do in order to obtain from God the necessary rain? The tunic and the holy books which had belonged to the Saint were brought out, and carried in procession round the open fields. And Adamnan adds: "Thus the invocation of the very name of the blessed man obtained rain for the parched earth."1

(2) On another occasion, when the monks were about to set out on a dangerous journey, they invoked their patron, St Columba, to obtain a favourable voyage, and the petition was granted. ${ }^{2}$ In subsequent chapters of the Life numerous instances occur of similar invocation.

(3) The third book of St Columba's Life ${ }^{1}$ Lib. ii. 44 (Fowler's ed.). ${ }^{3}$ Ibid. 45. 
is almost entirely taken up with records of his communion with the angels. Modern sceptics may sneer at what to them seems blind superstition, but the fact remains that the Columban monks, and St Columba himself, invoked the angels and saints in the same way as Catholics do now.

The liturgy of the Celts discloses the same doctrine and practice. For example, the Bangor Antiphonary (assigned to at least the seventh century) contains the following "popish" petitions :-

(1) "May Bishop Patrick pray for us all, that the sins which we have committed may forthwith be blotted out."

(2) "By the merits and prayers of St Comgall our Abbot, O Lord, preserve us all in Thy peace."

(3) "Mindful of Thy triumphant martyrs, we pray Thee that through their holy merits we may deserve the pardon of our sins."

(4) "In the invocation of the holy martyrs, O God, have mercy on Thy suppliants."

(5) " $O$ holy and glorious, wonderful and powerful martyrs, be mindful of us always in the sight of the Lord." 1

Bangor Antiphonary, H. Bradshaw Soc. 
The Bobbio Missal, of the same date, has special Masses for the feasts of SS. Michael, Stephen, James, John, John Baptist, Peter and Paul, and Martin; besides which, the names of thirty-one saints are mentioned in the prayer "Communicantes."

The Stowe Missal testifies to the same veneration. Its Canon honours the names of twenty-four saints; and prefixed to its "Ordinarium" is a Litany, in the seventhcentury handwriting, in which there is direct invocation of the Apostles. A second Litany, in the later handwriting, honours and invokes many Celtic bishops and confessors.

These evidences sufficiently prove the belief and practice of the ancient Celtic churches. ${ }^{1}$

${ }^{1}$ For a demonstration of Catholic derotion to angels, saints, and sacred relics in the sixth century, see Dublin Review, April 1905. 


\section{CHAPTER VII}

\section{HOLY RELICS}

Professor Zimmer, in his latest work on the Celtic church, thus delivers himself on the subject of relics: "Another symptom of the new spirit, which begins to pervade the Irish Church in the seventh century, after the first union with Rome, is the unprecedented extension which the cult of relics assumes." 1

It is difficult to understand why attention should be specially drawn to such a trivial matter. The early Irish Church either admitted the veneration of relics or it did not. If it did, as the Professor is forced to acknowledge, why make a fuss as to whether the relics venerated were of martyrs or confessors? In the Catholic Church the bodies of those renowned for sanctity are venerated equally with those who shed their blood. Their garments, their books, or anything else connected with the saints, 
are regarded as relics. Hence Zimmer is entirely wrong in saying that in Adamnan's Life of St Columba "nothing is said of relics, of the cult of relics, or of miracles effected by relics." 1 The contrary is the truth, as we shall presently show.

Now, what is the Catholic teaching on this subject? The Council of Trent declares that the holy bodies of martyrs and other saints now living with God are to be venerated by the faithful. ${ }^{2}$

The Protestant objection to the Catholic practice is as old as the time of St Jerome. Vigilantius, the heretic, called the Catholics of his time-of whom St Ninian was one"cinder-worshippers and idolaters." In the refutation, which St Jerome makes, occurs the following apposite passage:- "We worship not, we adore not, I do not say relics only, but not even the sun and moon, not angels, not archangels, not the cherubim, not the seraphin . . . lest we serve the creature rather than the Creator. But we

${ }^{1} \mathrm{P} .123$. Zimmer's inaccuracies have been sufficiently dealt with by Dr B. MacCarthy, M.R.I.A., in the Irish Ecclesiastical Record, November 1903. "The time is past," says Dr MacCarthy, "when statements of this kind can be made public amongst us with im. punity."

"Sess. $x x v$. 
honour the relies of the martyrs, that we may adore Him whose martyrs they are. We honour the servants, that the honour given to the servants may redound to the Lord." 1

The working of miracles by means of relics is not an occurrence peculiar to the time of St Columba, but it dates back to Moses and Elias, as the following examples show:-(1) The rod of Moses performed miracles at the Court of Pharao. ${ }^{2}$ (2) The mantle of Elias divided the waters of the Jordan. $^{3}$ (3) The bones of Eliseus the prophet caused a dead man to return to life again. ${ }^{4}$ (4) The hem of our Lord's garment cured a sick woman. ${ }^{5}$ (5) The linen cloths which had touched the body of St Paul cured divers diseases and banished evil spirits. $^{6}$ (6) The shadow of St Peter healed the sick and the possessed. ${ }^{7}$

All this is very much like what Adamnan tells us happened to the monks at Iona. The tunic of St Columba and his holy books were not only carried in solemn
Ep. ad Ripar, c. ix.
${ }^{2}$ Exodus vii. 10.
${ }^{3} 4$ Kings ii. 8.
4 Kings xiii. 21.
satt. ix. 20.
6 Acts xix. 12.
${ }^{7}$ Acts v. 15. 
procession, but miracles are related to have been wrought by God through their instrumentality. 1

Veneration of relics was no after addition to the faith at Iona. Palladius possessed a casket in which were preserved relics of the martyrs and of the Apostles SS. Peter and Paul. ${ }^{2}$ St Patrick also possessed several of these treasures. ${ }^{3}$

When the delegates sent to Rome from the Synod of Old Leighlin (A.D. 630) returned, it is expressly mentioned that they brought with them sacred relics of martyrs, through which a blind girl regained her sight, a paralytic walked, and many evil spirits were cast out. These things we learn on the authority of St Cummian in his Paschal Epistle.4

In the year 664, as Bede relates, St Colman, Bishop of Lindisfarne, on his departure for Iona and Ireland, carried with him a portion of the relics of St Aidan, his predecessor. $^{5}$

${ }^{1}$ Fowler's Adamnan, L. ii. c. 44, 45.

"Whitley Stokes, "Tripartite Life," i. pp. 30, 31 ; ii. p. 621.

${ }^{3}$ Salmon, p. 194 ; and Whitley Stokes, i. p. cxciii. ; also Bury, 151.

Migne, P.L., Ixxxvii. p. 978.

5 L. iii. c. 26. 
When St Columbanus wrote his first Epistle to Pope Boniface IV., he concludes thus: "Farewell, sweetest Father in Christ, be mindful of us in your holy prayers when you are near the ashes of the saints." In his second letter he has the same request to make of the Pope, but names especially the relics of SS. Peter and Paul. ${ }^{1}$

More might be added on this interesting subject, but the foregoing will suffice to demonstrate what the monks of Iona thought of the veneration due to sacred relics.

So long as Scotsmen and Englishmen gaze with respectful awe on the snuff-box of Burns and the old clothes of Nelson, they can hardly, with consistency, sneer at Catholics who venerate the relics of the saints who are the friends of God. ${ }^{2}$

${ }^{1}$ Migne, P.L., lxxx.

"On this subject the reader is directed to a dissertation by Father Brilgett, C.SS.R., in his "Dowry of Mary," p. 333. 


\section{CHAPTER VIII}

\section{SACRED IMAGES}

Closely connected with the veneration of relics is the honour shown to sacred representations. Christians from the apostolic age have been accustomed to depict sacred subjects on the walls of their churches, as the Catacombs of Rome testify. The Church has sanctioned the practice as a means to help the memory and imagination. It cannot be maintained that graven images were absolutely forbidden under the Old Law, since graven Cherubim, palms, and flowers, were used as ornaments of the Temple. Objects of this kind were prohibited to be made for the purposes of idolatry. On this point the Catholic Church asserts most plainly that her children do not pray to images, "for they can neither see, hear, nor help us." 1

The Celtic Church in this matter followed the practice of Catholic Christendom. The Cross was held by the monks at Iona "Vide "The Catechism of Christian Doctrine" used in Catholic schools. 
in special veneration. St Columba is said to have erected and blessed numbers of them. Some of his crosses remain to this day.

In the famous Book of Kells, written by St Columba's own hand, is to be seen a representation of our Lord, His hand raised in blessing, and another of the Blessed Virgin with her divine Child. ${ }^{1}$

In the churches of Gaul, during the sixth century, it was customary to represent our Lady seated in a chair, holding our Infant Saviour in her arms. ${ }^{2}$ Doubtless the practice found its way into Britain and Ireland at the same period, as the Book of Kells seems to indicate.

As to the objections which are made against external acts of reverence before sacred pictures and images, they are generally founded on misunderstanding. So long as British subjects bend the knee before their sovereign, or make obeisance towards an empty throne, there should be no difficulty in understanding a genuflection before a crucifix or a bow of the head before a statue of the Blessed Virgin.

1 Salmon, p. 204.

2 Opera Greg. Tours, Mirao. i. 10 ; Migne, P.L., Ixxi. p. 715. 


\section{CHAPTER IX}

PRAYER FOR THE DEAD

THE Catholic idea of the Communion of Saints brings together in one great family the blessed in heaven, the faithful on earth, and the souls in purgatory. In purgatory the residue of penitential satisfaction is undergone if full amends have not been made during life on earth.

Beyond the fact of the existence of purgatory, and that it involves a delay in entering heaven till the last remains of sinfulness are purged away, we know nothing with absolute certainty. Of the duration of time there we are not told, but we do know that our prayers and good works can, and do, help the souls of those therein detained; hence the practice of intercessions and Masses for the departed.

The Scriptural and patristic proofs of this doctrine need not be here quoted $;^{1}$ suffice it to say, purgatory formed part

1 These may be found in Waterworth, "The Faith of Catholics," iii. 14. 
of the belief of the Celtic Churches, as the following references prove :-

(1) St Columba ordered prayers for the soul of Bishop Columbanus, and on the occasion ${ }^{-1}$ himself celebrated Mass. ${ }^{1}$

(2) St Cummian in his Penitential directs that for the soul of a departed monk Mass shall be offered on the day of burial, and on the third day afterwards. ${ }^{2}$

(3) The Bobbio Missal gives the following prayer in the Canon Missæ:- "Remember also, $O$ Lord, the names of those who have gone before us with the sign of faith, and sleep in the sleep of peace... To these, and to all resting in Christ, grant, we beseech thee, a place of refreshment, light, and peace." 3 The same petition occurs in the Stowe Canon, besides which special Masses for the Dead are set down.

(4) In an ancient Celtic Rule, attributed to St Columba, a monk's obligation towards the departed is thus expressed: "Fervour in singing the Office for the Dead, as if every faithful dead person was a friend of thine own."

'Howler's Vita S. Columba, I. iii., c. 12.

${ }^{2}$ Migne, P.L., lxxxvii. p. 998.

"O'Laverty, " Diocese of Down and Connor," ii. appen. v.

- Haddan and Stubbs, ii. p. 120 ; vide also Whitley Stokes, "Tripartite," p. cxciv. 


\section{CHAPTER X}

THE HOLY EUCHARIST

Catholics believe that when the formulas of consecration are pronounced by a priest over the bread and wine in the Mass, the words of Christ: "This is my Body; this is my Blood," are literally fulfilled, so that what were previously bread and wine become really and truly Christ's Body and Blood. No deception of the senses takes place, for the act is an invisible miracle. This mystery is usually termed Transubstantiation.

We possess ample evidence that the Celtic monks believed the Eucharist to be the true Body and Blood of our Lord, and also a real sacrifice for the living and the dead.

(1) When St Columba was still a deacon he changed water into wine for "the mystic sacrifice" offered on the altar, as Adamnan informs us. ${ }^{1}$

${ }^{2}$ Lib. ii. 1. This and the following refer to Fowler's edition of Adamnan. 
(2) Among the terms employed to designate the Mass in St Columba's Life by Adamnan are these: the solemn Offices of the Mass $^{1}$; the Mystic Sacrifice ${ }^{2}$; the consecration of the Body of Christ $^{3}$; the celebration of the Holy Mysteries of the Eucharist ${ }^{4}$; the consecration of the Holy Oblation. ${ }^{5}$ It would be difficult to express in clearer terms the true Catholic doctrine. What Presbyterian minister or non-ritualistic clergyman would presume to employ such words to designate his Communion service? The terms Mass and Sacrifice are inseparably connected with the doctrine of Christ's Real Presence in the Eucharist.

(3) The Bangor Antiphonary provides a hymn to be chanted while Holy Communion is being received, the first strophe of which runs thus: "Come, ye holy ones, take the Body of Christ, drinking the sacred Blood by which ye were redeemed." "The reader may be left to form his own conclusion as to the nature of Sacramental doctrine thereby conveyed. Yet this was accepted by the immediate disciples of St Comgall.

\footnotetext{
'i. $40 .{ }^{2}$ ii. $1 . \quad{ }^{3}$ i. $44 . \quad$ iii. $17 . \quad{ }^{5}$ iii. 17.

- "Bangor Antiphonary," Henry Bradshaw Society, p. 10.
} 
(4) The Penitential of St Columbanus has these words: "For the Altar is the tribunal of Christ, and His Body even there with His Blood judges those who approach unworthily." 1

Many such references might be multiplied, but these may suffice to convince the reader that the Early Celtic Church believed not only in the Eucharistic Presence of our Lord, but accepted the doctrine of the Mass also. ${ }^{2}$

A few years ago Iona was the scene of centenary celebrations in honour of $\mathrm{St}$ Columba. Services were held; sermons were preached, prayers were said, and hymns sung, but only one body of pilgrims ventured to offer Sacrifice. Catholics alone did what Adamnan affirms St Columba did-i.e. celebrated "the solemn Offices of the Mass." Catholic bishops were there to assist at "the clean mysteries of the Holy Sacrifice." Complete continuity with the past was further demonstrated by the presence of monks with their presbyter-abbot, who chanted, as in the days of old, the liturgy

1 Migne, P.L., vol. Ixxx. p. 230.

2 The Eucharistic belief of the Universal Church during the first six centuries is demonstrated in The Dublin Review, April 1905.

3 iii. 17. 
in the Latin tongue. The Eucharistic Presence on the Altar that day was adored by faithful Gaels, whose proud boast it was that the faith they held had come down to them undefiled by heresy from the times when St Columba delivered it to their sixthcentury forefathers. And, above all, the continuity with the past of that historic assemblage consisted in the unbroken chain which linked them to the Chair of Peter, a bond which St Columbanus, the fellowcountryman and contemporary of St Columba, had so eloquently extolled in his message to Pope Boniface. 


\section{CHAPTER XI}

COMMUNION UNDER ONE KIND, AND OTHER OBSERVANCES

THE Catholic Church teaches her children that, under either species in the Eucharist, Christ is received whole and entire. Both species are necessary for the accomplishment of the Sacrifice, but only one for a perfect communion; hence in the Celtic Church Communion was sometimes administered under one form only. This we gather from the Rule of St Columbanus, wherein it is prescribed that novices shall not be permitted to receive the Chalice. ${ }^{1}$

In the same Rule, forty days of penance is imposed on those who while, on a journey, fall into the water, and let drop the vessel containing the Sacred Host. Thereafter the traveller is himself to drink the water that has entered the pyx, and the sacred particle is to be reverently consumed. Father Bridgett rightly concludes that from these regulations

1 Migne, P.L., lxxx. col. 220. 
it is evident that monks carried the Holy Eucharist under the species of bread alone. ${ }^{1}$

Other matters regarding the Eucharist may be here briefiy mentioned.

(1) Fasting before Communion is thus referred to in Cummian's Penitential: "Let him who shall have taken the Sacrifice after food do penance for seven days." ${ }^{2}$ It may also be inferred from the early hour at which Mass was celebrated at Iona.

(2) Those who approached the Altar to receive the Blessed Sacrament were required by the Rule of Columbanus to bow thrice. ${ }^{3}$

(3) Reservation of the Blessed Sacrament is spoken of in the same Rule, and also it is presupposed by the number of instances of receiving it at the hour of death.

In a fragment of Scoto-Celtic liturgy not later than A.D. 800 there is a form for giving Communion to the sick quite apart from Mass. The Gaelic rubric directs: "Here give the Sacrifice to him"; and the words of administration were: "The Body with

1 Migne, P.L., lxxx. col. 220; and Bridgett, "History of the Holy Eucharist," p. 61. The disciplinary law of communion under one kind for Latin Catholics dates from the year 1414.

${ }^{2}$ Quoted by Salmon, p. 83, from Wasscrschleben, p. 493.

3 Migne, P.L., lxxx. c. 220. 
the Blood of our Lord Jesus Christ be health to thee to life eternal and to salvation." It is very improbable, says Father Bridgett, that the Eucharist was carried from the church in both species; and the form, "The Body with the Blood," can be explained as testifying to the belief that both are present under one species. ${ }^{1}$

(4) In the Celtic Church unleavened bread in the form of a circular Host was used at Mass. Water, too, was mingled with the wine. And Mass was celebrated daily. ${ }^{2}$

(5) Special vestments were used at Mass, and these were of various shades. In the Leabhar Braec eight colours are mentioned. ${ }^{3}$ In the Book of Deer two Gaelic priests are depicted attired in chasubles. ${ }^{4}$ At Iona on festivals the monks wore white garments. ${ }^{5}$

(6) Lighted candles were used during Mass, and an acolyte was styled the "Caindloir." 6

(7) Incense was also used. It is referred to in the Annotations of Tirechan in the Book

1 “History of the Holy Eucharist," p. 66.

2 Salmon, p. 92; Whitley Stokes, "Tripartite Life," p. clxxxvi.

${ }^{3}$ Ibid.

4 Bridgett, p. 66.

${ }^{5}$ Fowler's Adamnan, L. iii. c. 12.

${ }^{6}$ Salmon, p. 98. 
of Armagh and in the ancient Irish glosses quoted by Dr Whitley Stokes. ${ }^{1}$ Mention of a thurible occurs in an old Latin Life of St Tighernach of Clones. ${ }^{2}$

(8) Churches were consecrated before Mass was said within them, ${ }^{3}$ and everything connected with the sacrifice was hallowed with a blessing. Thus in the Bobbio Missal we find blessings for the chalice and paten, and the "turris," or vessel for reserving the Eucharist. Altars were consecrated, and had five crosses incised on the slab. ${ }^{4}$

(9) Linen altar cloths are mentioned by Cummian, and the chalices and patens were of various materials. ${ }^{5}$

(10) Holy water is referred to in the Life of St Patrick and in that of St Columba. ${ }^{6}$ In the Bobbio Missal the form for blessing it prescribes the mingling of salt. ${ }^{7}$

(11) Blessed bread, apart from the Holy Eucharist, was used by St Columba, as is

I Whitley Stokes, “Tripartite," i. cxcii. ; ii. 306.

2 Salmon, p. 228.

3 Haddan and Stubbs, ii. P. II. p. 329.

- Migne, P.L., lxxii. p. 571 ; and Salmon, p. 100.

5 Whitley Stokes, i. p. clxxxvi.

6 Ibid. p. cxciv. ; and Fowler's Adamnan, L. ii. p. 77.

7 Migne, P.L., Ixxii. p. 567. 
done in certain Catholic countries at the present day. ${ }^{1}$

(12) The form for blessing palms is laid down in the Bobbio Missal. Exorcisms, to be said over the possessed, are to be found in the Bangor Antiphonary.

(13) The practices of striking the breast, genuflecting and prostrating, as acts of devotion, are often mentioned among the ancient Celts. ${ }^{2}$

(14) Feasts and their octaves were kept in the Celtic churches. Christmas and Easter were celebrated at Iona. ${ }^{3}$ Easter, called a "Feast of Gladness," was extended till the Ascension. St Columba died on the Octave of Pentecost, according to the Irish Annals. Before Adamnan's time, the feast and vigil of St Columba were observed at Iona. ${ }^{4}$ The Octaves of the Epiphany, Easter, and SS. Peter and Paul are referred to in the ancient lives of Celtic saints. ${ }^{5}$

(15) Besides the Mass, other services-the canonical hours--were observed by Celtic monks. At Iona the daily office consisted

1 Fowler's Adamnan, ii. 4.

2 Whitley Stokes, p. cxcv.

3 Fowler's Adamnan, ii. 9.

4 Ibid. ii. 45.

5 Salmon, p. 220. 
at least of Matins, Vespers, Tierce, Sext, and None. ${ }^{1}$

(16) Regarding the sign of the Cross, Tertullian in the second century tells us; "At every step, at every movement, when we go in or out; when we dress or put on our shoes, at the bath, at table; when lights are brought, when we retire to bed, when we sit down, whatever we do, we mark our foreheads with the sign of the Cross." 2

Frequent mention is made of the same practice among the ancient Celts. St Patrick, according to Mactheni, made the sign of the Cross very frequently. ${ }^{3}$ According to the Rule of St Columbanus, the monks were required to make the Cross over their spoons, over lamps when they lighted them, when walking, when going in or out, or on commencing any work. ${ }^{4}$

St Columba was accustomed to use the sign of the Cross. ${ }^{5}$ During Mass it was made at places indicated by a cross-mark in the

I Fowler's Adamnan, iii. 23; ii. 45; i. 35; Whitley Stokes, p. excii.

2 Opera Tertull., "Do Coron. Mil." 3, 4.

3 Whitley Stokes, p. cxciii.

- Migne, P.L., Ixxx. c. 216, 220, 223.

-Vide Fowler's Adamnan, p. 85, 123, otc.; Bellesheim, i. 105. 
Canon, as exhibited in the Stowe and Bobbio Missals. It also formed part of the ceremonial in the administration of the Sacraments, as evidenced in the Book of Dimma and elsewhere. ${ }^{1}$

1 Warren, "Liturgy of Celtic Church," p. 171. 


\section{CHAPTER XII}

CONFESSION

Catholics hold that when Christ pronounced the words: "Receive ye the Holy Ghost; whose sins ye shall forgive, they are forgiven them; and whose sins you shall retain, they are retained," $1 \mathrm{He}$ bestowed upon the Apostles, and through them upon their successors, that power of absolution which is exercised in the Sacrament of Penance. As the Sacrament of Baptism was instituted to remove original sin, that of Penance was ordained for the remission of actual, or postbaptismal, sin. Sincere sorrow, confession, and a firm purpose of amendment are requisite for a valid reception of this Sacrament.

Auricular Confession was believed in by St Columba and his monks. It is related that on one occasion the Saint sent a monk all the way to Ireland to induce a woman to make confession of a sin she had concealed. After penance she was absolved. ${ }^{2}$

${ }^{1}$ John $\times x .22$.

${ }^{2}$ Adumnan, i. 17 (Fowler's). 
On another occasion, Feachna came to Iona from Ireland to make his confession to St Columba, from whom he received absolution. ${ }^{1}$ We are also told of a man who was obliged to confess, because God had revealed to the Saint his secret crimes. ${ }^{2}$ Another Irishman, who came to Iona on pilgrimage, confessed his sins, and kneeling before the Saint promised to fulfil "the laws of penance." 3

According to Protestant theology all this was very unbecoming and very unnecessary. It would have sufficed to confess in the secret chamber of the heart to God alone; but evidently St Columba thought otherwise, and so did his monks.

The practice at Iona receives confirmation from the practice of Ireland. For instance, according to the Rule of St Mælruain, to divulge what had been heard in confession was to commit one of the four enormous crimes not received to penance in Erin.4

The following is from the Penitential of

3 Adamnan, i. 30.

${ }^{2}$ Ibid. i. c. 40.

3 Ibid. i. 22.

"Whitley Stokes, "Tripartite," p. clxiv. 
St Columbanus :- "It is ordered that confession be given with all diligence, especially concerning commotions of the mind, before going to Mass, lest perchance anyone approach to the Altar unworthily." 1

The confessor was known in Gaelic as the "Anam-chara," soul-friend. The Gaelic proverb: "Body without head is man without confessor," indicates the importance attached to the practice of confession. ${ }^{2}$

${ }^{1}$ Migne, P.L., lxxx. col. 230.

${ }^{2}$ Whitley Stokes, "Tripartite Life," p. clxiv. 


\section{CHAPTER XIII}

\section{PENANCE AND FASTING}

Closely connected with confession of $\sin$ is the doing of penance. It is manifest in Holy Scripture that God frequently freed the penitent from the guilt of $\sin$ and its eternal punishment, without, however, remitting the temporal punishment. ${ }^{1}$ Thus after confession the penitent is asked to perform works of penance-(1) that he may the better realise his guilt before God; (2) that he may thereby pay the debt of temporal punishment still often due to forgiven sin.

Over and above this, at stated times, the Church enjoins penitential exercises, such as fasting and abstinence-apart from voluntary mortifications-in order that the flesh may be mortified, and so kept subject to the spirit, for Christ's sake. Our Lord foretold that His people would fast after $\mathrm{He}$ had left

${ }^{1}$ e.g. Adam, Gen. iii. 17 ; rebellious Jews, Num. xiv. 20 ; Moses, Num. xx. 12 ; Deut. xxxii. 51 ; David, 2 Kings xii. 13. 
them, and the Apostles were the first to fulfil our Saviour's words. ${ }^{1}$

At Iona, when a penitent came to confession he was said to "agere pœenitentiam "to do penance. Occasionally the laws of penance, and the penitents themselves, are referred to. ${ }^{2}$

Fasting was very common with the Columban community. Wednesday and Friday of each week were observed as fasts. The forty days of Lent were kept in like manner; ${ }^{3}$ in fact, the whole work of Adamnan bears witness to the universal practice, and the utility of fasting. With regard to St Columba himself, his biographer asserts that he was constantly engaged in the unwearied exercise of fasting and watching. ${ }^{4}$

St Aidan introduced into Northumbria the practice of fasting till the ninth hour (three o'clock) on Wednesdays and Fridays."

St Patrick's habitual fasts are constantly referred to in the most ancient documents. ${ }^{6}$

The lives of the Celtic saints were uni-

1 Matt. ix. 15 ; Mark ii. 20 ; Acts xiii. 3 ; xiv. 22 ; xxvii.

2 Fowler's Adamnan, L. i. 21, 22.

${ }^{3}$ Ibid. ii. 39.

- Pref. Adamnan.

5 Beda, iii. 5.

5 Haddan and Stubbs, ii. p. 406 ; Whitley Stokes, cxcv. 
formly noteworthy on account of their extreme penance. Some recited the psalms while immersed in cold water; others, like St Columba, took their brief repose on a bare stone. ${ }^{1}$

Lastly, the Bobbio Missal provides special Masses for the season of Lent, in which the omission to fast is spoken of as sinful.

${ }^{1}$ Whitley Stokes, p. cxcvi ; Salmon, 215. 


\title{
CHAPTER XIV
}

\author{
CONFIRMATION
}

W ITH the rejection of the episcopal form of government, Presbyterian Scotland discarded the Sacrament of Confirmation. It, therefore, may be expedient to adduce the testimony of the Celtic Church in proof of its acceptance of this sacred rite. ${ }^{1}$

In the Cottonian MS. of the Confession of St Patrick, the Saint refers to the perils braved by him in certain parts of Ireland, "where no one had ever come to baptise, to ordain clergy, or confirm the people." 2 Again, in his Epistle to Coroticus, St Patrick complains that innocent Christians whom he had "begotten to God without number [i.e. through baptism], and confirmed in Christ," were cruelly slaughtered, "even while the chrism of the neophyte was still showing on their foreheads." ${ }^{3}$ Relative to this latter

The Scriptural authority for.confirmation is to be found in Acts viii. 14.17 ; xix. 6 ; 2 Cor. i. 21.

2 Whitley Stokes, “Tripartite," i. p. clxxxiv; ii. p. $357,375$.

${ }^{3}$ Ibid. 
remark, the reader must bear in mind that the holy oil, called Chrism, is used by Catholic Bishops in confirmation, and in former times this Sacrament was conferred as soon as possible after baptism.

Confirmation is also spoken of in the Penitential of St Cummian : "It is lawful," according to this code, "for bishops to confirm in the open country." 1

In the eighth-century Collection of Irish Canons, called "Hibernensis," the duties of a bishop are thus enumerated: "To judge, to interpret, to consecrate, to confirm, to ordain, to baptise, and to offer." 2

${ }^{1}$ Quoted by Salmon, p. 71, from Wasserschleben, p. 26.

${ }^{2}$ Ibid. 


\section{CHAPTER XV}

EXTREME UNCTION

THAT the Sacrament of Extreme Unction, or, as the Gaelic sometimes expresses it, "The Sacrament of Oil," is of divine institution, besides the authority of the Church, we possess the testimony of St James the Apostle. ${ }^{1}$ How Bible-loving Protestants manage to evade this very clear and definite statement it is not easy to understand.

Certain Celtic scholars of recent times have considered that the earliest mention of Extreme Unction in Gaelic documents belongs to the twelfth century. But this is obviously a mistake.

In the Book of Dimma, assigned to the seventh century, there is a Mass for the sick, in which the form for anointing is set down thus: "I anoint thee with holy oil, in the name of the Trinity, that thou mayest be saved for ever and ever." 2

1 James v. 14, 15.

${ }^{2}$ Warren, "Liturgy of Celtic Church," p. 169. 
In the Book of Moling (seventh century) is given: "I anoint thee with the oil of sanctification, in the name of the Father, and of the Son, and of the Holy Ghost, that thou mayest be saved in the name of the Holy Trinity." 1

In the Stowe Missal we find this form: "I anoint thee with holy oil, that thou mayest be saved, in the name of the Father, and of the Son, and of the Holy Ghost, for ever."?

Nothing is prescribed as to the parts to be anointed, but from the wording of the above formulas it would appear that a single unction was the Celtic custom.

1 Warren, "Liturgy of Celtic Church," p. 172.

2 Ibid. p. 223. 


\section{CHAPTER XVI}

\section{CLERICAL CELIBACY}

OF its very nature, monastic life presupposes the observance of chastity, obedience, and poverty. Adamnan informs us that novices at Iona during St Columba's lifetime were required to take a monastic vow. ${ }^{1}$ So strictly was this vow binding on the part of the monk, that if afterwards he abandoned his monastery, and contracted marriage, he had to do penance for a space of ten years - three of which were devoted to fasting on bread and water; and he was never more to enter the married state-a rather unlikely contingency, one would be led to imagine. Should he be unwilling to submit to this course of penance, then the monk was to be excommunicated by the Holy Synod, or even by the Apostolic See. ${ }^{2}$

Celibacy, as a disciplinary law of the Western Church, is of general observance for all the higher grades of the clergy. In

${ }^{1}$ Fowler's Adamnan, i. 32. $\quad 2$ Migne, P.L., lxxxv. col. 985. 
the East the law is somewhat different. There, although marriage cannot be contracted by a secular priest, or a deacon, after ordination, a clergyman may continue to live with the wife he had wedded before the reception of Holy Orders.

The law of celibacy has been imposed by the Church with a view to the dignity and duties of the priesthood. Our Lord Himself thus commends the state of virginity: "All men take not this word, but they to whom it is given... He that can take let him take it." ${ }^{1}$ St Paul enunciates the same teaching: "He that giveth his virgin in marriage doth well, and he that giveth her not doth better." 2 The same Apostle gives us practical reasons why the Catholic priesthood observes celibacy.

If anyone should say that the observance of this counsel of St Paul is an impossibility, it would be equivalent to an accusation of false teaching, and would at the same time stigmatise countless numbers of the unmarried with lives of sinfulness.

In the Catholic Church the life of celibacy is chosen voluntarily by those who enter the

${ }^{1}$ Matt. xix. 11-13.

${ }^{2} 1$ Cor. vii. 
clerical and religious states and are sufficiently advanced in years to understand the nature of the undertaking-and this is done in order to be more at leisure to serve God and one's neighbour.

It would, however, be a fatal mistake to imagine that, because clerical celibacy is enforced, the state of marriage is consequently lowered. The contrary is the case: the Catholic Church regards matrimony as a Sacrament of Jesus Christ, and, therefore, holy in itself and in all its relations. How unwarrantable, then, are the following words of a leader of the United Free Church :-_ "But the mistake involved in holding the unmarried state in itself better than the married (which emphatically it is not) became the source of almost boundless evils . . . it affixed a note of moral inferiority upon the state of marriage; it became the occasion of leading many persons into a snare which ruined them." 1

Celibacy was not only maintained as an essential of monastic life in the Celtic Church, it was also observed by the higher orders of clergy. The Penitential of St Cummian, for

1 Reported of Principal Rainy in The Scotsman. 
example, enacts that if a bishop, priest, or deacon, having been married before ordination, should again return to the married state, by living with his wife, he shall be adjudged guilty of adultery, and do penance for his crime. A subdeacon guilty of this offence must fast for two years on bread and water, and for four years must perform public penance; if a deacon, or of a higher grade still, he must for three years, or more according to his rank, fast on bread and water, and spend a still longer time in public penance. ${ }^{1}$ The same severe enactments are to be found in the Penitential of St Finnian, and in that of the Bobbio Missal.

Moreover, in a Council held at Tours, in 461, in which British bishops took part, strict discipline regarding clerical celibacy was enacted. The Canons were signed by the British, as well as by all the other bishops. In 567 another Council was held at Tours, and the law of celibacy regarding clerics married before ordination was re-enacted. ${ }^{2}$

Against the foregoing, it is sometimes urged by Protestants that St Patrick's father and

${ }^{1}$ Migne, P.L., Ixxxvii, col. 985.

2 Bridgett, "History of Holy Eucharist," pp. 31, 33. 
grandfather were in holy orders, and certain Irish Canons refer to the wives of clerics.

In explanation of these seeming contradictions the following may suffice :-

(1) Although St Patrick's father and grandfather were deacon and priest respectively, it does not follow that they were living the matrimonial life at the time they discharged their clerical duties. Men who have been married are not infrequently raised to the priesthood and the episcopate, and this even in our own time. Quite recently a priest who is a widower presided in Rome at the religious profession of his own daughter.

(2) In early times it sometimes happened that married laymen, who had won the esteem of the people in civil capacities, were suddenly elected to the episcopal office; while the minor clerics to whom marriage was lawful were on the promise of continence advanced to Holy Orders. ${ }^{1}$

(3) Be that as it may, St Patrick himself was a celibate, ${ }^{2}$ and, moreover, encouraged celibacy armong his Irish converts, as he tells

1 The Celibacy of the Celtic clergy is demonstrated in Döllinger, vide "Church History," vol ii. p. 33.

2 Vide Hymn of St Seohnall in Antiphonary of Bangor. 
us in the Confession: "Sons of the Scots and daughters of chieftains are seen to be monks and virgins of Christ." The same fact is alluded to in the Saint's Epistle to Coroticus. ${ }^{1}$

(4) With regard to the synodical Canon of St Patrick "if his wife does not walk with her head veiled, let them [i.e. the cleric and his wife] be despised by the laity, and also separated from the Church."

It is incredible that the Penitentials, above quoted, and the Patrician Canon should be in such absolute contradiction. The wife may refer to one taken before ordination, and from whom the cleric had to withdraw after ascending the higher grades of orders. It may signify that such a wife had to make religious profession, as was, and is, the Canon law of the Church for the wife of a man who aspires to the priesthood. But Cardinal Moran has pointed out that there is a second reading of this Canon-the oldest and best MS.-in which the word ejus, his wife, is not to be found. The Canon would then read: "If a wife [i.e. any married woman] does not walk with her head veiled, etc." This veiling was a Roman law, probably introduced

1 Whitley Stokes, ii. pp. 369, 378. 
by St Patrick at the time he enforced clerical dress for the clergy. ${ }^{1}$

Polemical writers have imagined that St Celsus, Primate of Armagh, was married because St Malachy had a vision in which the church of Armagh was personified as "the wife of Celsus." To such absurdities will prejudice lead.

Objections to celibacy among the Celtic clergy have sometimes been alleged because of persons bearing names indicating they were sons and daughters of abbots, priors, etc. These, however, must vanish when it is remembered that an abuse of monastic government widely prevailed in Ireland and Scotland during the Middle Ages. Mere laymen often held the titles of abbeys and monasteries, in order to draw the revenues, while the ecclesiastical duties were performed by a deputy. Hence such names as M'Nab, "son of the Abbot," etc.

At the present day the owner of Battle Abbey is its titular Abbot, and the Earl of Kilmory is similarly Abbot of Newry, yet these proprietors are neither clerics nor monks.

'Moran, " Early Irish Church," p. 309. 


\section{CHAPTER XVII}

THE MEDIEVAL CHURCH

ST Margaret is accredited with having inaugurated a policy of "Romanising" the Church of Scotland, which was brought to completion by her son, King David. Now what are the facts that have given rise to this groundless assertion? In the first place, Rome had nothing whatever to do with dictating reforms of any kind. Queen Margaret endeavoured to abolish certain abuses that had crept into the Church, owing in great measure to the troubles through which the country was passing. The points with which the Queen concerned herself were: (1) the reluctance of people to communicate on Easter Sunday; (2) marriage with certain near relatives; (3) labour on Sunday; (4) the celebration of the Mass with "barbarous rites." The reader will notice that not one of these matters affected the faith one tittle-they one and all refer to ecclesiastical discipline. It is, therefore, diffi- 
cult to perceive where the "Romanising" enters in.

What St Margaret did find when she came to Scotland and wedded King Malcolm was identity of faith with that which she herself professed. She found throughout the length and breadth of Scotland the same Sacrifice of the Mass, the same sacraments and priesthood, and the same spiritual authority duly acknowledged, to which she was accustomed.

When King David ascended the Scottish throne he found the organisation of the Church based on monastic rather than on more general principles. His idea was to supersede this monastic arrangement by founding territorial dioceses, and by parcelling out such dioceses into limited districts, ternıed parishes.

The older Celtic arrangement had originated in early times, and was essentially missionary in character. It was not a peculiarity of the Celtic Church alone, but it existed of necessity in almost every missionary country.

Rome, with its instinctive preference for order and precision, at a comparatively early date adopted the territorial diocese, and its less important counterpart, the limited parish. 
This Roman organisation was introduced into England, as opportunity afforded, after the advent of St Augustine and his companions, and it was this system which King David initiated in Scotland. Rome had authorised the older, yet less perfect, arrangement because it suited the times, and Rome again sanctioned its abolition when necessity required.

Scandals certainly prevailed in the Scottish Church previous to King David's reign, for in many of the monasteries the office of superior was discharged by a layman, who cared little for the good of souls, so long as money was forthcoming. As a result, the religious houses deteriorated, and the clergy did the same. The fault cannot be laid at the door of the monasteries, but it originated with the introduction of the tribal system into monastic institutions.

Thus was the Church hampered in her work when King David assumed the regal power in Scotland. His measures of amelioration were not aimed at the destruction, much less the annihilation, of Celtic Christianity-that survived, and still survives. What he did was to supplant the ancient order of Church 
government by another, more effectual, and more suited to the altered state of the country. Bishops with dioceses and priests with parishes did not change the ancient faith one iota. Mass went on as heretofore, so did the whole cycle of Catholic doctrine and belief, including the spiritual headship of the Roman Pontiff. The change merely affected external organisation: the same clergy continued in the discharge of their priestly duties, practically unaffected by the sovereign's reforms.

With the sanction of Rome, the first missions were sent to the Celts, and their Church organisation was but the outgrowth of those missions. When the requirements of the time demanded a change Rome organised it, and the same authority regulated the ecclesiastical government of Scotland, under altered conditions, in the sixteenth century.

Moreover, not so many years ago (A.D. 1879), Rome once more intervened and gave back to Scotland her ecclesiastical hierarchy of territorial dioceses. The bishops of these dioceses are not only the sole legitimate possessors of episcopal authority in the kingdom, but they are in perfect continuity with the 
churches founded by St Patrick in Ireland and St Columba in Scotland, because of their identity of faith, and because of their recognition of the claims of the same spiritual authority--the See of Peter.

\section{Conclusion}

Is the foregoing pages it has been shown that the Celtic Church of these kingdoms was both Roman in origin and Roman in its doctrines and essential points of discipline. Moreover, it was "closely bound to the Chair of Peter," as St Columbanus emphatically expresses it. This much-debated "Romanism" has survived to our own day, not in Presbyterianism nor in Episcopalianism, but in that one Church in Scotland whose proud boast it is to be "closely bound to Peter's Chair," and whose full acceptance of papal claims constitutes her the lineal and only representative of the ancient Celtic Church of Scotland. 



\section{N D E X}

Aввотs, lay, 292.

" Ad limina A postolorum," 236.

Adamnan, St, elected Abbot of Iona, 202 ; adopted new Easter and coronal tonsure, 202 ; visited North Ireland, 202.

Engus, Festology of, 106.

African Councils, 82.

Aidan, St, sent to Northumbria, 193 ; attitude towards the Pope, $194,195,196$; introduces fasts in Northumbria, 280.

Ailbe, St, bishop in Ireland, 113.

Altars, consecrated, 272; cloths for, 272.

"Altus Prosator," 152.

Amathorex, Bishop, consecrator of St Patrick, 126.

Amator, Bishop, St Patrick ordained deacon by, 127.

Ambrose, St, and papal claims, $33,61,81$; on St Peter, 34.

American Church (Protestant), Dr Stokes on, 129.

" Anam-chara," soul-friend, 278.

Anatolius, St, his Paschal computation, 174.

Anderdon, Father, S.J., mission from Pope Eleutherius, 95.

Angels and saints, veneration of, 252 ff. ; St Columba and, 254.

Anglican Orders, validity of, 6 .

Anglo-Saxons, Pope Gregory's mission to, $127,156$.

Anicetus, St, Pope, and the Easter question, 55 .

Apostles, the, power "to bind and loose," 20.

Arles, Council of, 98 ; See of, 112.

Armagh, Book of, 99, 122, 139 ; Canon of, 150; Church of and St Celsus, 292.

Athanasius, St, appealed to Pope, 56 ; and Council of Sardica, 99.
Augustine, St, and papal claims, $18,33,34,63$ and note, 82,105 .

Augustine of Canterbury, St, commissioned by Pope Gre. gory, 127, 155 ; and the Britons, $175,177$.

Auxilius, and the Apostolic See, 140.

"Babylon," 36 and note.

Bangor Antiphonary, date of, 230 ; and veneration of saints, 254, 255; and Real Presence, 266.

Bede, Ven., on St Ninian, 102 ; on Irish clergy and monks, 156.

Benedictine Order, and "presbyter-abbots," 211 ; rule and jurisdiction, 212.

Benignus, and Apostolic See, 140.

Bernard, St, and papal authority, 28.

Bible, St Jerome's version, 151.

Bishop, Mr Edmund, on Stowe Missal, 222, 224; on Bobbio Missal, 228.

Blessed bread, used by St Columba, 272.

Bobbio Missal, date of, 227 ; Mr Edmund Bishop on, 228 ; Canon compared with Stowe Canon, 228; prayer in honour of St Peter, 228 ; and Roman Pontiff, 228; and the "Cathedra Petri," 229 ; and veneration of saints, 255; and Lenten fast, 281.

Bollandists, the, 122.

Boniface I., Popc, and papal supremacy, 137.

Boniface IV., Pope, St Colum. banus' letter to, 133. 
Bridgett, Father, on the Stowe Canon, 225 ; on communion in one kind, 269.

Bright, Dr, on relation of Celtic Church to Rome, 163; on St Augustine's conference, 177 ; on Columban obedience, 190 ; on St Aidan, 194.

British Church, Church of St Ninian, 100.

British bishops in papal Councils, $98 . f f$.

Brown, Canon Cowley, on Celtic Church, 187.

Brown, Dr Hume, on Church of Rome, 13.

Brunichilda, Queen, Pope Gregory and, 156.

Bury, Professor, on St Palladius, 116 ; on St Patrick, 127, 141 , note.

Caerleon, on Usk, British archbishop of, 178.

Caledonia, mission to, 95,96 ; migration to, 154, 156.

Calvin, 105.

Candida Casa, 113, 150.

Canons, ancient Irish, 140.

Canterbury, archbishops of, commemorated in Stowe Canon, 227.

Carthage, Council of, 82.

Cassian, Prosper and, 110.

"Catalogus Pontificum Romanorum," 95.

"Cathedra Petri," feast of, 226, 229.

Catherine of Siena, St, and the Pope, 28.

Cathures, St Kentigern at, 144.

Celestine, St, and papal claims, 03, 64, 138; name in Culdee Litany, 96; and Pelagianism in Britain, 109, 110, 115; and St Patrick, 118, 120, 126, 133, 134.

Celsus, St, and Church of Armagh, 292.

Celtic bishops, rule Continental churches, 238.

Celtic monks, not schismatical, 205 ; and Roman Pontiff, 229; as Continental apostles, 238.
Celtic saints, pilgrims to Rome, 234 ; ordained in Rome, 235.

Chalcedon, Council of, 33,82 ; twenty-eighth Canon, 50.

Chapman, Dom. J., 48, note, 51, note.

Chrysologus, St Peter, and papal claims, 81 .

Chrysostom, St John, on supremacy of St Peter, 25, 26, 29, 34,63 ; appealed to Pope Innocent I., 56.

Church, the, an " edifice," "kingdom," " fold," 23.

Church, the mediæval, of Scotland, 292.

Church, the Scottish, reorganised, 296.

Churches consecrated, 272.

Citta Nuova, St Columba's vision of, 152.

Clement of Rome, St, Epistle to Corinthians, 53.

Clerical celibacy, $286 f f . ;$ and marriage contrasted, 288 ; breach of, 289 ; Comncil of Tours and, 289; and St Patrick's ancestors, 290 ; encouraged by St Patrick, 290 ; synodical Canon of St Patrick on, 291.

Colgan, on Irish bishops, 113.

Colman, St, succeeds St Finan, 198; and the Primacy, 200; returns to Ireland, 200.

Columba, St, meeting with St Kentigern, 144; apostolate of, $148 \mathrm{ff}$; ; and Bishop Cronan, 210; commemorates Bishop Colman, 224 ; and the Bobbio Missal, 228 ; his tunic and holy books, 253 ; invocation of, 253 ; and angels and saints, 254 : centenary celebrations of, 267 ; and continuity, 268.

Columban Church, "neither Roman, nor . . . Protestant," 8 .

Columbanus, St, his letters to Popes, 11, 133, 151 ; Skene on, 11 ; belief in papal supremacy, 157 ; and the Pope, $160 f f$; asks for " judicium tuum," 163 ; Irish Church "devineti" to Chair of 
Columbanus, St-contiuned.

Peter, 164; and Church of Jerusalem, 164, note; and papal titles, 166; and Bobbio Missal, 228.

Columkille, the great gem of, 152.

Comgall, St, and St Columba, 161 ; and Bobbio Missal, 228.

Communion, under one kind, 269 ; fasting before, 270 .

Confession, $276 \mathrm{ff}$; practice at Iona, 277.

Confirmation, 282, 283.

Constantinople, Canon of, 12 ; Church of, 49 ; Council of, 85.

Constantius, Emperor, and Church of Britain, 99.

Consubstantial, 84.

Cooper, Professor, on St Kentigern, 146 ; on "Mariolatry" of Celts, 240.

Council of Jerusalem, 25.

Cross venerated at Iona, 261.

Culdee Litany, 96.

Cultus of the Blessed VirginMary, $240 \mathrm{ff}$; Cardinal Newman on, 241.

Cumbria, 102.

Cummian, St, and appeals to Rome, 142 ; Penitential of, 153.

Cyprian, St, and supremacy of St Peter, 32, 34, 47, 60, 80.

Cyril of Jerusalem, St, and St Peter's supremacy, 34.

Cyril of Alexandria, St, on Pope Celestine, 64.

DaGan, Bishop, visits Canterbury and Rome, 179, 227.

Dalriada, King of, 155.

Dalriadans, 154 .

Damasus, St, and papal supremacy, 61 ; and St Ninian, 102; St Jerome and, 105, 113.

Damian; St, sent to Britain by Pope, 94.

Dardania, Bishops of, and Pope Gelasius I., 57.

David, St, Bishop, 145.

David, King, and territorial dioceses, 294.
Dead, prayer for, $263 \mathrm{ft}$; St Columba and, 264 ; St Cummian and, 264; Bobbio Missal and, 264.

Declan, St, Irish bishop, 113.

Decretals, Isidorian, 51.

Derry, 152.

"Dicta Patritii," 132.

Dinoth, Abbot, and Roman supremacy, 176.

Dionysius, St, and papal supremacy, 56.

Dionysius, Scottish missionary, 95.

Dionysius Exiguus, and Paschal computation, 173.

Dioscorus, and Council of Chalcedon, 33.

Divinity of Christ and of the Holy Ghost, 83.

Döllinger, $\mathrm{Dr}$, on power of keys, 21 ; on Celtic controversy, 204.

Donald, King, and Pope St Victor, 95.

Dowden, Dr, mediæval Church and Rome, 103.

Duchesne, Mgr., on Gallican Liturgy, 219; on Stowe Missal, 222.

Easter controvirsy, 98, $173 \mathrm{ff}$., $202,203,204$.

Egbert, St, induces Iona to conform, 202.

Eileran, St, his Life of Patrick, 134.

Eleutherius, St, sends missionaries to Britain, 94, 96.

EIvan, sent by Lucius to Pope, 93.

Ephesus, Council of, 33; See of, 54.

Episcopacy at Lindisfarne, 213.

Episcopal consecration of Irish monks, 213.

Eric of Auxerre, on St Germanus, 135.

Eucharist, the Holy, $265 \mathrm{ff}$; ; unleavened bread used for, 271 ; water mingled with wine for, 271.

Evangelise, obligation to, 155.

Ex-cathedra decisions, $75,78,85$, 86. 
Exorcisms, 273.

Extreme Unction, 284.

Fasting, before Communion, 270 ; as penance, $279 \mathrm{ff}$; ; at Iona, 280.

Feasts and their Octaves in Celtic Church, 273.

Felix, St, and the Celtic mission. aries, 196.

Fiacc, St, his hymn, 122.

Finan, St, and St Wilfrid, 197.

Finnian of Moville, St, at monastic school in Galloway, 107; and the Pope, 150, 151 .

Forbes, Dr, on Culdee Litany, 96.

Fordun, on mission from Pope St Victor, 95 ; on Palladius, 116.

Fowler, Dr, on Columban Church, 5.

Fugatius, St, sent to Britain by Pope, 94.

Galileo, 85.

Galloway, St Ninian settles there, 104, 107.

Gaul, Bishops of, and Pope, 65 ; and St Columbanus, 239.

Gaul, Church of, and See of Rome, 111.

Gelasius I., St, Epistle to Bishops of Dardania, 57.

Gencreus, Saxon monk of Iona, 156.

Genuflecting, 273.

Germanus, St, mission to Britain, $109,110,114,115$; and $\mathrm{St}$ Patrick, 121, 123, 134.

Gildas the Briton, 151 ; on papal authority in Britain, 176.

Glasgow, 144, 145.

Gore, Dr, on papal supremacy, 48.

Grampians, the, not the limit of St Ninian's work, 166.

Greek schism, 130.

Gregory Nazianzen, St, on primacy of St Petcr, 32.

Gregory the Great, St, mission of St Augustine, 127, 155; and St Kentigern, 146 ; and St Columbanus, 151, 152; on conversion of hesthen, 195.
Gregorian Calendar in Great Britain, 184, 203.

Haddan and Stubrs, on mission from Pope Eleutherius, 95; on Canon of St Patrick, 141.

Harnack, Professor, on St Cyprian's "De unitate," 48 , note ; on St Irenæus, propter potentiorem principalitatem, 60 , note.

Healy, Archbishop of Tuam, on St Patrick, 135.

Hedley, Bishop, on infallibility, 70.

Hibernia, and St Ninian, 106 ; and Palladius, 116.

Hilary of Poitiers, St, on primacy of St Peter, 32; and papal supremacy, 60 .

Hilary, Pope, and papal supremacy, 66 .

Hogan, Father Edmund, S.J., and Book of Armagh, 122.

Honorius, Pope, and papal infallibility, 85, and St Patrick, 131 ; Epistle to Irish bishops, 180; and southern Ireland, 187.

Honorius of Canterbury and the Celtic missionaries, 195.

Hormisdas, Pope, formula of, 66, 80.

Hours, canonical, 273.

Hy, Abbot of, his jurisdiction, 160.

IвAR, ST, Irish bishop, 113.

Ignatius, St, and papal supremacy, 59.

Images, sacred, in Old Testament, 261 ; Cross venerated at Iona, 261 ; Ccltic pictures of our Lady, 262.

Infallibility, papal, $68 f f$; and Scripture, $76 \mathrm{fl}$; witness of tradition to, $79 f f$; objections to, $84 f$.

Innocent I. St, and papal supremacy, 56, 63, 115; and papal infallibility, 82; and appeals to Rome, 100, note, 108.

Inspiration, individual, 73. 
Iona, messengers to from Pope, 152; grant of to St Columba, 155.

Irenæus, St, and papal supremacy, 53, 54, note, 59, 94, 111 ; and papal infallibility, 80 .

Irish Church, and papal suprem. acy, 129, $137 f f$.

Irish prelates, letter to from Canterbury, 178; obedience to Rome, 191.

Irish saints, first order of, 147.

Irish schools, Continental students at, 237.

"Italian Mission," 104.

Ivrea, Church of, 126.

Jerome, ST, on primacy of $\mathrm{St}$ Peter, 35; and papal supremacy, 62,63 , note, 105 ; and papal infallibility, 81; St Ninian's master, 102, 104; on relics, 257.

Jocelin of Furness, Abbot, and St Kentigern, 144, 146.

John IV., Pope-elect, 189 ; answer to Irish prelates, 189.

Julius II., Pope, St Athanasius appealed to, 56 ; and Council of Sardica, 100.

KentigerN, ST, apostolate of, 144 ff; pilgrimages of, 145 ; bell of, 146

"Keys," signification of, 20.

Kieran, St, Irish bishop, 113.

Kintyre, and St Columba, 153.

Knox, his teaching and Celtic Christianity, 105, 149.

LATIN, reason for use of, 232 ; terms used by Celts, 232.

Lawrence of Canterbury, St, succeeds Augustine, 178; his letter to British bishops, 178.

Lebar Breac, 134.

Ledwich, Dr, on St Patrick, 117 ; on St Columba, 148

Legetius, and St Patrick, 135.

Lent at Iona, 280.

Leo the Great, St, and papal supremacy, $23,48,57,64,112$; and St Patrick, 128, 134, 138.
Leoghaire, and St Patrick, 134.

"Lex credendi, lex orandi," 217 , 226, 229.

Liber Antiphonarius, to St Columba, 152.

Liberius, Pope, and papal infallibility, 84.

Lightfoot, Dr, on Celtic Christianity, 7,148 ; on St Clement's Epistle, 53; on Roman and Celtic missionaries, 195.

Lindisfarne, Gaul and Rome, 197 ; episcopacy, 213.

Lingard, Dr, and papal missions from Gaul, 110.

Liturgy, origins of, 217 ; Eastern and Western, 218; Roman and Gallican, 218; Gallican, 219; Milanese, 219; Roman, 219; Scoto-Celtic, 220; of Irish saints, 220; Lanigan on, 221 ; of St Patrick, 221; Celtic and papal supremacy, 222 ; language of, $231 \not t$.

Llandaff, and early missions from Rome, 94.

Lucius, King, and early missions from Rome, 93, 94.

Lupus, St, and papal missions from Gaul, 109, 114.

Luther, his teaching and Celtic Christianity, 105.

MacCarthy, Bifessed Thaddeus, body at Ivrea, 126.

MacCarthy, Dr, on Stowe Missal, 223 ; on Stowe Canon, 225.

Maclruen, name in Stowe Missal, 223.

Magh-lene, Synod of, 142.

Marcus, Scottish missionary, 95.

Margaret, St, and Church reform, 293.

Martin of Tours, St, and St Hilary, 32; name in Culdee Litany, 96.

Martin II., Pope, and Council of Rome, 82.

Mary, the Blessed Virgin, Mother of God, 64, 247; cultus of, $240 . t$; Card. Newman on, 241 ; 
Mary, the Blessed Virgin-cont. devotion of southern nations to, 242 ; in missal and breviary, 243 ; devotion to her test of orthodoxy, 244; nature of Catholic devotion to, 245; St Irenæus on, 245 ; St Justin Martyr on, 246 ; Tertullian on, 246; St Jerome on, 246 ; Council of Ephesus and, 247; devotion to in Celtic Church, 247; devotion to in Church of Gaul, 247 ; first feast of, 248 ; perpetual virginity of, 248 ; in Stowe and Bobbio Missals, 249; Celtic Litany of, 249 ; consecration to, 250 ; holy wells and churches bearing her name, 251 ; Celtic pictures of, 262.

Mass in Columban Church, 224 ; names for, 266 ; vestments used, 271 ; lighted candles used, 271 ; incense used, 271.

Medwin, sent to Pope, 93, 94.

Merry del Val, on papal suprem. acy, 41.

Milevis, Council of, 63, 82.

Missions, from Rome, $93, f$. ; papal, from Gaul, 108 ff.

Muirchu - Maccu-Mactheni, 121, 122.

Moclcaich the Scribe, 223.

Monks of Iona and disobedience, 188.

Moran, Cardinal, on latinity of St Patrick, 121.

Mungo, St, 144.

Munis, sent by St Patrick to Rome, 134.

Nectan, Kino, and Celtic monks, 203 , note.

Newman, Cardinal, on papal supremacy, 45; on papal infalli. lility, 73.

Nicrea, Council of, 83, 99.

Ninian, St, and Rome, 61, 62 ; his mission, $102 f f$. ; his influence in Ireland, 113.

Northern Picts, conrersion of, 154.
O'Hanlon, Canon, on St Patrick, 125 , note.

Old Leighlan, Council at, 180.

Orders and jurisdiction in Celtic Church, 210.

Origen, on primacy of St Peter, $32,33$.

Oswald, St, asks help from Iona, 193.

Oswy, King, requests conference, 198.

Paliadius, ST, mission of, 63, 96, $110,113,114,115,116,127$.

Palms, blessing of, 273.

Paschal controversy, 173 ff.; Celtic computation, 174 ; Roman computation adopted in Sonth Ireland, 181 ; Epistle of St Cummian, 183; in North Ireland and Iona, 189 ff ; false impressions in Rome, 190 ; reason for monks' persistency, 203.

Patrick, St, and papal supremacy, $64,81,96$; Roman mission of, 117. ff.; his confession, 118 ; “Tripartite Life," of, 126 ; evidence for his Roman mission, 129 ff.; decree concerning Rome, $181,186,189$; imbibes papal doctrine in Gaul, 182; and St Peter, 230; fasts of, 280.

Paul of Samosata, excommunicatied by Pope, 56.

Paulinus, St, and Northumbria, 193.

Pelagius, Pope, and Finnian, 150.

Penance and fasting, $279 . \mathrm{ff}$; reasons for, 579.

"Per unitatem fidei," 162.

Peter, St, "primus inter pares," 21 ; primacy of honour, 2l ; commission to, 22 ; his suprem. acy in Apostolie Age, $24 \mathrm{Jf}$; objections to his supremaey, $27 f f$; patristic testimony to his supremacy, $31 f f$; the key.bearer, 33 ; the chief pastor, 34 ; first Bishop of Rome, $36 f f$; feast of Chair, 38; "closely bound to Chair of," 159 ; prayer to in Stowe Missal, 225. 
Pilgrimages to Rome,Celtic, 234. $f \circ$; their object, 236.

Piln, Saxon monk of Iona, 156.

Politics, the Pope and, 89.

Polycarp, St, and Easter question, 55.

Poljcrates, and Easter question, 55.

Presbyter-abbot, 209 ff.

"Primus," Scottish, and Celtic Church, 130.

Probus, his Life of St Patrick, 124.

"Propter potentiorem principali. tatem," 59.

Prosper, on papal mission from Gaul, 109, 111, 114.

Prostrating, 273.

Protestant Pope, 130.

Psalter, Latin, 151.

Puller, Rev. F. W., on St Cyprian, 47.

Real Presence, Bangor Antiphonary and, 266; and Peni. tential of St Columbanus, 267.

Relics, holy, of SS. Peter and Paul, 128; Zimmer on, 256 ; Council of Trent on, 257 ; St Jerome on, 257 ; Scripture evidence for, 258; of St Columba, 258; of St Patrick, 259; and miracles in Ireland, 259; of St Aidan, 259 ; St Columbanus on, 260.

Rivington, Dr, on papal supremacy, 52.

"Rock," St Peter the, 18, 32.

Romans, Church of the, and Chureh of the Irish, 132 .

Rome, Bishops of, 38 ; Council of, 49, 82 ; Church at, 59 ; Church of, 141; head of all cities, 158 ; pilgrimages to, 234 .

Ronan, and St Finan, 197.

Rufinus, St Jerome and, 81 .

Rufus, Bishop, and Pope Boniface I., 137.

SabrluiUs, heresy of, 56.

Sacrament, Blessed, bowing to, 270 ; reservation of, 270 .

Satyrus, St Ambrose and, 81.
Scandals in Scottish Church, 295.

Sechnall, St, hymn of, 121, 230.

Secundinus, and St Patrick, 140.

Segenus, Abbot, and his com. munity, 183; superior of St Aidan, 183; his name among Irish prelates, 191.

Servanus, St, name in Culdee Litany, 96.

Severinus, Pope, Irish prelates appeal to, 189.

Severus of Treves, and papal mission from Gaul, 110.

Sign of the Cross, 274.

Siricius, St, ordained St Ninian, $62,102,106,118$.

Sixtus, Pope, in Lebar Breac, 134.

Skene, Dr W. F., on early Church of Scotland and Ireland, 9, 10 ; on St Jerome, 62 ; on St Columba, 151.

Smith, Dr, on monks of Iona and See of Rome, 5.

Socrates, on action of Pope towards Athanasius, 56.

Soter, St, Pope, and Bishop of Corinth, 54.

Spain, and St Columba, 158 ; Celtic colony in, 158, note.

Stokes, Dr G. T., on St Patrick's Roman mission, 129.

Stokes, Dr Whitley, on sayings of St Patrick, 132; on Canon of St Patrick, 141.

Stowe Missal, Mgr. Duchesne and Mr Edmund Bishop on, 222 ; Dr MacCarthy on, 223, 225; and Roman Pontiff, 225.

Strathclyde, St Kentigern in, 144 ; Church in, 147.

Striking breast, 273.

Supremacy, papal, witness of New Testament to, 14 ; need of, 15 ; result of, 15; testimony of history and Fathers to, 43 ff., 59 ff.; objections to, $47 \mathrm{ff}$.; exercise of, $53 f f$; and Irish Church, $137 \mathrm{ff}$; in Iona, 187 ; and Celtic Liturgy, $222 \mathrm{ff}$.

Suprẻmacy of St Peter, $17 \not t$.

Supremacy of St Peter's successors, $40 \mathrm{ff}$. 
Sylvester, St, Pope, and British bishops, 98.

Tarragona, Bishops of, and Pope Hilary, 66.

Temporal power of Pope, $87 . t f$.

Tertullian, and St Peter at Rome, 38 ; and Christianity in Britain, 95.

Theodebert, King, and papal mission, 156.

Theodoret, Bishop of Cyrus, appealed to Pope, 57.

Theodoric, King, and papal mission, 156.

Thomas Aquinas, St, on primacy of St Peter, 27.

Thomas of Canterbury, St, reproved Pope, 28.

Tirachan, St, and Book of Armagh, 133.

Todd, Dr, on Roman Mission of St Patrick, 120, 129, 141.

Tonsure, St Wilfrid and, 206 ; Celtic origin of, 207 ; a nonessential, 207.

Tradition, Celtic, 131.

"Transubstantiation," 265.

Ulifathorne, Archishop, on St Patrick, 126.

Ulster, annals of, 134.

Ultan, St, his Life of St Patrick, 133.
“ Unitas Catholica,"179,note, 180.

Unity and uniformity, $169 . f f$.

Ussher, Dr, on ancient Celtic Christians, 5; on St Palladius, 113.

VATICAN, Council of, 69, 126.

Victor, St, Pope, and papal supremacy, 55; and early missions from Rome, 95, 96 .

Victorious of Aquitaine, his Paschal computation, 173.

Victricius of Rouen, St, and Pelagianism in Britain, 109.

WARREN, on Stowe Missal, 222.

Water, holy, used in Celtic Church, 272.

Westall, A. St Leger, on twentyeighth Canon of Chalcedon, 50 , note.

Whitby conference, $197 \mathrm{ft}$.

"Whitewashed wall," 180 .

Wilfrid, St, and Roman Council, 171, 205, note; and St Finan, 197; on Paschal question, 199; and tonsure, 206.

Wynnin, St, his visit to Rome, 145 .

Zimmer, Dr, on St Patrick, 117 ; on excommunication, 184 ; on holy relics, 256. 
THE RIVERSIDE PRESS LIMITED, EDINBURGH 

University of Callfomia

SOUTHERN REGIONAL LIBRARY FACILITY

405 Hilgard Avenue, Los Angeles, CA 90024-1388

Return this material to the library

from which it was borrowed. 
UC SOUTHEAN REGIONAL LIBRARY FACILITY

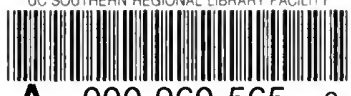

A 0009605650 


\section{(I)}

